\title{
THE SALVATION ARMY
}

Afghan Refugee Assistance Project PAKISTAN

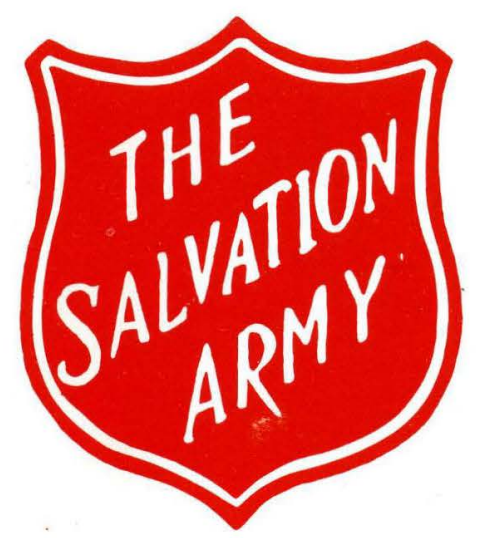

\section{FINAL REPORT \\ PROJECT PD - 734 (III)}

PERIOD 1ST MAY 1990 - 30TH APRIL 1991

MEDICAL PROGRAMME 
THE SALVATION ARHAY

Afghan Refugee Assistance Project

PAKISTAN

\section{THE SALVATION ARMY}

APGHAN REF'UGEE' ASSIST'ANCE' PROJEC'I'

\section{PAKISTAN}

FINAL REPORT

PROJECT PD - 734 (III)

PERIOD $15 T$ MAY 1990 - 30TH APRIL 1991

MEDICAL PROGPAMME 


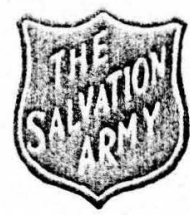

THE SALVETIUK ARHY

Afghan Refugee Assistance Project

PAKISTAN

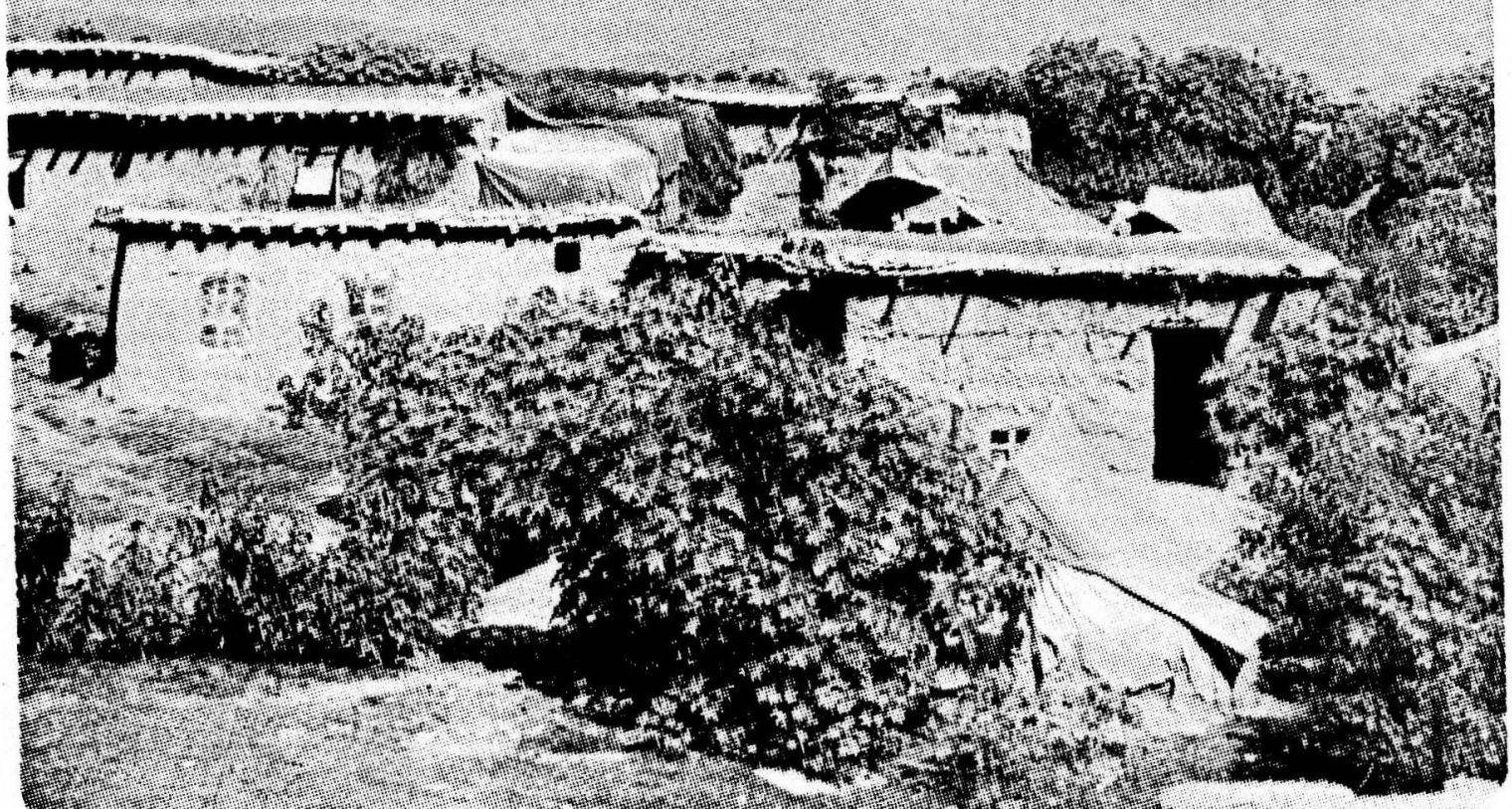

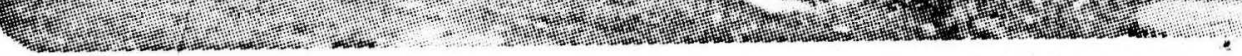

Part of the Haripur refugee camp.

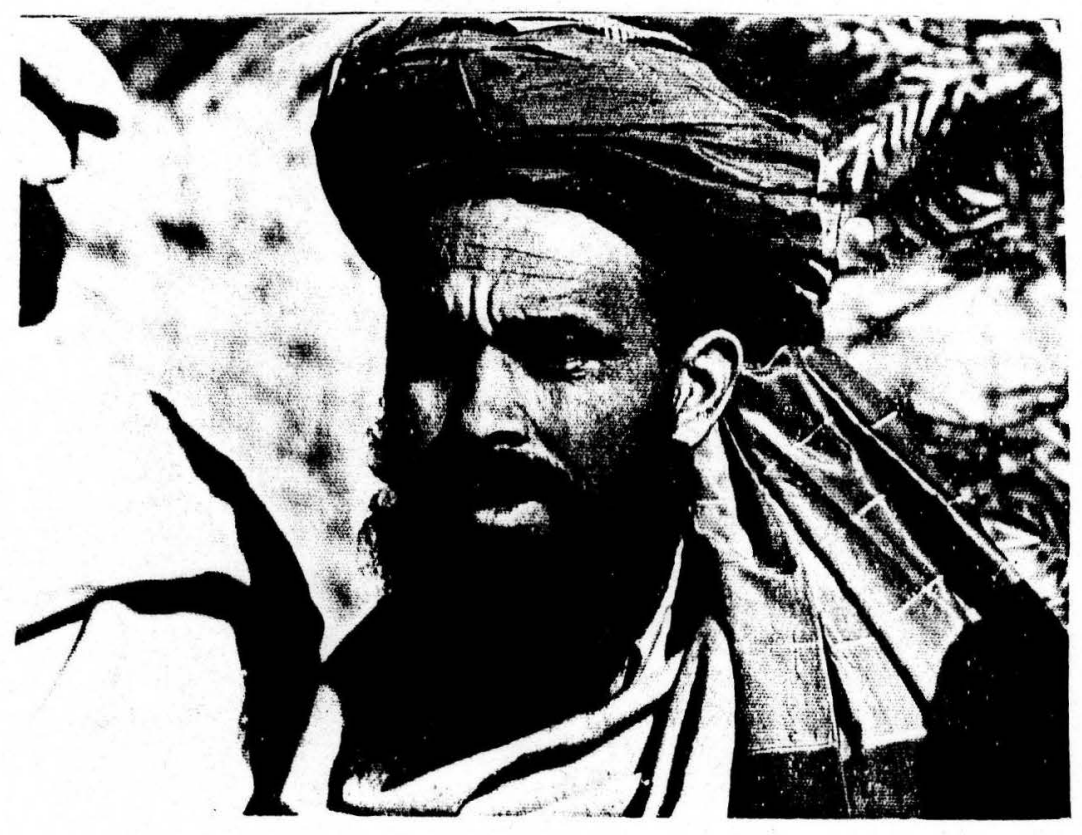

What
does the
future
hold?




\section{LIST OF CONTENTS}

Page No.

EXECUTIVE SUMMARY

ACKNOWLEDGMENT

BACKGROUND

BASIC MEDICAL PROGRAMME - OPERATIONAL DETAILS 14

ADMINISTRATION AND FINANCE

FUTURE PLANNING

ANNEXES 


\section{THE SALVATION ARMY \\ Afghan Refugee Assistance Project \\ PAKISTAN}

\section{EXECUTIVE SUMMARY}

It is with mixed feelings that I introduce this Final Report on the Medical Programmes implemented by The Salvation Army Afghan Refugee Assistance Project. This is a Final Report not only due to the end of the current grant but also because the Medical programmes were transferred to Save the Children Federation of the U.S.A (SCF(US)) as at close of work on 30th April 1991.

\section{TRANSFER}

When one considers that in transferring this programme, 147 staff with a total of $\mathbf{4 9 2}$ years of service are involved, it is sad to see these staff leave The Salvation Army employment but it is good to know that another organisation has re - employed them and is now running the medical programme which these staff developed.

Here some explanation of the reason for this transfer may be helpful. The Salvation Army is working in 93 countries at present and in each of these, we have the approval of the Government to conduct our activities. In view of the unstable political situation and the lack of a totally representative Government in Kabul, it was decided that the Army could not commence work in Afghanistan.

This fact led to the formulation of a plan of activity which detailed the staged withdrawal of The Salvation Army from the refugee situation. It was a major consideration that the care of the refugees must not suffer during this process and it was decided that the medical programme should be transferred to an International agency who could maintain its high standard and attract donor funding. The Vocational Training and Income Generation programmes were to be transferred to an Afghan Non - Governmental Organisation (ANGO), created from within the project.

As the first step in this plan, the Afghan Development Association (ADA) was formally created on 31st October 1990 from the staff of the vocational training and income generation project. $A D A$ is already implementing a project in Afghanistan and has other project proposals with donors awaiting funding. From 1st November 1991 the third step will be complete when ADA will commence implementation of the EEC funded vocational training and income generation project with EEC funding being passed through The Salvation Army. 
The second step has been the transferring of the medical programme to SCF(US) as at 30th April 1991. This transfer has been effected with the full prior approval of the donor, the U.S State Department Bureau for Refugee Programs, who have funded the programme through the Salvation Army World Service Office in Washington D.C for nine years and State Department are now funding SCF(US) for this programme.

It will be of interest to our readers to know that the medical programme has been transferred to SCF (US) at the same level as it was being implemented by The Salvation Army. A total of 147 staff members with 492 years of service have been transferred together with major assets worth Rs.1,899,612.00 (Purchase Value) and all related contents of the field offices and hostels at Haripur and Ghazi. All the contents of the six BHUs that were being used in the smooth implementation of the Medical Programme have also been transferred to SCF(US).

The SCF(US) have advised us that they will continue the programme at it's present level and will make no major programme changes without prior reference to the U.S State Department. We appreciate this comment.

The final step will be the conclusion of the provision of technical assistance to ADA by The Salvation Army. Peshawar in early 1992, by which time ADA will have all the skills for successful project implementation.

This report deals in detail with all the achievements accomplished during the reporting period on the medical programme and also the role of the administration regarding the transfer of the Medical Programme to SCF(U.S).

\section{THE REFUGEES}

Some background information is necessary to be able to view the work of this project in context. As mentioned in our previous interim report dated January 1991, the conflict in Afghanistan is still unresolved and Pakistan is still hosting 3.2 million refugees. More refugees have come in and according to Government of Pakistan and UNHCR reports, a total of 10728 new refugees arrived after the battle of Khost (Afghanistan) during the months of March and April 1991.

As assistance to the refugees continues to decline - shown by reductions in the food rations and in the increased difficulty in receiving 


\section{THE SALVATION ARMY \\ Afghan Refugee Assistance Project \\ PAKISTAN}

donor funding for any work in Pakistan related to the Afghans - it is noteworthy that U.S State Department has continued its funding to this project at a high level.

The increase in refugees worldwide has affected the Afghan Refugees budget of the United Nations High Commissioner for Refugees (UNHCR), and according to reports from the press, UNHCR and the Agency Co-ordinating Body for Afghan Relief (ACBAR), the UNHCR budget has been reduced by $20 \%$ to U.S $\$ 32.4$ million for 1991 . This loosely represents U.S $\$ 10$ per refugee for the year, further decreased by overheads and administration costs.

There is also a growing concern among the refugees that the general reduction in assistance could be used as a weapon to encourage them to return to Afghanistan.

Some donors are not willing to release further funds until there is evidence of a repatriation. This can tend to further complicate the situation for the refugees and at the same time, the Government of Pakistan's Afghan Refugee Commissionerate through which all the refugee camps are being administered, has released about 2000 workers in different grades due to lack of funds.

\section{A POLITICAL SETTLEMENT}

These difficulties have to be set against the backdrop of the work being done to find a political settlement to this conflict. Mr.Benon Sevan, Personal Representative of the Secretary General of the United Nations relating to Afghanistan is still working on a plan to bring peace and stability to Afghanistan.

Mr.Sevan has spoken to all the interested and involved parties and Governments and for three years has been attempting to convince all the players that a political and not a military solution is necessary. Here in Peshawar there is much talk of a solution being near. There does seem to be more desire on the part of the refugees to be able to go back but this desire has not been strong enough to commence a repatriation due to the present difficulties in Afghanistan.

\section{REPATRIATION}

Before any repatriation however, much work needs to be undertaken in Afghanistan. There is a total of 636,000 square kilometers of 


\section{THE SALVATION ARMY \\ Afghan Refugee Assistance Project}

minefield in Afghanistan (Mines Advisory Group Report 1991) most of these uncharted, and although there are many courageous de - miners at work clearing these, much more is necessary.

There is still a lack of willingness on the part of many donors to fund rehabilitation and development projects in Afghanistan, which could encourage repatriation. On one hand, due to war and difficulty in monitoring levaluation, this can be understood but on the other hand, the destruction caused by war and neglect over the past 11 years calls for a very large and sustainable donor effort.

\section{INTEGRATED RURAL DEVELOPMENT}

Both donors and Non - Governmental Organisations (NGOs) and Private Voluntary Agencies (PVOs) need to commence integrated rural development projects, either implemented by themselves or in close partnership with other agencies. Donors need to be willing to fund these ventures for longer than the traditional aid funding period of 1 year. These efforts should then produce a more habitable Afghanistan. ACBAR, the Coordinator for UN Humanitarian and Economic Assistance Programmes Relating to Afghanistan (UNOCA) and the donors need to formulate plans to implement this approach.

Funding problems did affect The Salvation Army's vocational training and income generation project for most of 1990 but now due to timely acceptance of funding proposals by Inter Church $\mathrm{Co}$ - ordination Committee for Development Projects (ICCO) of the Netherlands and the European Community (EC), this project is now able to continue.

\section{THE MEDICAL PROGRAMME}

The Medical Programme here reported did not suffer any funding difficulties due to the kind assistance of U.S State Department.

As alluded to earlier, some concern is expressed about the standard of health of the refugees, particularly with a reduction in aid.

One effect of this noticed by the project is the increase in Plasmodium Falciparam or Cerebral Malaria. The number of cases during this project year was 327 while during the last two years i.e in 1988 - 89 and 1989 - 90 was 211 and 157 respectively. One theory could be that the staff are more efficient, while this would be nice to think - and may 


\section{THE SALVATIOH ARMY \\ Afghan Refugee Assistance Project \\ PAKISTAN}

be true - the staff feel that this is due to lack of spraying of an anti larvae insecticide (see Malaria Control Programme for further details).

Despite more efforts on preventive health (of 170,653 attendances at the BHUs, $87 \%$ received health education by one of the BHU staff) the number of diarrhoea cases has shown a sharp increase from 6944 in 1988 - 89 to 8681 in $1990-91$. This could be due to a number of reasons which the project has not been able to investigate, but a possible reason for this increase could be the number of pit latrines destroyed $(40 \%-50 \%)$ during the current period due to heavy rains.

The project managed to immunize approximately $95 \%$ of the total under two population during the last and the current project period. Yet another achievement of the project was to register $89 \%$ of the 3200 pregnant women in the camps at a given time in the Ante Natal clinic. Similarly $71 \%$ of 2065 deliveries recorded in the camps were assisted by one of our health team staff.

\section{AFGHAN DEVELOPMENT ASSOCIATION}

During the current period. The Salvation Army has established an indigenous Afghan N.G.O. named Afghan Development Association (A.D.A.) which has now started implementing cross - border projects and recently distributed seeds and fertilizer among the residents of Said Abad district in Wardak Province of Afghanistan.

The 10 metric tonnes of Pak 81 seed and the same amount of fertilizer were provided by the Food and Agriculture Organisation of the United Nations (FAO) and the administrative costs were provided by the Canadian Local Initatives Fund for Afghanistan (CIDA) in Islamabad. For future projects in Afghanistan, proposals have been submitted by ADA to different prospective donors and it is hoped that funding will be made available for these projects.

A survey project is being conducted by ADA in Uruzgan, northern Kandahar and south western Zabul provinces. This will enable ADA to prepare integrated rural development projects for submission to donors.

\section{CONCLUSION}

This report details the work and achievements of The Salvation Army project. It is a small contribution to this large need but non the less, 


\section{THE SALVATIOM ARMY \\ Afghan Refugee Assistance Project \\ PAKISTAN}

has been a significant contribution. However, without our staff and without funding, no work would have been possible.

Thank you to our staff and the donor.

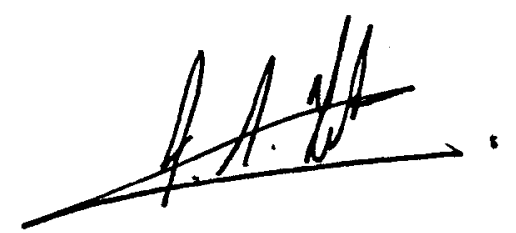

Captain Ivor S.Telfer, Director.

Peshawar, June 1991. 


\author{
THE SALVATION ARMY \\ Afghan Refugee Assistance Project \\ PAKISTAN
}

\title{
ACKNOWLEDGMENI
}

The Project Management wish to thank all those who were involved directly or indirectly in various stages of planning, implementation and development of this programme. You helped, assisted and guided the programme to make it one of the most successful medical programmes to be implemented by a voluntary agency among the Afghan Refugees in the N.W.F.P.

\section{THE DONOR}

Firstly, the Project Management extend sincere thanks to the U.S. State Department Bureau for Refugee Programs, the major donors of this programme, for their continued funding support over the last nine years. This support enabled the project to provide continuous assistance to a total of 80,000 Afghan Refugees residing in Haripur and Ghazi refugee camps. Without U.S. State Department's assistance and funding, the project would not have existed.

It is important to note that including this grant, this was the ninth consecutive grant from the Bureau for Refugee Programmes of the U.S. State Department, through The Salvation Army World Service Office (SAWSO) in Washington D.C.

\section{S.A.W.S.O}

The Project Management also sincerely thank the staff members at The Salvation Army World Service Office (SAWSO). Washington, namely Mr.Dean B.Seiler the Executive Director, Mrs.Joan Robinson Assistant Executive Director, the (Late) John Wiggins, the (Late) Doug Hill, Mrs.Dian Svendsen and Mr.Randy Gibson, SAWSO Project Officers for Asia. You not only helped in securing funds to continue our activities among the refugees by representing this project in the best possible way at Capitol Hill, but also provided continued technical assistance and advice to improve the quality of the services for the refugees through this project.

Also sincere thanks go to Ms. Rani Parker of SAWSO who gave further assistance during the last few months of this project. 


\section{THE SALVATION ARMY \\ Afghan Refugee Assistance Project \\ PAKISTAN}

\section{THE SALVATION ARMY}

We would also like to register our thanks to Lt. Colonel John Swinfen, Director, Development Services Department at The Salvation Army International Headquarters in London and his staff in general for their untiring efforts to publicise the project's work and to raise funds for the project.

We would also like to register our sincere thanks to Commissioner Holland ( $R$ ), Colonel Gordon Bevan (R) and Commissioner John Nelson, who were the Territorial Commanders at The Salvation Army Territorial Headquarters Lahore, being responsible for the Army's refugee work during the grant periods.

Also thanks go to Major Peter Clack and Major Margaret Castley the Financial Secretaries for their support and advice on financial matters, which helped this project to assume its present shape.

We would also like to thank Sister Sue Allibone and Capt. Irene Ogilvie who, in the initial stages of the development of this project, provided technical assistance.

\section{THE DIRECTORS}

Our sincere thanks must also be recorded to the previous Director of this project namely Major and Mrs. David J.Burrows, who established this project between 1982 and 1985 and was still responsible for this project as Social Secretary between 1985 and 1989. Sincere thanks also go to the Field Programme Co-ordinator Mr. and Mrs. Wim Kanis who developed and expanded this project from 1986 to 1988. Also we would like to thank the present Director Captain and Mrs.Ivor S.Telfer, who from 1988, have contributed towards the institutional development as well as towards the conclusion of this project and worked tirelessly to prepare the ground for the smooth transfer of the medical programme.

Special mention should be made about the wives of the senior staff, Mrs.Major Burrows, Mrs.Kanis and Mrs.Captain Telfer, all of whom capably combined roles of mother and Primary Health Care Advisor, spending time on the female related aspects of the programme. All these people made continuous efforts to make this project a real success. 


\section{THE SALVATIOH ARMY \\ Afghan Refugee Assistance Project \\ PAKISTAN}

THE STAFF

Taking this opportunity, we would also like to register our thanks to former Project Management staff namely, Dr.Qamar Uz Zaman who was involved in establishing the Ghazi medical programme. Mrs.Gill Biland who looked after all the finances, Mr.Abdul Ghaffar Masoom Programme Officer Health Education, Dr.lbrahim Shah who ran Ghazi Programme for two years, Dr. Zainul Abedin who ran the Ghazi programme from 1989 to the handover and Dr.Abdul Wahab who ran the Haripur programme from 1986 to the handover. The Salvation Army recognises their contribution and efforts in making the programme a success.

Finally, we would like to thank the Project Accountant, Mr.Abid Shehzad and Manager Administration, Mr.Syed Mehmood Asghar who contributed much in the development of the financial and administrative systems and procedures, Mr.Mehmood also looking after the Haripur Medical Programme for eight months during Dr.Wahab's absence. Captain Telfer also records his special appreciations to Mr.Abid and Mr.Mehmood for their invaluable assistance in preparation for and assisting in the smooth transfer of assets and programme to SCF(US).

Last but not least, we would sincerely like to thank the most important assets and the strength of our project, 147 staff members with a total of 492 years of service, including Medical Officers, Dispensers, Lady Health Visitors, Nursing Assistants, Dai Nurses, Vaccinators, Malaria Supervisors, Sanitarians, Drivers, Guards, Record Clerks, Traditional Birth Attendants, Community Health Supervisors and Female Health Supervisors who have contributed tremendously in achieving the project goals and objectives. It was due to their dedication and willingness to work in difficult conditions and extreme heat that, although often faced with many constraints in the field, they have always managed to perform their duties to a high standard. The Salvation Army will not forget their contribution to this project.

\section{THE GOVERNMENT OF PAKISTAN}

The Salvation Army would also like to thank the Commissioner for Afghan Refugees of the Government of Pakistan, Office of the Project Director Health for Afghan Refugees, Deputy Directors T.B Control, E.P.I, M.C.H and Malaria Control Programme, the F.S.M.O and the District Administrator Afghan Refugees for their continued assistance 


\section{THE SALVATION ARMY \\ Afghan Refugee Assistance Project

and support at their respective levels in the smooth running of the medical programme. Also thanks go to United Nations High Commissioner for Refugees (UNHCR) personnel for their assistance.

\section{OTHER AGENCIES}

We would also like to thank all those voluntary agencies working for the welfare of the Afghan Refugees, who have assisted and helped us in the training of our staff. We would especially like to thank Italian Cooperation for Development (I.C.D) for their kind assistance in implementing the T.B control programme through the provision of training, medicines and other related supplies for the laboratory.

\section{IN CONCLUSION}

We hope we have not missed out anyone in our thanks. If we have please forgive us and a special thanks to you. We would like to thank all those who were involved in the preparation of this report and all those who have contributed by offering their comments and advice in the formulation of this report.

The Management look forward to receiving valued comments from the readers of this report. 


\section{THE SALVATIOM ARMY \\ Afghan Refugee Assistance Project

\section{BACKGROUND}

Today, Pakistan is hosting 3.2 million Afghan Refugees, which constitute the single largest refugee population in the world.

These refugees are residing in 338 camps in 25 districts and tribal agencies of Pakistan. Most of these refugees live in the North West Frontier (68\%), Baluchistan (26\%), and Punjab (5\%) provinces. The remainder are scattered elsewhere in the country.

The majority of the refugees are pathan tribesmen, primarily from Afghanistan's eastern regions, a small number are Baluchi's, Hazara's, Nuristani's and Turkmen. Out of the total refugee population residing in Pakistan, $51 \%$ of them are children, $26 \%$ are women and $22 \%$ are men.

The Salvation Army commenced its operation by setting up two Basic Health Units (BHUs) in Ghazi camps in August 1982. Since then, The Salvation Army has been providing Medical Services, and later also Community Health Education (Male and Female), Vocational Training and Income Generating activities to an estimated 80,000 refugees residing in seven tented villages in the Hazara Division of the N.W.F.P. The two locations in the N.W.F.P are Ghazi and Haripur, approximately 120 and 160 k.ms east of Peshawar.

The funding for the Medical Programme was being provided by the U.S. State Department Bureau for Refugee programmes (USSD), for the Community Health Education programme by Canadian International Development Agency (CIDA) and The Salvation Army, Canada and Bermuda Territory (SAC\&B), for Vocational Training and Income Generation jointly by Inter Church Coordination Committee for Development Projects (ICCO) of The Netherlands, the European Community (EC), the project's Leatherwork Income Account (LWI) and the Food Preservation programme by STICHTING VLUCHTELING (SV) of the Netherlands. The following chart details the approximate budget size at 30th April 1991.

For the current project period, a proposal for a grant of U.S. $\$ 631,819.00$, was submitted to U.S. State Department through SAWSO in February 1990 for the basic Medical and Administration programmes. This was kindly accepted and approved by the U.S. State Department. 


\section{TOTAL FUNDING}

AS AT 30TH APRIL 1991 (US $\$$

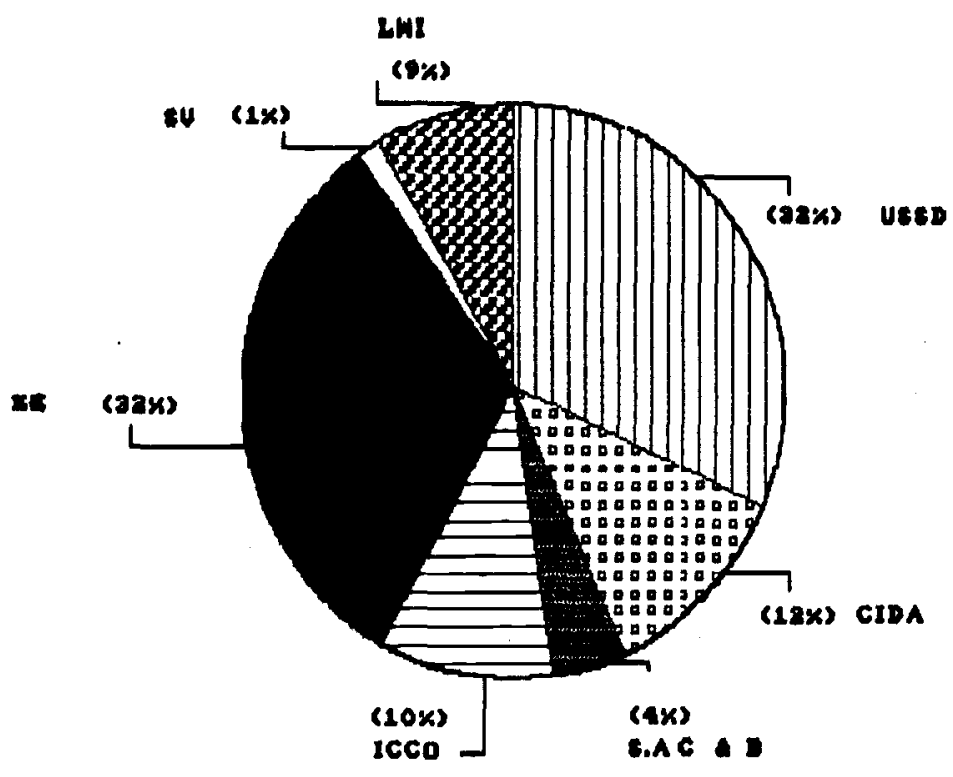

\section{MANAGEMENT STRUCTURE}

The Salvation Army, Afghan Refugee Assistance Project, through its main office based at Peshawar, is responsible for the overall activities in the field.

The Territorial Commander at The Salvation Army, Territorial Headquarters at Lahore. Colonel Farman Masih is the person officially responsible to International Headquarters for all work of The Salvation Army in Pakistan. 


\section{THE SALVATION ARMY \\ Afghan Refugee Assistance Project \\ PAKISTAN}

The Director of this project Captain Ivor S.Telfer is based at Peshawar Field Office, and is a Salvation Army officer, reporting to the Territorial Commander.

At field level, each component of the project i.e Ghazi Medical Programme, Haripur Medical Programme, Vocational Training and Income Generation programmes, are being supervised and implemented by Dr.Zainul Abedin, Dr.Abdul Wahab and Mr.Ghulam Jelani respectively. These programme officers were directly responsible to the Director. All these programme officers are assisted by their administrative staff.

The Project Accountant Mr.Abid Shehzad, Manager Administration Syed Mehmood Asghar and their ancillary staff are based in Peshawar office providing financial and administrative support to their colleagues in the field. They both report directly to the Director.

The field offices at Haripur and Ghazi are responsible for daily work and support to the staff working in the BHUs. These offices send monthly progress reports on their activities, to Peshawar office.

The Peshawar office, besides providing financial and administrative support to the field offices, is responsible for preparing monthly financial reports and periodical progress and narrative reports on the programmes as per donor requirements.

Further details on the management structure can be found in the Administration section. 


\author{
THE SALVATIOH ARMY \\ Afghan Refugee Assistance Project \\ PAKISTAN
}

\title{
BASIC MEDICAL PROGRAMME
}

\section{OPERATIONAL DETAILS}

\section{INTRODUCTION}

Health cover to the Afghan Refugees is being provided by the Government of Pakistan with UNHCR's assistance through the office of the Project Director Health (PDH) for Afghan Refugees. The PDH runs 108 BHUs in various districts and tribal agencies of the N.W.F.P. Another 86 BHUs and 10 hospitals in the N.W.F.P are being run by NGOs in some of the settled districts with the permission of the PDH. A total therefore of $194 \mathrm{BHUs}$ are in operation providing medical cover to an average of 11,500 refugees to each $\mathrm{BHU}$.

The Salvation Army's basic medical programme commenced with the inception of the project in August 1982 in Ghazi refugee camps.

In the beginning there were only two basic health units but later on the PDH requested four more BHUs be established at Haripur Refugee camps. BHU 1 and 2 at Haripur were established in April 1984. BHU 3 in April 1985 and BHU 4 was established in February 1986, thus bringing the total number of BHUs to six.

Through these Basic Health Units, the project was able to provide Comprehensive Health Care services to an estimated 80,000 refugees residing in both settlements.

At the commencement of the project, only curative health facilities were provided but it was soon realized that the number of patients visiting the BHUs instead of decreasing was considerably increasing. After realizing this fact, efforts were made to find out the reasons for the increase in the illnesses and it was found that most of the patients suffered from some of the common communicable and water borne diseases which could be easily prevented. It was found that women and children were the most affected.

It was soon realised that curative facilities would not be sufficient unless something was done to prevent these diseases from recurring. There was also a need to create awareness among the refugees especially the women and children about their recurring health problems. 


\section{THE SALVATIOH ARMY \\ Afghan Refugee Assistance Project \\ PAKISTAN}

This realisation forced the project management to change its strategy of curative health and after reviewing the whole programme, the management, after much work succeeded in evolving plans and strategies to cope with the challenge of communicable as well as some of the common diseases among the refugee community.

In order to implement these new plans and strategies in the medical programme, the project introduced a preventive health aspect in the BHUs and commenced with the recruitment of female medical staff. This recruitment was due to the fact that females were better accepted among the refugee population than the men, because of the cultural and traditional beliefs of the Afghans.

Three preventive health teams, each headed by a Female Medical Officer and female support staff were introduced and added to the already existing three curative health teams headed by Male Medical Officers and their male support staff, both at Haripur and Ghazi camps.

Initially these preventive teams were not fully aware of the standard preventive health measures and practices and in order to further enhance the knowledge of the staff on preventive measures, in - service training sessions were commenced with the help from The Salvation Army Pakistan. This assisted the staff in learning much and within a short period of time. most of the staff were quite aware of preventive health care practices.

In order to improve the knowledge of the community regarding preventive health practices, the project also undertook the task of training Community Health Supervisors (CHSs), this training programme was initiated in 1984.

At a later stage, a full component of Community Health Education programme was commenced in 1986 to train Community Health Supervisors and volunteer Community Health Workers, who in turn could assist their community with minor day to day health related problems.

Three Public Health teams, headed by a sanitarian and project trained Community Health Supervisors (CHSs) and Community Health Workers (CHWs) were also deployed in the six BHUs to work on alternate days and implement their programme of creating awareness among the people through health education. 


\section{THE SALVATION ARMY \\ Afghan Refugee Assistance Project \\ PAKISTAN}

The project then evolved a strategy to combine the activities of Curative, Preventive and Public Health teams to give birth to a comprehensivePrimary Health Care Programme.

The overall medical programme of The Salvation Army, Afghan Refugee Assistance Project revolves around the following four major objectives:

1. TO IMPROVE THE GENERAL HEALTH OF THE REFUGEE POPULATION.

2. TO CATER FOR MEDICAL EMERGENCIES.

3. TO DECAEASE THE INCIDENCE OF COMMUNICABLE DISEASES.

4. TO IMPROVE THE KNOWLEDGE OF THE COMMUNITY REGARDING PREVENTIVE HEALTH PRACTICES.

\section{HEALTH PROGRAMME DEVELOPMENT}

During the current reporting period some major changes have been brought about in our Medical Programme.

1. THE INTEGRATION OF PROGRAMMES

Previously, the Basic Medical and Community Health Education programmes were being implemented independently by the Medical Programme Officers and the Community Health Education Programme Officer. This created problems at the field level between these two programmes and it was discovered that the assistance expected by the medical programme from the health education staff was not sufficient.

The Project Management, after assessing the situation and considering all the facts, decided to integrate the medical and community health education programmes and bring both the programmes under the supervision of one programme officer. This has now been completed and the trained Community Health Supervisors and Community Health Workers have become an extension of the medical programme. They can now 
provide the correct assistance to the medical staff who in turn can provide day to day supervision and assistance to them.

The Project Management commissioned an Internal Medical Services Analysis in order to assess the Medical and Health Education programmes. Another reason for this was to bring about some changes in the programme and emphasise further the preventive aspect of the programme as opposed to the curative aspect so that the medical programme could more easily be transferred to Afghanistan at a repatriation. The idea was to create less problems for the refugees who by now are very much dependent on curative medicine.

A very thorough baseline study to be used for internal discussions was conducted by Mr and Mrs.Derek Jackson. The findings of the report were discussed in detail by the Project Management. The whole process of discussions, reviews, assessments and implementation took more than one year to complete.

The Project Management are happy to inform that all the agreed changes have now been introduced and implemented in the programme. An important point to note is that total ownership of these changes in the programme has been achieved at all staff levels due to the internal consultation during the whole process of this Internal Medical Services Analysis.

\section{STAFF TRAINING}

Apart from the continuous on - the - job training imparted by the senior management, specific training was undertaken. This was to train para - medical and other BHU staff like CHSs, CHWs and Sanitarians in other disciplines like Vaccination, Malaria Supervisor and Nursing Assistant so that they could use this extra training in their respective areas, after repatriation, in the absence of required para - medical staff.

In this connection a total of 39 refugee staff have been trained in giving vaccines, treatment and dressing of wounds, and treatment and control of malaria. 


\section{THE SALVATIOH ARMY \\ Afghan Refugee Assistance Project \\ PAKISTAN}

\section{REDUCING THE EMPHASIS ON MEDICINES}

The basic medicine list used by the programme was cut from 103 items to 77 . This together with active education and control of the doctors at the BHUs, has commenced the process of moving from predominantly curative to preventive.

More specifically, most of the medicines on the list have been replaced with generics and the prescription of medicines in the BHUs has been reduced to a maximum of 3 medicines per patient.

The purpose of these measures is to attempt to prepare the refugees for their eventual return to Afghanistan where health facilities are at very low levels. Further, this reduction in curative medicine is vital if a full Primary Health Care (PHC) programme is to be established. (Annex 12 is the revised medicines list.)

4. INCREASED EMPHASIS ON HEALTH EDUCATION

As part of the move towards PHC, increased emphasis is being given on health education to the refugees. For this reason a separate room has been constructed in each BHU to give health talks to all the refugee patients attending the BHU for the treatment of different diseases. All the patients have to go through this room and they do not receive any medication from the doctor unless they participate in a health talk session chaired by one of the BHU staff.

5. FAMILY RECORD - MEDICAL

The Project Management has decided that all the medical records of the refugees being kept in the BHUs, which include the Family Book, Ante Natal cards and Under Two Road to Health charts, should be given to the refugees prior to their departure to Afghanistan so that this could be used as reference by any health workers who are in the area.

Another step taken in this regard is the issuance of birth certificates to the new born babies in the camps. These certificates will also help the health workers, to evaluate the immunization status of the child. Further, by issuing these 
certificates, this has been an incentive to encourage registration of births and thereby improve immunization and under two clinic coverage of the children.

As the medical programme has been transferred to SCF(US), it will be their decision whether or not to implement this.

\section{PRIMARY HEALTH CARE SERVICES}

The project management in preparation for future repatriation, evolved a strategy to train as many men and women as possible in primary health care, so that these trained personnel could be of help and assistance to their relatives and community.

In doing so, Canadian International Development Agency (CIDA) has funded the training of a total of 14 Community Health Supervisors (CHS) and 432 volunteer Community Health Workers (CHW), both at Ghazi and Haripur camps.

Each CHW is responsible for 30 families and similarly one CHS is responsible for $30 \mathrm{CHWs}$. The role of these health workers is to provide simple treatment to sick people at the time of need, educate and create awareness among the refugee population about health prevention and to assist the BHU staff in locating different defaulters so as to accomplish their targets for immunizations, ante natal and post natal care, under two clinics and treatment of T.B patients.

Similarly, again funded by CIDA the project commenced the training of Female Health Supervisors (FHS) and Female Health Workers (FHW) both at Ghazi and Haripur camps. The training at both Ghazi and Haripur has been completed and a total of 8 FHSs and 248 FHWs are working in Ghazi camps and 36 FHSs and 431 FHWs in Haripur camps.

After the completion of training, the FHSs become part of the BHU staff and are paid staff members. Each FHS supervises a total of 12 FHWs who are volunteers, and each FHW is responsible for 12-15 families in respect of providing assistance at the time of need.

The target group cared for by these staff is the women and young children (under the age of 5) who constitute $44 \%$ of the total refugee population and are the most vulnerable group. Their health is always at 


\section{THE SALVATION ARMY \\ Afghan Refugee Assistance Project

risk because of multiple pregnancy, lack of knowledge about ante natal and post natal care, nutrition, personal hygiene and prevention of some of the common diseases.

Keeping in mind the above facts, now the project is placing more emphasis on the prevention of diseases rather than curing them.

A variety of services being provided in this respect are as follows:

1. ANTE NATAL CLINIC

According to the WHO / UNICEF / UNESCO book "Facts for Life", every year half a million women worldwide die from problems linked to pregnancy and childbirth, leaving behind over one million motherless children.

The Maternal Mortality Rate (MMR) and the Infant Mortality Rate (IMR) in Afghanistan is among the highest in the world. It is assumed, although no baseline survey was ever completed, that this still holds true for the refugee camps in Pakistan.

The above clinics were commenced with the aim of DECREASING THE MATERNAL MORTALITY AND INFANT MORTALITY RATE in the camps where the Army is working. These clinics are conducted by Lady Health Visitors (LHVs), once a week in each BHU for the pregnant women who are usually in their second trimester.

The women coming for the first time are registered in the $\mathrm{BHU}$ and an ante-natal card is completed stating all the relevant information. During the reporting period, 2213 new cases were registered in the Ante Natal clinics for future care, this was $89 \%$ of total pregnant women in the camps. Similarly, $98 \%$ of the total registered women in these clinics were attending on a regular basis.

Tetanus Toxoid (TT) injections are given to the women who have not previously been immunized against tetanus or had incomplete immunization status. A total of 8623 women received their TT injections through these clinics. 


\section{THE SALVATIOH ARMY \\ Afghan Refugee Assistance Project \\ PAKISTAN}

The women attending the ante natal clinics receive education about ante natal care, importance of immunizations during pregnancy, nutrition and post natal care including care of the newborn baby and breast feeding etc.

The expectant mothers are also encouraged to contact the BHU staff, Traditional Birth Attendants (TBAs), the Female Health Supervisor's (FHSs) or the Female Health Worker's (FHWs) so that they can assist them with the safe delivery of their babies.

To further encourage these women to contact the BHU staff at the time of delivery, the project has introduced birth certificates in the BHUs and all the women, whether registered or unregistered at the BHU, receive a birth certificate for the new born baby signed by the BHU medical officer.

This way all the new born babies are registered for immunizations and the under two clinic, for future care and assistance. These birth certificates can play an important role after refugees repatriation as it will give accurate age of the child.

During the current reporting period out of a total of 2065 recorded births 1477 or $71 \%$ of the deliveries were assisted by the above mentioned staff.

2. UNDER TWO CLINIC

It is evident from the name that this clinic is held for the children who are under the age of two. The upper age limit is due to the fact that children under two are more susceptible to diseases than the older children.

The objective of the under two clinic is TO HELP EVERY CHILD ACHIEVE ITS MAXIMUM POTENTIAL OF MENTAL AND PHYSICAL DEVELOPNENT and the main aim of this clinic is to provide low cost curative and preventive care to meet the pediatric challenges, focusing on the following four essential components of treatment: immunization, growth monitoring, health education and curative care. 


\section{THE SALVATION ARMY \\ Afghan Refugee Assistance Project \\ PAKISTAN}

This clinic is held once a week in each BHU and all the children under the age of two are encouraged to attend. The children are weighed and registered in the clinic and a growth monitoring (Road to Health) chart is completed for every child mentioning all the relevant information. Special attention is given to those children who are malnourished or undernourished due to varying reasons.

At the end of the current reporting period a total of 2478 new cases were registered in the Under Two clinic and the average visits per child to the clinic was 2.22 times per month.

Out of a total of 2814 children registered at the under two clinic. at the end of the project period, 506 were underweight and of these 324 were 1st degree malnourished, 132 were 2nd degree malnourished and 50 were 3rd degree malnourished. 78 children showed an improvement in their weight.

The immunization status of every child is checked and if found incomplete, they are referred to the vaccinators for immunizations. All the immunizations are also recorded in the growth monitoring chart and the mothers are also educated about the importance of immunizations.

During the current reporting period, a total of 13052 attendances of under two children were recorded by the vaccinators.

The mothers are advised regarding weaning food and preparation of different food items. In most of the cases the LHVs practically demonstrate and prepare different food items in the presence of mothers and the prepared food is given to all attending children to eat. By doing this, the mothers are encouraged to feed their children the same way in their homes.

The mothers are also educated about breast feeding and its importance because bottle feeding, especially in the poor communities, is a serious threat to the lives and health of the children.

The mothers are also informed about the control of diarrhoea through O.R.S. and its preparation at home. Diarrhoea causes dehydration, which kills approximately 3.5 million children worldwide every year. Diarrhoea is also a major cause of child 
malnutrition. The main causes of diarrhoea are poor hygiene and lack of clean drinking water.

3. EXPANDED PROGRAM OF IMMUNIZATION (E.P.I)

This is one of the most important aspects of the preventive health services and is receiving much importance because of its value and effect on future generations. Immunization protects against the six major diseases of Polio, Tuberculosis, Measles, Whooping cough, Tetanus and Diphtheria. A child who is not immunized is more likely to become under - nourished,disabled and to die.

Facts for Life shows that worldwide, without immunization, an average of three out of every hundred children born will die from measles, another two will die from whooping cough, one more will die from tetanus, and out of every two hundred children born, one will be disabled for life by polio.

In order to attempt to fully immunize the refugee population, one vaccinator is stationed at each $\mathrm{BHU}$ where he works for three days in co - ordination with female staff of the BHUs and for the other three days he goes into the camps for out - reach activities. He travels to every part of the camp and locates and immunizes the defaulters as well as registering and immunizing new cases, with the help of CHSs and CHWs.

Out of a total of 5600 under two population, 13052 different immunizations were given to the children. 2605 under two children were able to be fully immunized during this reporting period, i.e $46 \%$ of the estimated under two camp population. During the previous reporting period 2716 under two children were fully immunized therefore an approximate percentage of fully immunized under two children is $95 \%$.

Similarly, out of a total of 17600 women in Child Bearing Age, 8623 attendances were recorded by the vaccinators and 2680 CBA women or $15 \%$ of the estimated CBA population were fully immunized during the reporting period. It is not possible from our records to calculate the percentage of the estimated CBA women who are now fully immunized against Tetanus. 


\section{THE SALVATION ARMY \\ Afghan Refugee Assistance Project \\ PAKISTAN}

The defaulters were also located and motivated by the staff of the outreach team, who are provided with all the particulars of the defaulters by the vaccinators, who keep a complete record of the immunizations status of the children.

Now with the new change brought about in the E.P.I programme by the W.H.O. and the Project Director Health for Afghan Refugees, children under the age of two have been made the primary target for immunizations. Similarly, all the women in Child Bearing Age (CBA) have been made the primary target for Tetanus Toxoid injections.

One of the most important aspects in connection with preparing the refugees for repatriation is to completely immunize the whole population. The Salvation Army has undertaken this responsibility and is striving hard to immunize as many under two children and CBA women as possible.

\section{HEALTH EDUCATION}

Health education is yet another factor which plays a very important role in improving the health of the community. More than half of all illnesses and deaths among the young children is caused by germs which get into the child's mouth via food and water mainly because of lack of knowledge about personal hygiene.

In poor communities without latrines, without safe drinking water and without safe refuse disposal, it is very difficult for families to prevent the spread of germs. It is therefore vital for the people to be aware of different prevalent health problems and their prevention.

In order to further reinforce the message of health education and to create awareness among the people in the camps, the project management decided to built a separate room in each BHU, particularly for the purpose of imparting health education, known as the "Health Education Room". Health education is given by the BHU staff to most of the patients attending the BHUs, in small groups of 10 people. During the concluded period a total of 147,625 patients attending the $\mathrm{BHU}$ received health education 


\section{THE SALVATION ARMY \\ Afghan Refugee Assistance Project \\ PAKISTAN}

on a number of health related issues and topics. This was $87 \%$ of the total attendances at the BHUs.

This health education has been made compulsory and no patient is examined by the doctor unless he has been to the Health Education Room and received some teaching.

Health Education is also being given in the camps to both men and women by respective outreach workers.

A total of 67710 male attendances and 35016 female attendances received health education on a variety of topics which cover personal and environmental hygiene, prevention of communicable diseases, importance of immunizations, clean drinking water, control of diarrhoeal diseases, prevention of Malaria and T.B, importance of O.R.S and its preparation etc.

Similarly the outreach workers visit the boys and girls schools in the camps and impart health education on personal hygiene, prevention from communicable diseases, importance of immunization, prevention from diarrhoea and use of clean water and food. During the reporting period the outreach health workers had attendances of 55513 boys and girls for health education delivered in 1136 sessions.

5. HOME VISITS

The female health workers and the female BHU staff contact the female refugee population through regular home visits. Apart from imparting health education they also follow up un registered and registered ante natal, post natal and malnourished under two children.

A total of 3802 ante natal and 3581 post natal cases were contacted in order to ensure the correct ante and post natal care of the women, care of the new born baby, breast feeding and weaning food practices.

6. GENERAL OUT PATIENT DEPARTMENT CLINICS

Both preventive and curative health are part of any Primary Health Care programme especially among the refugee 
community with whom we work. This community has some very urgent curative health needs like Malaria, T.B, Skin Infections, Gastric Problems and Respiratory Tract Infections etc, which we can not ignore and that is why some sort of balance has to be kept between the preventive and curative aspects of the programme in order to care for the refugees both physically and mentally. This is also very essential for the success of any health programme.

The project through its general Out Patient Department (OPD) clinics for males and females, six days a week, is responding to the urgent medical needs of the people. Each OPD is conducted by a male and female medical officer in each BHU on alternate days. The patients are examined by the medical officer and prescriptions / tests are advised accordingly.

During the reporting period a total of 170,653 attendances were recorded at the general OPD and received treatment for their illnesses. The visits comprised $18 \%$ men, $36 \%$ women, $23 \%$ children under 5 years of age and $23 \%$ children between the age of 5 and 14 years.

About $81 \%$ of the total patients were treated against six common diseases i.e. Respiratory Tract Infections (28\%), Gastric Problems (18\%), Skin Infections (9\%), Fever of Unknown Origin (PUO) (8\%). Psychosomatic Illnesses (8\%), Obstetric problems $(6 \%)$ and others $(4 \%)$.

To support the medical officers in their diagnosis and treatment, field laboratories are also in operation at Ghazi and Haripur camps where various specimens are examined by the skilled Laboratory Technicians, at the request of the respective medical officers.

A total of 25851 specimens were examined by these field laboratories at the request of the BHU medical officers and of these, 3157 or $12 \%$ specimens were found to be positive or abnormal. Out of the total specimens examined, $84 \%$ were blood samples, $10 \%$ were sputum samples, $3 \%$ were urine samples, $2 \%$ were stool samples and $0.7 \%$ were for pregnancy tests. 


\section{THE SALVATION ARMY \\ Afghan Refugee Assistance Project \\ PAKISTAN}

7. TUBERCULOSIS (T.B) CONTROL PROGRAMME

This is a very important programme being implemented in the camps for the refugees. T.B is a very common disease among the refugee population and it has taken much effort on the part of the health personnel to prevent its spread among the refugee population.

There are still many T.B patients in the camps, but the situation is not as alarming as it was in the earlier days of the refugee programme.

Due to the prevalence of this disease, special T.B clinics are held in every BHU on a fortnightly basis. During these clinics the registered T.B patients are examined by the medical officer and treatment is given to them. Similarly the suspected T.B patients are referred for $X$-rays and sputum examinations and if found positive or suggestive, they are given anti T.B treatment.

During the reporting period $96 \%$ of the 97 registered T.B patients were receiving their anti-tuberculous treatment on a regular basis.

A total of 66 T.B patients completed their full course of treatment and 116 new T.B patients were registered in the T.B clinics and commenced anti T.B treatment after investigations.

Close family members of the positive T.B patients were also screened regularly to find out whether they have been afflicted by the disease or not.

Efforts are also made to ensure that all the registered T.B patients come and receive their respective medicines on a regular basis. If in some cases the patients are not regular and default in their treatment and do not come to the BHU on the specified dates, they are located with the help of CHSs and CHWs who, after motivation, bring them to the BHUs to continue the treatment.

The patients are also educated about the preventive measures necessary to check the spread of this disease among the family and the community. 


\section{THE SALVATION ARMY \\ Afghan Refugee Assistance Project \\ PAKISTAN}

In some cases, specialised consultation is also provided by the ICD (Italian Co-operation for Development, an Italian agency implementing the T.B control program for Afghan Refugees). ICD is also providing technical and material support, in the shape of Mobile X-ray units, training of laboratory personnel, supply of anti T.B. medicines and laboratory reagents for sputum examination etc. Our sincere thanks go to ICD and their present Programme Coordinator for this assistance.

\section{MALARIA CONTROL PROGRAMME}

Malaria, one of the most dreadful of all tropical diseases, is spreading at an alarming rate, with roughly 100 million cases reported annually in Africa alone, according to latest reports by the World Health Organisation (WHO).

Worldwide a total of between two and five million people die of malaria every year, besides causing malnutrition and other complications in children and adult patients, and western press sources comment that scientists have yet to come up with a completely reliable medicine for the disease.

Over $40 \%$ of the worlds population lives in regions where the risk of contracting malaria is very high. Malaria is one of the most common diseases among the refugee population. To control this disease, a Malaria Supervisor has been attached to each BHU, whose responsibility it is to take blood samples from the suspected cases and provide them with a complete treatment regime, if found positive after the laboratory examination. The suspected cases are also provided with radical treatment.

The malaria supervisors collected a total of 20666 slides for the investigation of malaria and of these 2141 or $10 \%$ were found positive. All these malaria positive cases were able to receive full anti malarial treatment.

The malaria supervisors also collect blood samples for mass screening of the population especially when any case of Plasmodium Falciparum malaria is detected. As a routine the Malaria Supervisor collects blood samples from twenty families residing in the area where the Falciparum case is detected. 


\section{THE SALVATION ARMY \\ Afghan Refugee Assistance Project \\ PAKISTAN}

The reason for this is that this type of malaria is very dangerous and if not detected and treated in time, may cause death. During this period a total of 327 patients have been detected who were suffering from Plasmodium Falciparum (PF) Malaria. This is of serious concern as in 1988 the PF positive number were 211 and 157 in 1989.

The following chart shows the incidence of Plasmodium Falciparum and Plasmodium Vivax Malaria in 1988, 1989 and 1990.

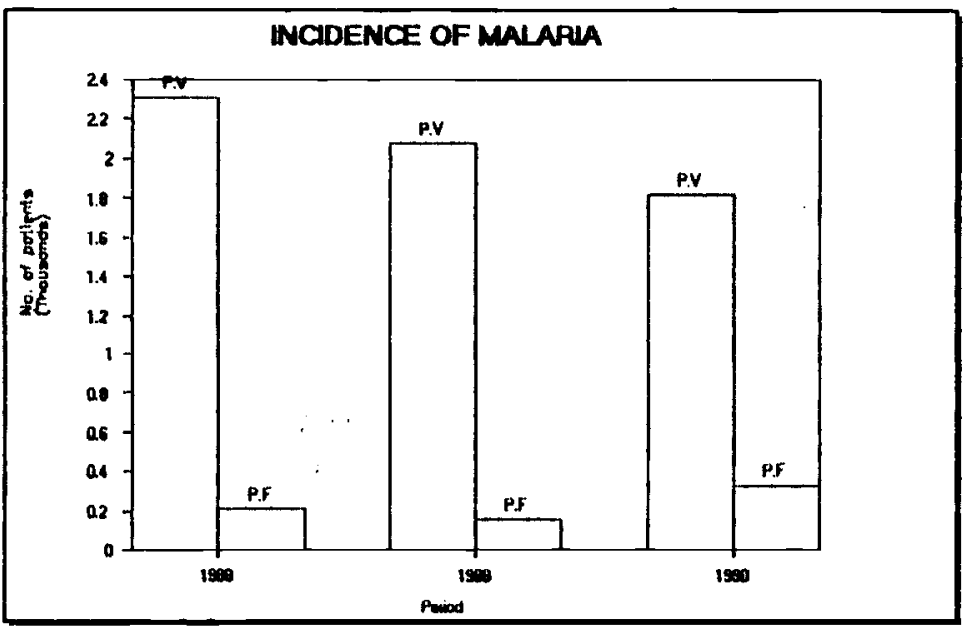

To control the spread of disease and especially the breeding of mosquitoes, the office of the Deputy Project Director Health (GOPIUNHCR) for Malaria Control supplies malaria insecticide for spraying, in the camps, once a year. Malaria supervisors with the help of male outreach health workers carry out thls malaria spray campaign in the camps.

It is of much concern to the Project Management that during the current period, no such spray campaign has been undertaken as no insecticide was given to the project by the GOP/UNHCR. The reason for this non supply is that some resistance to Malathion, the insectical drug, has been reported. It is important to note that the project has noticed, and reported to the GOP/UNHCR, that malaria and particularly PF is increasing. This seems to be mainly due to the lack of the Malathion spray campaign during 1990.

The camp people are also educated by the Sanitarians, Malaria Supervisors, CHSs and CHWs to keep their surroundings clean and fill in the ditches and other water ponds in the camps which 
contain stagnant water, so as to decrease the breeding grounds for mosquitoes.

During the concluded period, the outreach workers managed to close 168 water ditches in different parts of the camp.

\section{MINOR SURGERY}

In order to deal with minor injuries, wounds and burns etc., three nursing assistants have been attached to the curative team. These nursing assistants work alternate day in each BHU on male days, and on female days one of the female staff from the $\mathrm{BHU}$ attends the patients.

Their patients are usually referred by the outreach workers i.e. CHSs and CHWs. Nursing assistants dress the wounds, burns and skin infections under the guidance of the medical officer. The injections to T.B and other general patients and intravenous therapy to emergency patients is also given by the Nursing Assistants under the supervision of medical officer.

During the current reporting period the nursing assistants gave 13615 injections, dressed 17172 wounds, dressed and treated 921 burn cases, drained 500 abscesses through incisions, stitched a total of 80 wounds, conducted 60 circumcisions and the lavage of 13 persons ears.

10. REFERRAL OF PATIENTS / EMERGENCY MEDICAL COVER The medical officers conducting the general OPDs also refer patients who may need hospitalization or any specialized treatment and or investigation, to different Government hospitals at Peshawar and Abbottabad. Similarly, emergencies are also referred to these hospitals and in most of the cases transportation facilities are also provided by the project.

The medical officers referred a total of 1183 patients to government hospitals for investigation and or specialized treatment from Ghazi and Haripur camps. 
To deal with other medical emergencies, which do not need hospitalisation, medical and para medical staff remain on emergency duty after the duty timings in Ghazi camps only.

The reason for this being that in Ghazi there is no other facility available to the refugees outside their camp and also the field office at Ghazi is very close to the refugee camps as compared with Haripur, where the field office is about 15 k.ms away from the nearest camp. The refugees in Haripur usually take their emergencies to the government civil hospital or to the private hospitals in Haripur town.

During the current reporting period emergency medical cover was provided to a total of 2357 patients. Most of these cases were problems in pregnancies, burns, road accidents and general severe pain etc.

\section{CAMP SANITATION}

The members of the male outreach health workers team i.e. the Sanitarian and Community Health Supervisors are also responsible for the environmental or camp sanitation.

Their main role is to create awareness among the people about sanitation and also to assist them in the construction of proper pit and surface latrines and places for the safe disposal of the waste in the camps. This team also educate the people about the proper maintenance and use of these latrines.

During the concluded period, while checking on the camp sanitation, a total of 5786 pit and surface latrines have been inspected every month by the outreach workers.

Another important task of the same team is to advise the people living in the camps about the proper use of water from the lake. river and wells.

The use of contaminated water by the refugees has created many health problems, especially the gastro -intestinal diseases. This sanitation team advises refugees to use clean water for drinking and cooking purposes. The same team is also 


\section{THE SALVATION ARMY \\ Afghan Refugee Assistance Project \\ PAKISTAN}

responsible for the inspection and upkeep of water sources in the camps.

These outreach workers inspected a total of 166 water tanks, 69 water taps and 474 wells in the camps once a month and advised people about proper drainage of water. This team also managed to chlorinate all the wells once every three months.

Yet another role of this team is to visit the shops in the camps selling edible food and give advice to the shopkeepers to protect their merchandise from flies and dust and always sell fresh and clean food items. In this regard a total of 1930 visits have been made to general food and butchers shops during the reporting period.

Rabid dogs in the camps are a threat to the lives of the people and in some cases people have died from rabies. The health workers always instruct the people to kill the rabid dogs and keep their pet dogs inside their houses. During the same period the health workers with the help of refugees killed four rabid dogs.

12. MOTIVATION OF DEFAULTERS

The male outreach workers team also assist the BHU staff in implementing and carrying out some of their programmes by locating and motivating defaulters who are registered in different clinics (e.g. T.B, Malaria, Ante - Natal, Under two and E.P.I) but who fail to come on a regular basis as required by the schedule of that clinic. This makes their treatment irregular and therefore less effective.

All these defaulters are located on the instructions of the BHU medical officer and concerned BHU staff and are encouraged to complete their full course of treatment or immunization. This helps to ensure that the patient is fully cured and does not cause problems for other people. All these defaulters are followed up on a regular basis.

During the current period 34 T.B. defaulters, 794 Under Two clinic defaulters, 688 Malaria cases and 12598 under two children for vaccination have been located, motivated and or referred to the BHUs. 


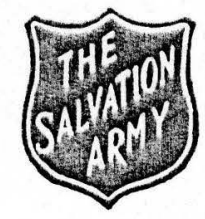

\section{THE SALVATION ARHYY \\ Afghan Refugee Assistance Project \\ PAKISTAN}

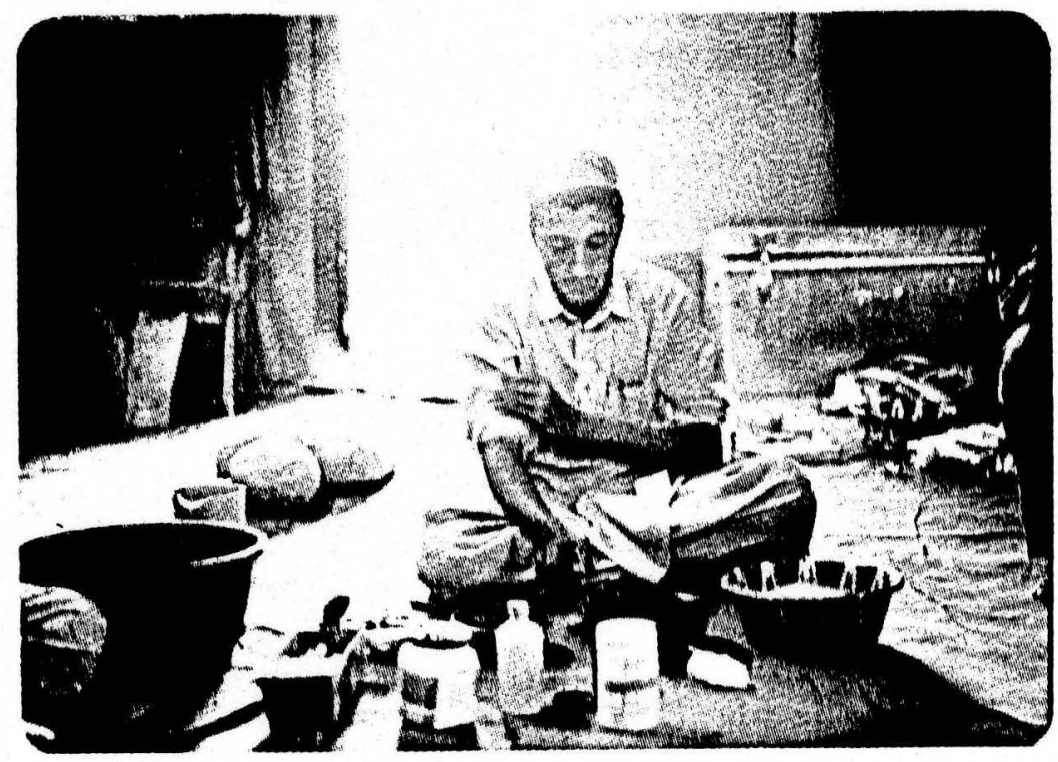

Community Health Worker bein tested.

Waiting for medical treatment at the Basic Health Unit.
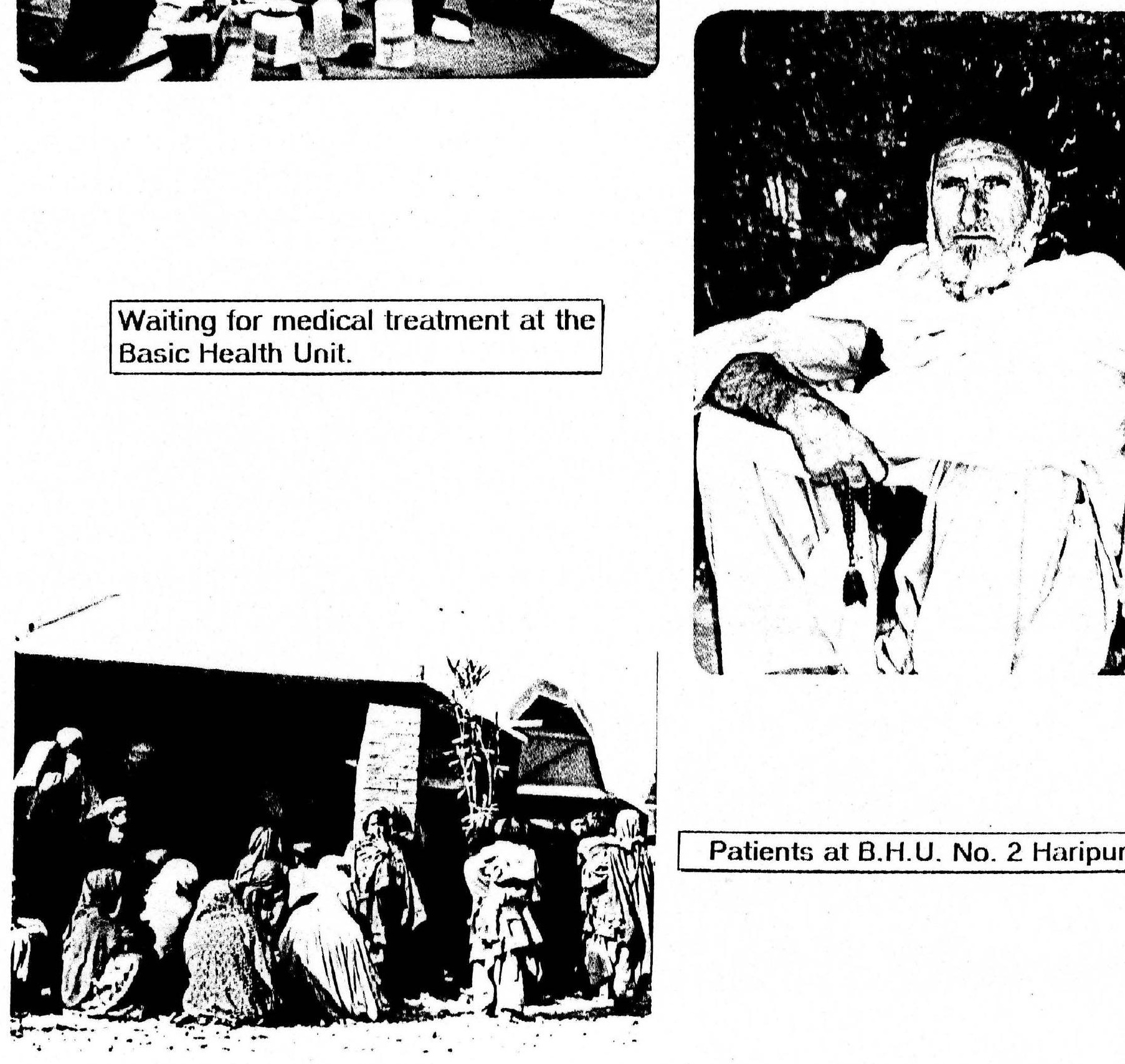

Patients at B.H.U. No. 2 Haripur 


\section{THE SALVATION ARMY \\ Afghan Refugee Assistance Project \\ PAKISTAN}

\section{ASSISTANCE}

These outreach workers teams are of great help and assistance to BHU Staff in implementing their programmes. They provide assistance and support to their BHU colleagues who, from time to time, undertake some special task or programmes like mass immunization programmes for women and children, malaria spray campaign in the camps, carrying out different surveys, chlorination of water wells and location of disabled people in the camps etc. They also assist in spreading different messages from the BHUs among the camp people.

\section{BIRTH AND DEATH RECORDS}

Another important task being undertaken by these teams is the collection of monthly figures on births and deaths in the camps and if possible, the causes of deaths are also recorded. This record help the medical teams to cross-check the births and deaths with their own records and also helps them in issuing a birth certificate for the new born child and registering him/her for future care.

N.B. Readers are advised that all the medical statistics and the figures given in the above report have been taken from the consolidated statistics for Ghazi and Haripur camps. For interested persons these statistics are attached at the end of this report. 


\author{
THE SALVATION ARMY \\ Afghan Refugee Assistance Project \\ PAKISTAN
}

\title{
ADMINISTRATION AND FINANCE
}

\section{ADMINISTRATION}

As mentioned earlier, Peshawar office is responsible for the overall administration of the project. It provided administrative and logistics support to the field offices which includes formulation of policies, supply of stationery, medicines and all other programme related materials necessary for the work in BHUs.

The Peshawar office also acts as a liaison between the field offices at Ghazi and Haripur and UN. Government of Pakistan. Afghan Refugee Commissionerate. Project Director Health and other voluntary agencies and donors, keeping them informed of all the developments in the Afghan Refugee medical programme.

All the progress and financial reports on the programmes are prepared and sent to the respective donors on a regular basis.

Monthly Project Management Meetings between the Director, the Programme Officers, Manager Administration and the Project Accountant were held in Peshawar and a number of matters pertaining to the development of the project were discussed. Additional planning meetings were also held between the Director and the concerned officer to discuss some specific matters.

Once every three months the Territorial Commander chaired a Quarterly Board Meeting in Peshawar comprising Financial Secretary, Project Director and the Project Management. Here he was updated on the activities of the previous quarter by all project management and plans were made and discussed for the following three moniths. The same Board took major policy decisions regarding the future of the programme.

ROLE OF THE ADMINISTRATION IN THE TRANSFER OF THE MEDICAL PROGRAMME TO SCF(US)

As referred to in the Executive Summary, the medical programme here reported was transferred to SCF(US) as at close of work on 30th April 1991. 


\section{THE SALVATION ARMY \\ Afghan Refugee Assistance Project \\ PAKISTAN}

This process commenced in the autumn of 1990 when Capt. Telfer initiated a dialogue with certain NGOs in Peshawar. With the kind assistance of U.S.State Department's representatives at Islamabad, he was able to find Save The Children Federation of the U.S, who in turn showed keen interest in taking over the whole medical programme.

The Director and the Programme Manager of SCF(U.S) visited the medical programme at Haripur on 6th December 1990 and on 8th January, intimated in writing to The Salvation Army their willingness to take over the programme.

After their intimation, the Project Management, especially Capt. Ivor S.Telfer the Director, Mr.Abid Shehzad the Project Accountant and Mr.Syed Mehmood Asghar the Manager Administration, commenced the groundwork for the transfer of the programme.

The following steps then happened:

A qualified finance person prepared the assets register.

All the inventories at the main office and field offices at Haripur and Ghazi and the BHUs at Haripur and Ghazi were updated.

A list of all the assets for transfer was prepared and

A list of all the staff members to be transferred was also prepared, indicating the number of years they have served with The Salvation Army, their present grade and the salary amount.

A meeting between the Director of SCF(US), Capt.lvor S.Telfer and Mr.Syed Mehmood Asghar was held on 21st February 1991. Some issues about the transfer were discussed and it was also decided that Mr.Mehmood would prepare a proposal and Capt. Telfer will prepare a budget for SCF(US) to submit to the U.S State Department, for the funding of the medical programme for the next year. This assistance was given at the request of SCF(US) and although the finally accepted narrative and budget are not those initially prepared, this technical assistance facilitated the final proposal formation.

Both the budget and the proposal were prepared and submitted to SCF(US) in the first week of March 1991 but there was some delay in SCF(US) submitting this to the U.S State Department. This caused the 


\section{THE SALVATIOH ARMY \\ Afghan Refugee Assistance Project \\ PAKISTAN}

Project Management some concern regarding its staff because it was felt necessary to inform the staff of all the changes at least one month before the termination of the grant period.

All the staff were issued termination letters on 24th of March but the Project Management could give no clear commitment that the staff would remain on the programme as no word was forthcoming from SCF(US).

The funding for the next period was confirmed by the U.S State Department in the last week of April 1991. SCF(US) were contacted and were requested to visit the Haripur and Ghazi Programme before 30th April and meet the staff and tell them about the transfer and also to physically take possession of the programme.

A meeting was arranged on 28th April at Haripur to which all the project staff were invited and they were informed of the decision taken by The Salvation Army regarding the transfer of the programme to SCF(US).

On 29th and 30th April 1991 all the assets and inventories were physically checked by the representatives of SCF(US) in Haripur and Ghazi and were transferred accordingly.

A total of 147 staff members with a total of 492 years of service. together with major assets worth Rs.1,899,612.00 (Purchase Value) have also been transferred, not to mention about all the assets in the field offices, hostels and BHUs. (Attached in Annex 11 is the list of major assets transferred to SCF(US.)

The Management was able to transfer all the staff related to the medical programme to SCF(US) except four staff members at Peshawar main office, including one Administrative Assistant, two guards and one gardener. The gardener and one guard were retired due to their age but the administrative assistant and the guard were left without any job. The Project Management is trying its best to place them in a reasonable job with some other agency.

All necessary assistance and help to SCF(US) is being provided by The Salvation Army on request by SCF(US). Recently the Project Management prepared new pay scales for the medical programme staff at the request of SCF(US) which, to some extent, have been implemented at the field level. 


\section{THE SALVATION ARMY \\ Afghan Refugee Assistance Project \\ PAKISTAN}

The fact that so many staff and assets have been transferred and the programme did not close for a single day is a major achievement. This has mainly been due to the detailed preparation by the Project Management prior to the transfer, the excellent assistance from U.S.State Department in Islamabad and the ability of the senior staff who have been transferred to SCF(US), especially Dr.Zainul Abedin and Dr.Nasreen Abbasi. Thanks go to SCF(US) for their part in the process.

\section{TRAINING}

The Project Management and mid level management, including the medical officers were exposed to a number of management courses at Pakistan Institute of Management in order to make them more conversant with modern management techniques. These courses make them better equipped for their own future and also assist them in running the programme in a better way.

\section{CHANGES TO THE ADMINISTRATION}

Some administrative changes which have been brought during the previous project continued during the reporting period. The first step taken previously in this regard was the elevation of Administrative Assistants to Assistant to Programme Officers giving them some more responsibilities. The next step taken was making the BHU medical officers more independent in their day to day work and making them fully responsible for all the BHU activities. Now the medical officers have been given more authority which they never enjoyed before.

New pay scales for the project staff were prepared by the management and were implemented at the beginning of the concluded funding period.

Another achievement by the administration was to computerise all the personnel records of the project staff, which helped in the preparation of a budget for SCF(US) and was also of great use while discussing the staff transfer. 
THE SALVATION ARMY

ORGANISATION OF AFGHAN REECGEE ASSISTANCE PRONECT (1988)

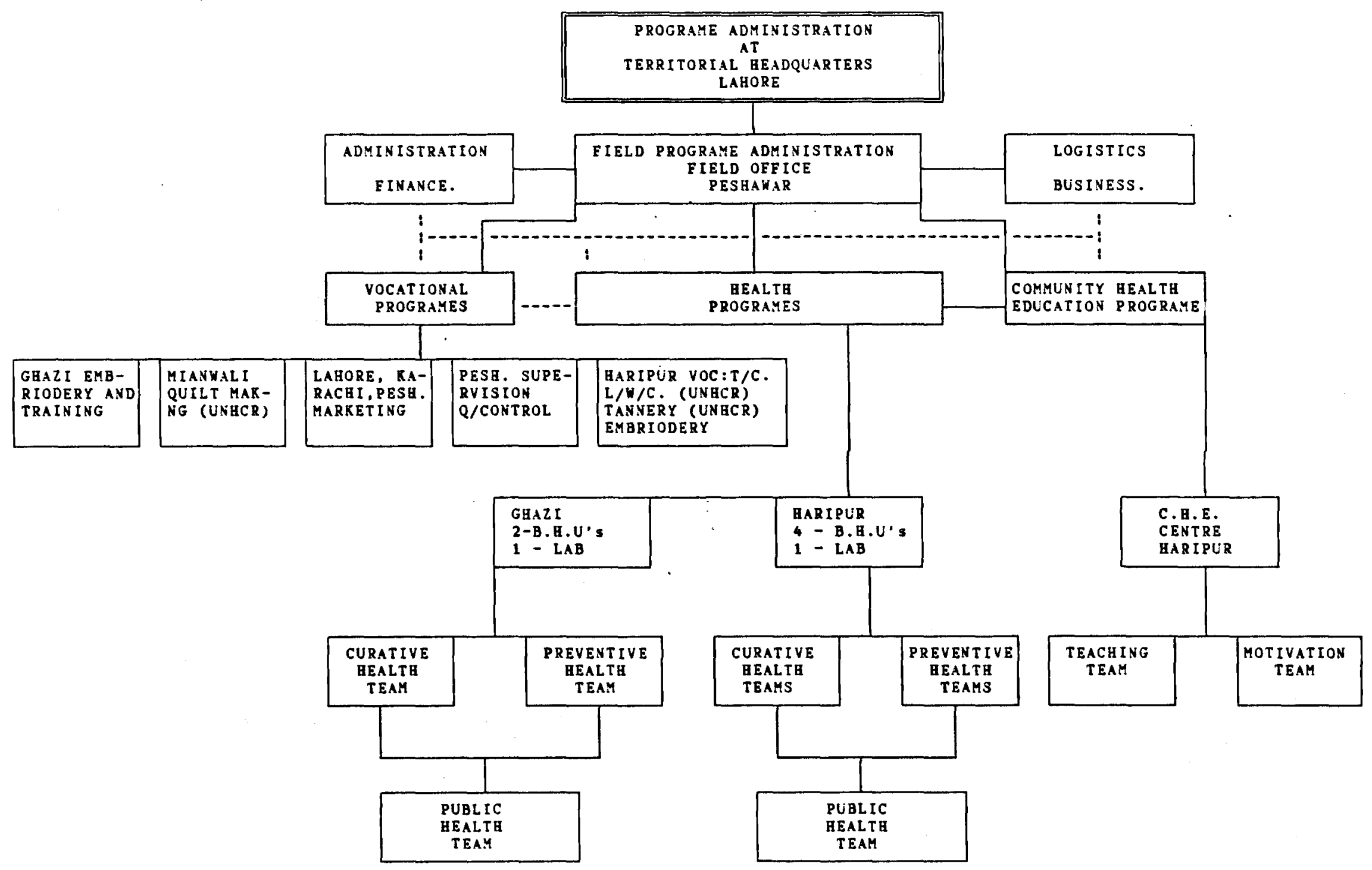




\section{THE SALVATION ARMY \\ Afghan Refugee Assistance Project \\ PAKISTAN}

The administration took another step for the welfare of the project staff and decided to insure all the staff against accidental death or injury. A decision in this regard was taken at the Quarterly Board meeting and instead of giving the uniform allowance, it was agreed to insure the staff against accidents.

The Manager Administration in consultation with the Project Director and concerned programme officers, introduced a new policy regarding the retirement of staff members.

The Director in consultation with Project Management also introduced separate work agreements for the Project Management, which were agreed to and accepted by the Territorial Commander.

\section{MANAGEMENT STRUCTURE}

Opposite is the original organogram for the project in place in 1988 on the arrival of the present Director. Overleaf is the organogram in place as at 30th April 1991.

During the development of any organisation, it is vital that the organisation has clear lines of communication, work flows and decision making. In an attempt to assist the field implementation of the programmes, much discussion under the direction of Capt. Telfer focused on the organogram.

As can be seen, lines of responsibility are clear, job titles are more specific and the new organogram reflects the integration of the health education component into the medical services.

Not only was this new organogram on paper but it actually was implemented, thereby providing better use of the resources of staff and money in supporting and guiding the field implementation.

One important factor was continually emphasised by the Director - the administrative and financial functions are there to support programme implementation, not to direct it, however, programme has an equal and opposite responsibility to the administrative and financial functions.

This system was found to be extremely efficient and effective and now some organisations are coming in an ad hoc manner to receive some suggestions about management structures, organograms and policies. 


\section{THE SALVATIOM ARMY \\ Afghan Refugee Assistance Project \\ PAKISTAN}

\section{- FINANCE}

At the commencement of this section, it is necessary for us to record our sincere appreciations to the U.S State Department Bureau for Refugee Programs for their continued funding of this project since 1982. Without their assistance, none of this project would have existed.

As mentioned in the First Interim Report, the Project Expenditure Board which was constituted to streamline all the expenses on the project, continued to meet regularly in Peshawar every Wednesday with the Director as the Chairman and the Project Accountant and the Manager Administration as its members.

This helped the Project Accountant in the control and planning of the income and expenditure on the project and the Programme Officers in ensuring that funds were utilised according to the individual budget line items.

Monthly financial analysis reports were also produced for all the projects by the finance department. This assisted the Project Management in monitoring their expenses on a monthly basis.

As this was the last year of The Salvation Army's involvement in the medical programme after successfully running it for nine years, during the last few months the finance department has been very busy with the task of preparing for the transfer of the medical programme to SCF(US) as at 30th April 1991.

In preparation for the transfer, the finance department was able to prepare a Fixed Asset Register from 1982 to April 1991. With the help of this register the Management was able to transfer all the relevant programme assets purchased from U.S State Department funding to SCF(US) at the end of the grant period.

The finance department was also able to produce income and expenditure accounts and a balance sheet for PD 734 (III) for the concluded grant period, which shows a nil balance. (See Annex 13 for Income and Expenditure Account and Balance Sheet)

Also attached in Annex 14 is the Expenditure Analysis sheet for the month of April 1991 which shows the total expenditure per budget line item relating to the approved budget line balances. 


\section{THE SALVATIOH ARMY \\ Afghan Refugee Assistance Project \\ PAKISTAN}

40

The reasons for the overspend in certain line items are as follows:

\section{a. SALARIES}

Due to the Gulf War, the increase in the prices of oil forced the rise in the prices of essential commodities. In order to give some relief to the people the Government of Pakistan announced an increase of Rs.200.00 per month in the salaries of its staff. Organisations were encouraged to follow suit.

The Project Management decided to give the same to the project staff and an amount of Rs.202,400.00 extra was spent in the salaries category. This amount was given as a one time payment in April, backdated to the date of the GOP increase, October 1990.

Another reason for the overspend in this category is due to the fact that this was the last grant, it was decided by the project management to award the staff on the medical programme for their hard work on the project for the last nine years in the form of a termination benefit to each staff member. An amount totaling Rs 577,565.00 was given to the Medical Programme staff.

\section{b. MAINTENANCE / PURCHASES}

The overspend in this category was due to the fact that the Project Management wanted to transfer all the vehicles to SCF(US) in perfect working condition. In doing so new tryes were put on all the vehicles, some of the vehicles whose insurances were nearing expiry dates were renewed, engines of three vehicles were completely overhauled and a second -hand engine was put in another vehicle.

Other overspends were slight so no mention is here made of them. 


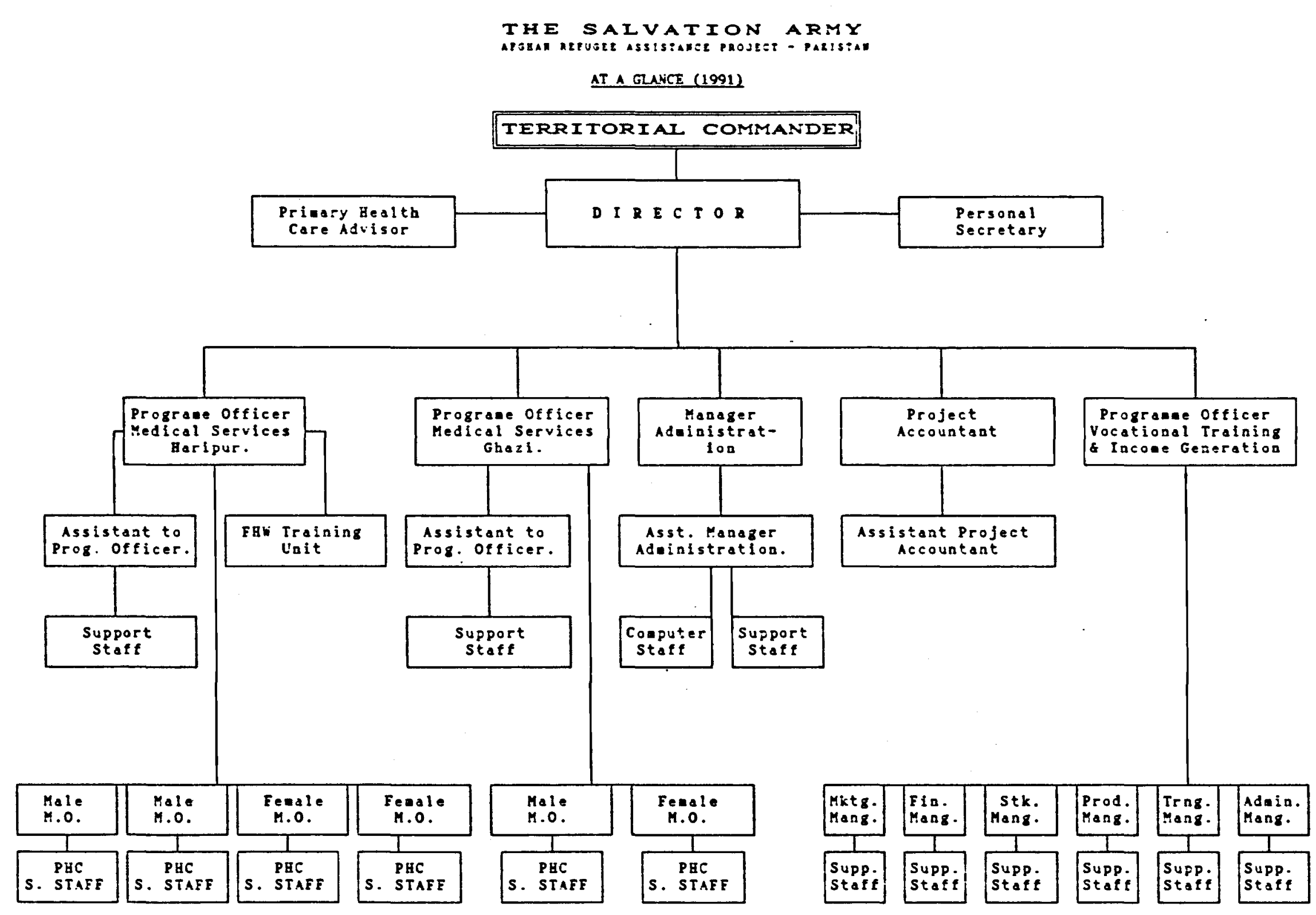


The reasons for the underspend in certain line items was due to the following:

a. STAFF BENEFITS

Instead of giving the uniform allowance @ Rs.1000.00 per staff member during the grant period, the project management decided to insure the staff against accidents and the cost of premium was Rs.500.00 per person for the full year insurance cover. By doing this the project managed to save Rs.75,000.00.

Another reason for the underspend was that the medical allowance was not fully utilised by the staff.

\section{b. STAFF TRAINING}

The money in this category was not fully utilized due to the non availability of the required management courses at Pakistan Institute of Management.

Also, due to the engagement of the Project Management with the transfer of the medical programme, fewer people were able to attend courses at Pakistan Institute of Management.

Finally, once again sincere thanks are extended to U.S State Department for their assistance with the funding of this project. 


\author{
THE SALVATION ARMY \\ Afghan Refugee Assistance Project \\ PAKISTAN
}

42

\title{
FUTURE PLANNING
}

WORK IN PAKISTAN

After transferring the medical programme, only the vocational training and income generation aspects of the programme are in operation being funded by $\mathrm{ICCO}$ and the EEC.

The objectives of The Salvation Army, Peshawar during the next year i.e from 1st May 1991 to 30th April 1992 are :

1] To facilitate the transfer of the medical programme to SCF(US).

2] To give technical assistance to ADA.

3] To implement Salvation Army / ICCO / EEC project.

To achieve these objectives, the Director will be assisted by the following staff: Manager. Administration. Project Accountant, Management Assistant, Personal Secretary, Computer Programmer and ancillary staff. These staff also form the Technical Assistance team and full details regarding this are in Annex 15 - "The Institutional Development and Provision of Technical Assistance to ADA by The Salvation Army. Peshawar."

\section{WORK IN AFGHANISTAN}

In December 1988, the Project Director prepared a concept paper regarding the idea of creating an indigenous Afghan NGO which could then go to Afghanistan and work to assist and encourage a repatriation of the refugees living in Pakistan, also assisting the internally displaced people who number about 2.3 million.

As mentioned earlier in this report, The Salvation Army has been able to create an indigenous Afghan NGO named the Afghan Development Association (ADA) in October 1990. This NGO has already received a No Objection Certificate from the Afghan Refugee Commissionerate and UNOCA office in Islamabad. Application has also been made for a No Objection Certificate from the Government of Pakistan States and Frontier Region, Islamabad. 


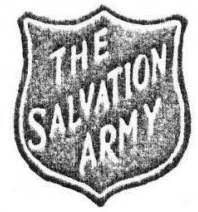

THE SALVATHOW ARMY

Afghan Refugee Assistance Project

PAKISTAN

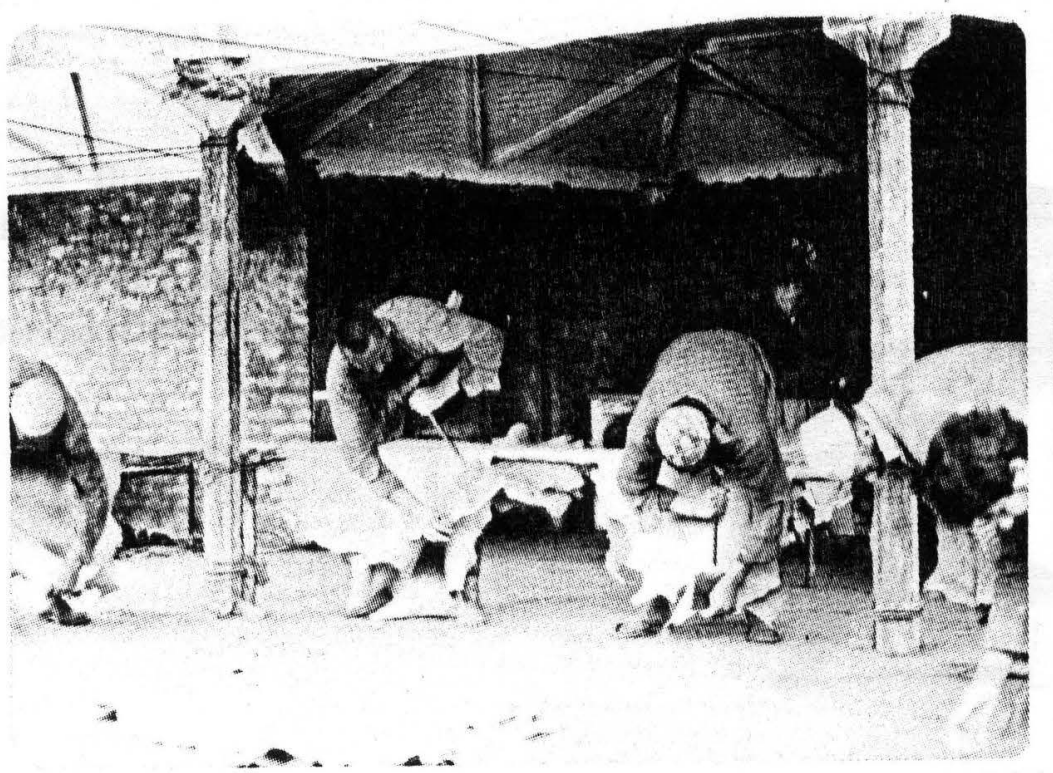

Preparation of skins for producton.

Dying the skins at the Haripur tannery.
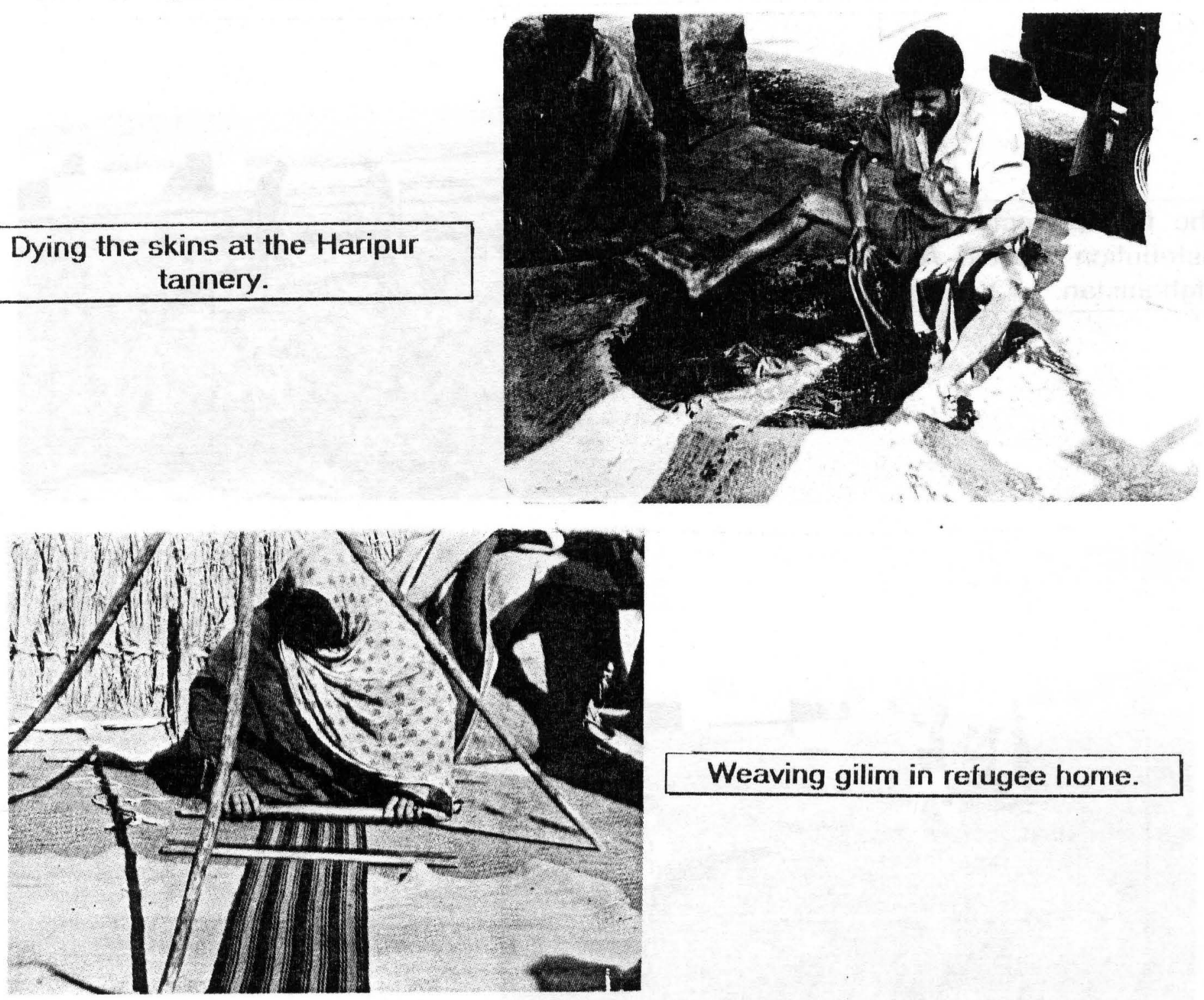

Weaving gilim in refugee home. 


\section{(rivinin}

THE SALVATIOU ARGY

\section{Afghan Refugee Assistance Project \\ PAKISTAN}

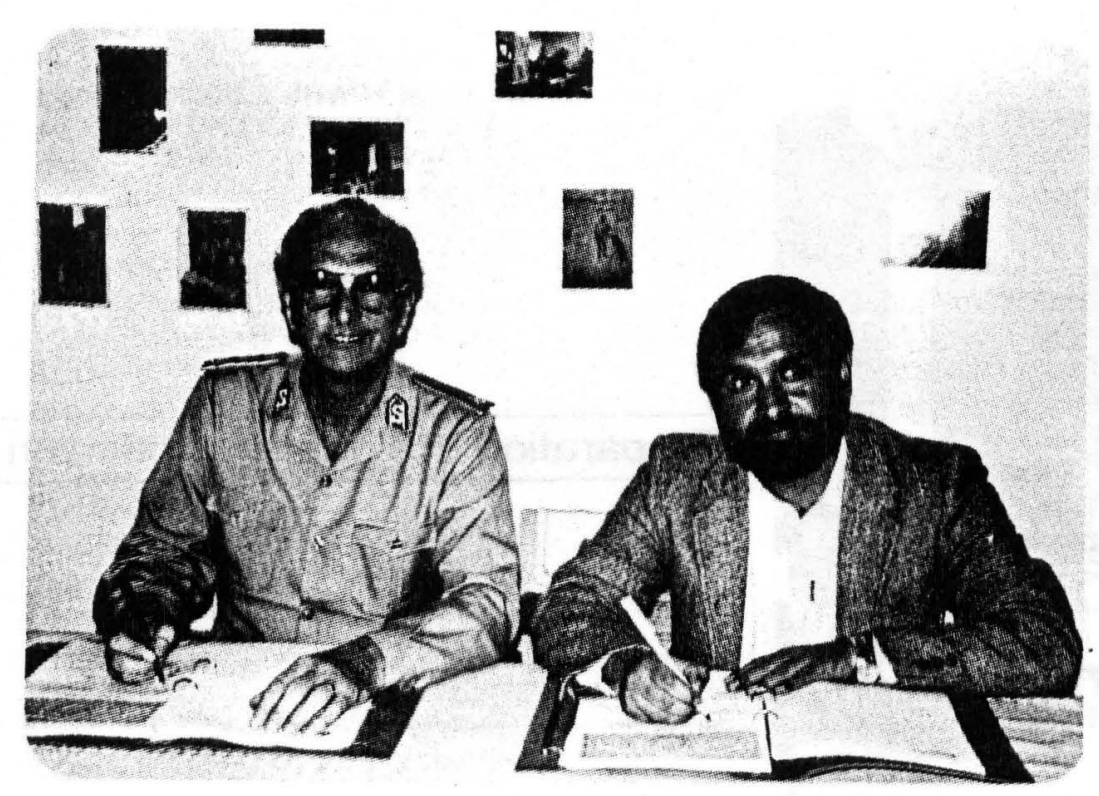

Colonel Nelson (T.C.) and Mr. Jelani signing the memorandum of understanding for the creation of the Afghan Development Association on 31 st Oct. 1990.

The first project, - improved seed distribution in Said Abad, Wardak, Afghanistan.
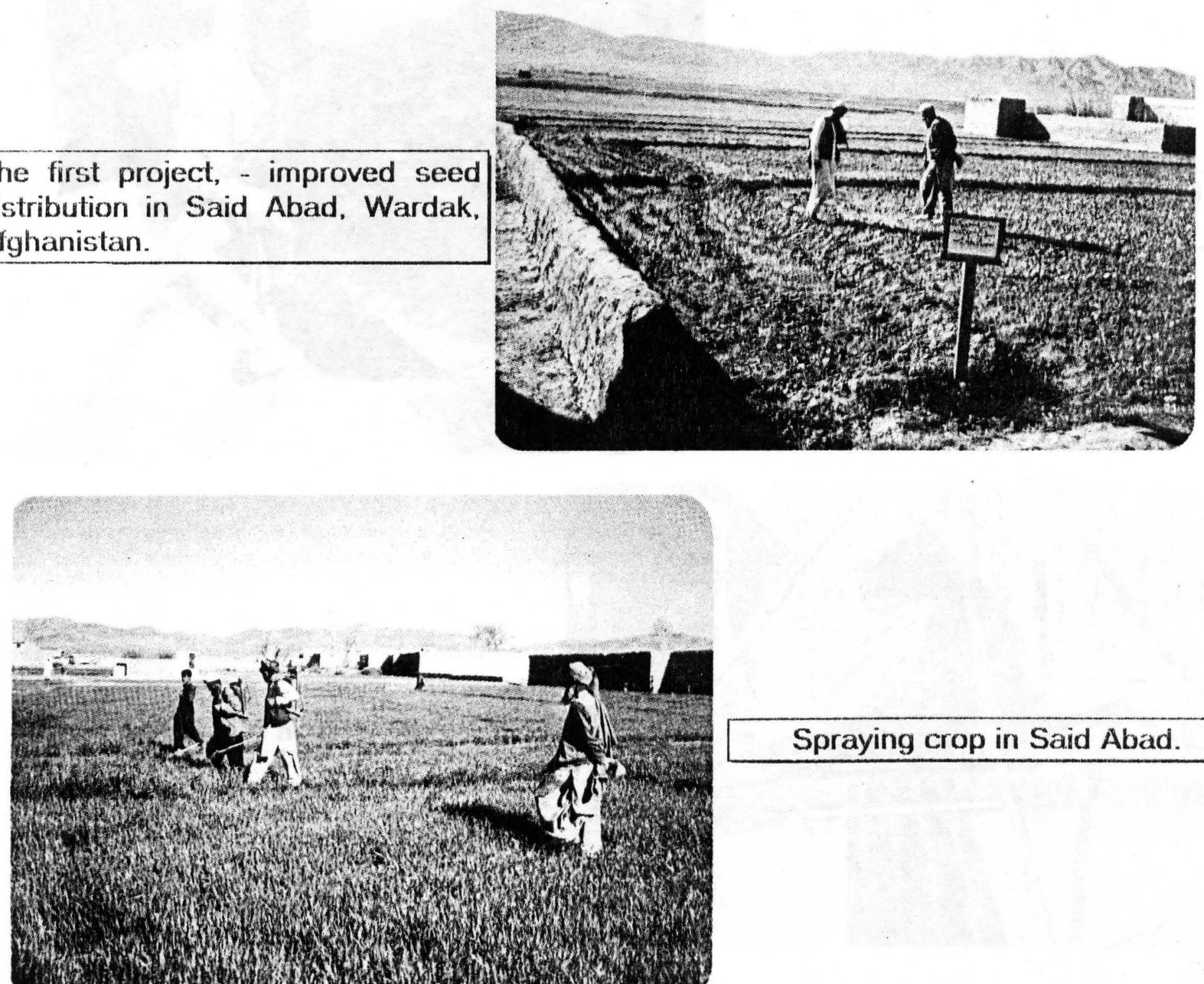

Spraying crop in Said Abad. 


\section{THE SALVATION ARMY \\ Afghan Refugee Assistance Project \\ PAKISTAN}

It was decided that, in the beginning, the staff of this NGO who are also The Salvation Army staff will implement the existing Salvation Army Vocational Training and Income Generation projects in the camps and will commence work as Afghan Development Association (ADA) in Afghanistan. After a period of two years, or earlier as mutually agreed by Salvation Army, the ADA will become independent and will implement all its own programmes.

This is detailed in the Memorandum of Understanding (MU) signed by The Salvation Army and ADA on 31st October 1990.

ADA and The Salvation Army have agreed to cease this MU on 31st October 1991 and from 1st November 1991, ADA will implement the vocational training and income generation projects in the camps on EEC funding which will be passed through Salvation Army.

Since February 1991, ADA has been implementing an agricultural rehabilitation project in Afghanistan and from May 1991, a survey project is underway. Other proposals are with donors and it is hoped further funding will soon follow.

It is the intention of ADA to attempt to be self supporting i.e eventually without donor funding and work is commencing in this regard in the income generation project.

In future, no one can predict with accuracy what will happen in Afghanistan, but one thing is certain, for many years the people will need much assistance. Let us give that assistance in an appropriate manner and let us enable the Afghans to help themselves.

\section{CONCLUSION}

Although The Salvation Army has now left the Medical programme and will be leaving the Vocational Training and Income Generation programme, the contribution of The Salvation Army will remain.

The Afghan people have not only been given assistance but have been encouraged and enabled to care for themselves as the Salvation Army's motivation during this project has been to assist people in need. 


\author{
THE SALVATIOH ARMY \\ Afghan Refugee Assistance Project \\ PAKISTAN
}

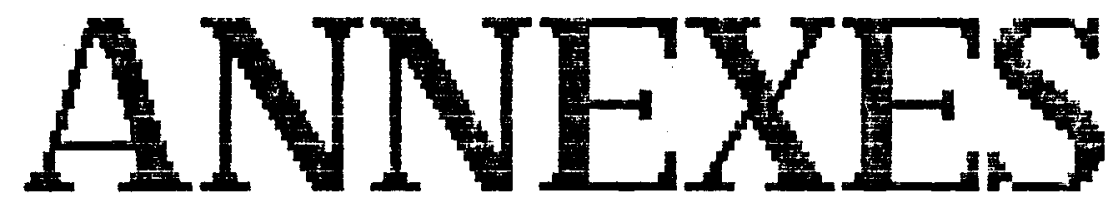




\section{LIST OF ANNEXES}

I. MEDICAL STATISTICS 46

II. LABORATORY STATISTICS 47

III. TUBERCULOSIS STATISTICS 48

IV. MALARIA SUPERVISORS REPORT 49

$\checkmark$ PREVENTINE HEALTH (ANTE NATAL) REPORT 50

V. PREVENTIVE HEALTH (UNDER TWO'S) REPORT 51

VII. E.P.I COMPLETION REPORT 52

VIII. E.P.I IMMUNIZATION STATUS REPORT

IX. PREVENTIVE HEALTH (MALE) STATISTICS 54

$X$ MINOR SURGERY REPORT

$X$. LIST OF MAJOR ASSETS TRANSFERRED TO SCF (US) $\quad 56-60$

$X I 1$. REVSED MEDICINE LIST $\quad 61,62$

XIII. INCOME AND EXPENDITURE ACCOUNTS AND BALANCE SHEETS FOR PD-734 (III) 63-65

XIV. EXPENDITURE ANALYSIS SHEET FOR THE 66 MONTH OF APRIL 1991

$X V$. INSTITUTIONAL DEVELOPMENT AND PROVISION OF TECHNICAL ASSISTANCE TO ADA BY THE SALVATIONARMY PESHAWAR. 
THE SALVATION ARMY

AFGHAN REFUGEE ASSISTANCE PROJECT

MEDICAL STATISTICS

Province

N.W.F.P

District/Agency:

ABBOTTABAD

RV: HARIPUR AND GHAZI BHU: $1,2,3,4,5 \& 6$

PERIOD: May' 90 to April 9

Organisation: The Salvation Army, Afghan Refugee Assistance Project.

\begin{tabular}{|c|c|c|c|c|c|}
\hline Nature of Sickness & Men & Women & \multicolumn{2}{|c|}{$0-4$ Children $4-15$} & Total \\
\hline Eye infection & 688 & 812 & 926 & 1121 & 3547 \\
\hline Ear infection & 376 & 525 & 1305 & 1313 & 3519 \\
\hline Upper respiratory infection & 7696 & 9086 & 11771 & 12302 & 40855 \\
\hline Bronchitis & 1605 & 3656 & 187 & 757 & 6205 \\
\hline T.B. suspected & 181 & 499 & 73 & 433 & 1186 \\
\hline T.B. confirmed & 255 & 380 & 2 & 12 & 649 \\
\hline Diarrhoea & 760 & 452 & 4813 & 2656 & 8681 \\
\hline Dysentery & 1168 & 982 & 3512 & 2566 & 8228 \\
\hline Worms & 603 & 440 & 678 & 2365 & 4086 \\
\hline other gastric problem & 2598 & 6226 & 2394 & 1803 & 13021 \\
\hline Urinary tract & 1251 & 1343 & 112 & 336 & 3042 \\
\hline Nervous system & 110 & 79 & 0 & 18 & 207 \\
\hline Joint/Bones & 992 & 730 & 30 & 122 & 1874 \\
\hline Skin disease & 3059 & 3390 & 3805 & 5932 & 16186 \\
\hline Malaria & 287 & 148 & 54 & 304 & 793 \\
\hline Fever (P.U.O.) & 1464 & 3871 & 4077 & 4806 & 14218 \\
\hline Anaemia & 562 & 1316 & 318 & 620 & 2816 \\
\hline Malnutrition: 1st Degree & - & - & 3127 & - & 3127 \\
\hline 2nd Degree & - & - & 1585 & - & 1585 \\
\hline 3rd Degree & - & - & 627 & - & 627 \\
\hline
\end{tabular}

Turn over please 


\begin{tabular}{|c|c|c|c|c|c|}
\hline Nature of Sickness & Men & Women & $0-4 \mathrm{Ch}$ & n $4-15$ & Tota 1 \\
\hline Obstetric & - & 10871 & - & - & 10871 \\
\hline Gynaecological & - & 3621 & - & - & 3621 \\
\hline Dental & 175 & 290 & 8 & 103 & 576 \\
\hline Psychosomatic illness & 4031 & 8724 & 8 & 815 & 13578 \\
\hline $\begin{array}{l}\text { Other (Specify if } \\
\text { notifiable)infections } \\
\text { disease. goitre i.e) }\end{array}$ & 1849 & 4240 & 448 & 649 & 7186 \\
\hline Measles & - & 3 & 32 & 22 & 57 \\
\hline Mumps & 1 & 3 & 4 & 15 & 23 \\
\hline Jaundice & 75 & 37 & 27 & 68 & 207 \\
\hline Typhoid & 21 & 23 & 0 & 36 & 80 \\
\hline Chicken Pox & - & - & - & 2 & 2 \\
\hline Tota 1 & 29807 & 61747 & 39923 & 39176 & 170653 \\
\hline
\end{tabular}

No. of referrals: 1183 patients referred to Govt: Hospitals from the BHUs 72513 patients referred to BHUs by the CHWs

178 birth certificates issued.

For further details please see enclosed reports

\section{Staff :}

Medical officer: 6 LHV : Compounder/Dispenser: Dai : 4

Malaria Supervisor/ Vaccinator/ Nursing Sanitary Inspector: $6 / 3$ Motivator: 7 orderly other 18

Traditional Birth Attendant (TBA)

TBA trainee/

Community Health Worker (CHW): 6/431 CHW trainee: 2

Ambulance: 1 other vehicles 4 Pajero Wagons, (Specify) 2 Toyota, 1 Ford Transist.

Date 


\section{THE SALVATION ARMY}

AFGHAN REFUGEE ASSISTANCE PROJECT

\section{LABORATORY STATISTICS}

Reporting Period May90-0ct91. Casp Haripur of Ghazi. BHU No: $1,2,3,4,5$ \& 6

\begin{tabular}{|c|c|c|c|c|c|}
\hline No. & Specieen & Tost Requested & Norral $/$-Ve & Abnorsal/t+Ve & Total \\
\hline \multirow[t]{9}{*}{1.} & \multirow[t]{9}{*}{ BLOOD } & T.L.C. + D.L.C. & 253 & 147 & 400 \\
\hline & & B.s.R. & 32 & 46 & $7 t$ \\
\hline & & Hbs & 71 & 62 & 133 \\
\hline & & vidal. & 203 & 94 & 297 \\
\hline & & M.P. & 18525 & 2141 & 20666 \\
\hline & & sugar. & - NIL - & 1 & 1 \\
\hline & & Group/Rh Pactor & 22 & - NIL - & 22 \\
\hline & & V.D.R.L. & - NIL - & - NIL - & - NIL - \\
\hline & & TOTAL & 19106 & 2491 & 21597 \\
\hline \multirow[t]{5}{*}{2.} & \multirow[t]{5}{*}{ URINE } & Cel1s. & 219 & 208 & 427 \\
\hline & & Sugar. & 105 & 12 & 117 \\
\hline & & Urobilinogin. & 113 & 12 & 125 \\
\hline & & Albusia & 53 & 178 & 231 \\
\hline & & Total & 490 & 410 & 900 \\
\hline \multirow[t]{2}{*}{3.} & \multirow{2}{*}{$\begin{array}{l}\text { SPUTUM } \\
\text { STOOL }\end{array}$} & A.P.B. & 2474 & 128 & 2602 \\
\hline & & R. Mora. & 60 & 4 & 64 \\
\hline \multirow{9}{*}{ 4. } & \multirow{9}{*}{. } & H. Wora. & 64 & 8 & 72 \\
\hline & & T. Wora. & 63 & 2 & 65 \\
\hline & & w. Wora. & 64 & 0 & 64 \\
\hline & & H. Nana. & 60 & 4 & 64 \\
\hline & & B. Histolytica. & 55 & 27 & 82 \\
\hline & & Occult Blood. & 61 & 3 & 64 \\
\hline & & Rutiac Bxas. & 52 & 7 & 59 \\
\hline & & Giardia. & 19 & 4 & 23 \\
\hline & & TOTAL & 498 & 59 & 5.57 \\
\hline \multirow[t]{3}{*}{5.} & \multirow[t]{3}{*}{ ANY OTHER } & Urine Pregnancy. & 125 & 63 & 180 \\
\hline & & Sesen Anelyais.. & 1 & 6 & 7 \\
\hline & & GRAND TOTAL & 22694 & 3157 & 250.51 \\
\hline
\end{tabular}

Rearks : 
BHU: $\quad 1,2,3,4,5 \& 6$ PERIOD May' 90 to April' 91.

DISTRICT : ABBOTTABAD

CAMP : Haripur \& Ghazi
AGENCY: The Salvation Army

Afghan Refugee Assistance Project

\section{A. CASE-FINDING ACTIVITIES BY MICROSCOPIC EXAMINATION}

\begin{tabular}{|c|c|c|c|c|}
\hline $\begin{array}{c}\text { Microscopy } \\
\text { Type of Patients }\end{array}$ & $\begin{array}{c}\text { Number } \\
\text { of slides } \\
\text { examined }\end{array}$ & $\begin{array}{c}\text { Number of } \\
\text { sides found } \\
\text { positive }\end{array}$ & $\begin{array}{c}\text { Number } \\
\text { of } \begin{array}{c}\text { patients } \\
\text { examined }\end{array}\end{array}$ & $\begin{array}{c}\text { Number of } \\
\text { patients } \\
\text { found positive }\end{array}$ \\
\hline $\begin{array}{c}\text { New attendants of } \\
\text { the clinic }\end{array}$ & 2252 & 96 & 854 & 39 \\
\hline $\begin{array}{c}\text { Under treatment } \\
\text { (old patients) }\end{array}$ & 350 & 32 & 142 & 14 \\
\hline Total & 2602 & 128 & 996 & 53 \\
\hline
\end{tabular}

B. TREATMENT ACTIVITIES

\begin{tabular}{|c|c|c|c|c|c|}
\hline \multirow[b]{2}{*}{ Cases } & \multirow[t]{2}{*}{ Type of disease } & \multicolumn{3}{|c|}{ No. of Pulmonary (P) cases } & \multirow{2}{*}{$\begin{array}{c}\text { No: of } \\
\text { Extra- } \\
\text { Pulmonary } \\
\text { Cases (EP) }\end{array}$} \\
\hline & & $\begin{array}{l}\text { Smear* } \\
\text { Positive }\end{array}$ & $\begin{array}{l}\text { Smear } \\
\text { Negative }\end{array}$ & Total & \\
\hline (a) & $\begin{array}{l}\text { Under treatment at the end } \\
\text { of previous period }\end{array}$ & 23 & 11 & 34 & 29 \\
\hline \multirow{3}{*}{ (b) $\begin{array}{r}\mathbf{n} \\
\mathbf{p} \\
\mathbf{u} \\
t\end{array}$} & $\begin{array}{l}\text { New cases registered during } \\
\text { this period }\end{array}$ & 38 & 40 & 78 & 28 \\
\hline & $\begin{array}{l}\text { starting again during this } \\
\text { month after being lost }\end{array}$ & 2 & - & 2 & - \\
\hline & $\begin{array}{l}\text { Transferred in during this } \\
\text { period }\end{array}$ & 3 & 1 & 4 & 4 \\
\hline (c) & Total input $=(a)+(b)$ & 66 & 52 & 118 & 61 \\
\hline \multirow{4}{*}{$\begin{array}{l}0 \\
u \\
t \\
p \\
u \\
t\end{array}$} & $\begin{array}{l}\text { Completing the treatment } \\
\text { during this period }\end{array}$ & 26 & 15 & 41 & 25 \\
\hline & Died during this period & 2 & 3 & 5 & - \\
\hline & $\begin{array}{l}\text { Transferred out during this } \\
\text { period }\end{array}$ & 4 & 2 & 6 & 2 \\
\hline & Lost during this period & 2 & - & 2 & 1 \\
\hline (d) & Total output & 34 & 20 & 54 & 28 \\
\hline (e) & $\begin{array}{l}\text { Under treatment at the end } \\
\text { of this period }=(\text { (c)-(d) }\end{array}$ & 32 & 32 & 64 & 33 \\
\hline
\end{tabular}

Note: Please, indicate the number of defaulters during this period. $p:(+) 2$ * Smear - positive in this column shall refer to patients. Whose sputa were positive at the start of treatment.

$(-) \frac{2}{-}$ EP: $\overline{2}$ 
THE SALVATION ARMY

AFGHAN REFUGEE ASSISTANCE PROJECT

MALARIA SUPERVISORS

REPORT FORM

Reporting Period May 90 to April 1991 Camp Haripur \& Ghazi BHU No: 1, 2, 3,4,5 \& 6

A. Malaria Control Activities:

\begin{tabular}{|c|c|c|c|c|c|c|c|}
\hline \multirow{2}{*}{$\begin{array}{c}\text { Total Slides } \\
\begin{array}{c}\text { Collected } \\
\text { Per Case })\end{array}\end{array}$} & \multicolumn{4}{|c|}{ Positive Case } & Negative & Cases & Un \\
\cline { 2 - 7 } & P.V & P.F & P.M & TOTAL & Cases & Treated & Treated \\
\hline 20666 & 1813 & 327 & 1 & 2141 & 18525 & 2141 & $-N i 1-$ \\
\hline
\end{tabular}

B. T.B. Control Activities:

Total Slides collected / Fixed: 


\section{THE SALVATION ARMY}

AFGHAN REFUGEE ASSISTANCE PROJECT

\section{PREVENTIVE HEALTH TEAM (FEMALE)}

Reporting Period May' 1990 - April'1991 Camp Haripur\& Ghazi _BHU NO: 1,2,3,4,5\& 6

Antenatal cinic

\begin{tabular}{|c|c|c|}
\hline $\mathbf{a}$ & Under care at the end of previous period. & 621 \\
\hline $\mathbf{b}$ & New cases registered this nonth. & 2213 \\
\hline c & Total $=(a+b)$ & 2834 \\
\hline \multirow{4}{*}{ d } & Live births during this period. & 2065 \\
\hline & stillbirths during this period. & 60 \\
\hline & Untraceable after e.d.d. & 53 \\
\hline & Tota 1. & 2178 \\
\hline $\mathbf{e}$ & Under care at the end of this period $=(c-d)$ & 656 \\
\hline
\end{tabular}

De 1 iveries

\begin{tabular}{|l|l|}
\hline Deliveries assisted by staff & 337 \\
\hline Deliveries assisted by T.B.A.S & 682 \\
\hline Deliveries assisted by F.H.W.S & 458 \\
\hline Total deliveries assisted & 1477 \\
\hline
\end{tabular}

\section{Mortality}

\begin{tabular}{|l|c|}
\hline Maternal deaths & 5 \\
\hline Infant deaths & 71 \\
\hline
\end{tabular}

Remarks: Defaultters at the end of period $=2$ 


\section{THE SALVATION ARMY}

AFGHAN REFUGEE ASSISTANCE PROJECT

PREVENTIVE HEALTH TEAM (FEMALE)

Reporting Period May' 90 to April'91. Camp Haripur \& Ghazi BHU No: 1,2,3,4,5, \& 6

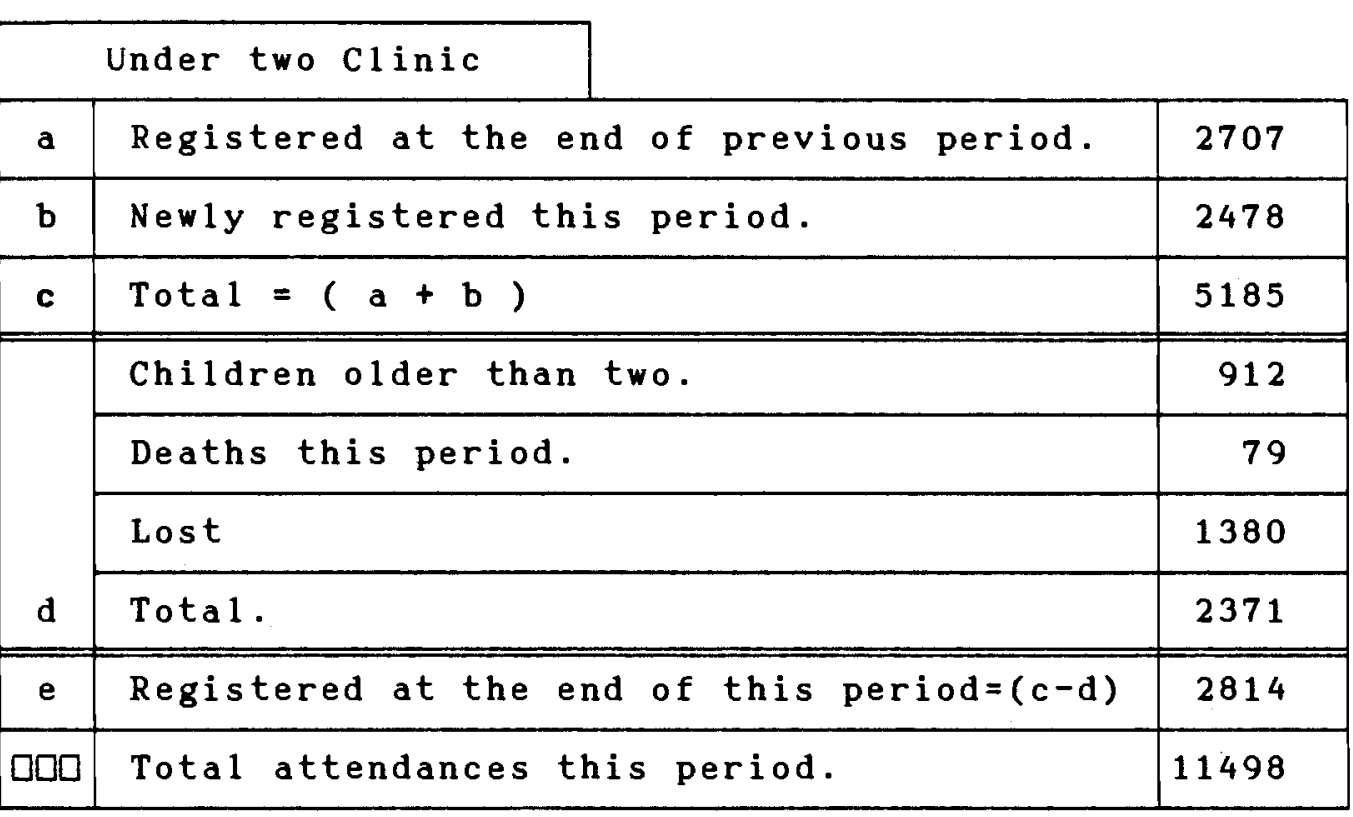

\begin{tabular}{|l|c|c|c|c|}
\hline Degree of malnutrition. & 1 st & 2nd & 3rd & Total \\
\hline Underwight no. & 324 & 132 & 50 & 506 \\
\hline Considerably improved. & 40 & 27 & 11 & 78 \\
\hline Defalters $\star$ & 37 & 20 & 11 & 68 \\
\hline
\end{tabular}

* Defaulter (healthy) if child misses two months (1st degree) if child misses one month (2nd degree) if child misses one month (3rd degree) if child misses two weeks

Remarks: Less students received health education as schools were closed for summer vacation

\begin{tabular}{|c|c|c|c|}
\hline Heal th & Education. & No. of attendances. & Number of lectures. \\
\hline \multicolumn{2}{|c|}{ Schools. } & 9303 & 135 Lectures. \\
\hline \multicolumn{2}{|l|}{ B.H.U. } & 106040 & 3627 Lectures. \\
\hline \multirow{4}{*}{$\begin{array}{l}\text { Home } \\
\text { Visits }\end{array}$} & Women & 35016 & \multirow{4}{*}{2454} \\
\hline & Antenata 1 & 3802 & \\
\hline & Postnata 1 . & 3581 & \\
\hline & Children. & 35026 & \\
\hline
\end{tabular}

Topics Covered: Weaning Food, Personal, T.B, Hygiene, Home Sanitation, Breast Feeding, Vaccination, Clean Water, Jaundice, Fever, Skin Infection, Care of New Born, Malaria, Immunisation, Diarrhoea, Growth Chart, Burns, Protection from Flies, Antinatal Diet, Worms, Postnatal care, Advantages of U-2 Cards, Danger of bottle feeding. 
THE SALVATION ARMY

AFGHAN REFUGEE ASSISTANCE PROJECT

EXPANDED PROGRAMME ON IMMUNISATION

VACCINATION COMPLETION REPORT

Reporting Period May' 90 to Apri1'91. Camp Haripur \& Ghazi BHU NO: 1,2,3,4,5\& 6

\begin{tabular}{|c|c|c|c|c|c|c|c|c|c|}
\hline \multirow{2}{*}{ Age Group } & \multirow{2}{*}{$\begin{array}{l}\text { Attendances } \\
\text { this period }\end{array}$} & \multicolumn{6}{|c|}{ Vaccination completed this period } & \multicolumn{2}{|c|}{$\begin{array}{l}\text { Conpletely } \\
\text { Vaccinated }\end{array}$} \\
\hline & & B.C.G. & $\begin{array}{l}\text { Po } 1 \text { io } \\
\text { III + Br }\end{array}$ & $\begin{array}{l}\text { D.P.T. } \\
\text { III+Br }\end{array}$ & $\begin{array}{l}\mathrm{D} \cdot \mathrm{T} \cdot \\
\mathrm{II}+\mathrm{Br}\end{array}$ & $\begin{array}{l}\mathbf{T} \cdot \mathbf{T} \\
\mathbf{I}+\mathbf{B r}\end{array}$ & Measles & $\begin{array}{c}\text { Period } \\
\text { Nov-Apr. }\end{array}$ & $\begin{array}{l}\text { Cumulative } \\
\text { Since May } 90\end{array}$ \\
\hline $\begin{array}{c}\text { Women } \\
(\mathrm{C} \cdot \mathrm{B} \cdot \mathrm{A})\end{array}$ & 8623 & 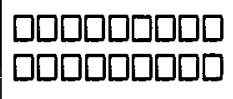 & 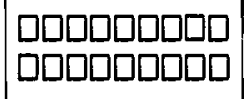 & 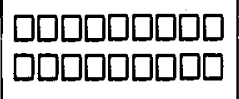 & 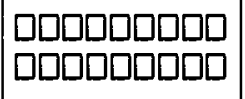 & 5818 & 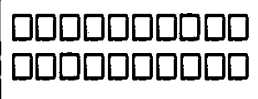 & 1237 & 2680 \\
\hline 12-23 Months & 204 & 19 & 150 & 150 & & & 35 & & 31 \\
\hline $2-4$ Years & & & & & & & & & \\
\hline $5+$ Years & & & & & & & & & \\
\hline TOTAL & 21675 & 2771 & 2868 & 2868 & & 5818 & 2618 & 2392 & 5285 \\
\hline
\end{tabular}


The Salvation Army

Afgban Refugee Assistance Project,

Pakistan PD - 734 (III).
Afghan Refugee Health Programe

Expanded Progranee on Ineunisation

1. Inmunisation preforned during November' 90 to April, 91 . BHU

MONTHLY REFORT

\begin{tabular}{|c|c|c|c|c|c|c|c|c|c|c|c|c|c|c|c|c|c|c|}
\hline \multirow{2}{*}{ Age Group } & \multirow{2}{*}{$\begin{array}{c}\text { POLIO } \\
0\end{array}$} & \multirow{2}{*}{ B.C.G } & \multicolumn{4}{|c|}{ POLIO } & \multicolumn{4}{|c|}{ D.P.T. } & \multicolumn{5}{|c|}{ T.T. } & \multirow{2}{*}{ Measles } & \multirow{2}{*}{$\begin{array}{c}\text { Total } \\
\text { atte- } \\
\text { nd. }\end{array}$} & \multirow{2}{*}{$\begin{array}{l}\text { F.I. } \\
\text { U.1. }\end{array}$} \\
\hline & & & $\mathbf{I}$ & I I & I II & Br. & $\mathbf{I}$ & II & I I I & $\mathrm{Br}$. & I & I I & III & IV & $\mathbf{v}$ & & & \\
\hline 0-11 Months & 940 & 1487 & 1465 & 1456 & 1345 & - & 1465 & 1456 & 1345 & - & - & - & - & - & - & 1154 & 6541 & 1155 \\
\hline 12-23 Months & - & 2 & 2 & 3 & 5 & - & 2 & 3 & 5 & - & - & - & - & - & - & 2 & 10 & - \\
\hline 2-4 Years & - & - & - & - & - & - & - & - & - & - & - & - & - & - & - & - & - & - \\
\hline $5+$ Years & - & - & - & - & - & - & - & - & - & - & - & - & - & - & - & - & - & - \\
\hline Woren $(15-45)$ & - & - & - & - & - & - & - & - & - & - & 1158 & 1237 & 614 & 675 & 162 & - & 3846 & - \\
\hline Total & 940 & 1489 & 1467 & 1459 & 1350 & - & 1467 & 1459 & 1350 & - & 1158 & 1237 & 614 & 675 & 162 & 1156 & 10397 & 1155 \\
\hline
\end{tabular}

2. Uptodate work done since May' 1990 todate during the current project PD 734 (III).

\begin{tabular}{|c|c|c|c|c|c|c|c|c|c|c|c|c|c|c|c|c|c|c|}
\hline $0-11$ Months & 1720 & 2750 & 2734 & 2748 & 2711 & - & 2734 & 2748 & 2711 & - & - & - & - & - & - & 2581 & 12838 & 2574 \\
\hline 12-23 Months & - & 21 & 22 & 24 & 29 & 126 & 22 & 24 & 29 & 126 & - & - & - & - & - & 37 & 214 & 4 \\
\hline \multicolumn{19}{|l|}{ 2-4 Years } \\
\hline \multicolumn{19}{|l|}{$5+$ Years } \\
\hline Wonen $(15-45)$ & & & & & & & & & & & 2800 & 2670 & 1808 & 1167 & 173 & - & 8623 & - \\
\hline Total & 1720 & 2771 & 2756 & 2772 & 2740 & 126 & 2756 & 2772 & 2740 & 126 & 2800 & 2670 & 1808 & 1167 & 173 & 2618 & 21675 & 2578 \\
\hline
\end{tabular}

Signature

Progranme officer. 


\section{THE SALVATION ARMY}

AFGHAN REFUGEE ASSISTANCE FROJECT

PREVENTIVE HEALTH TEAM (MALE)

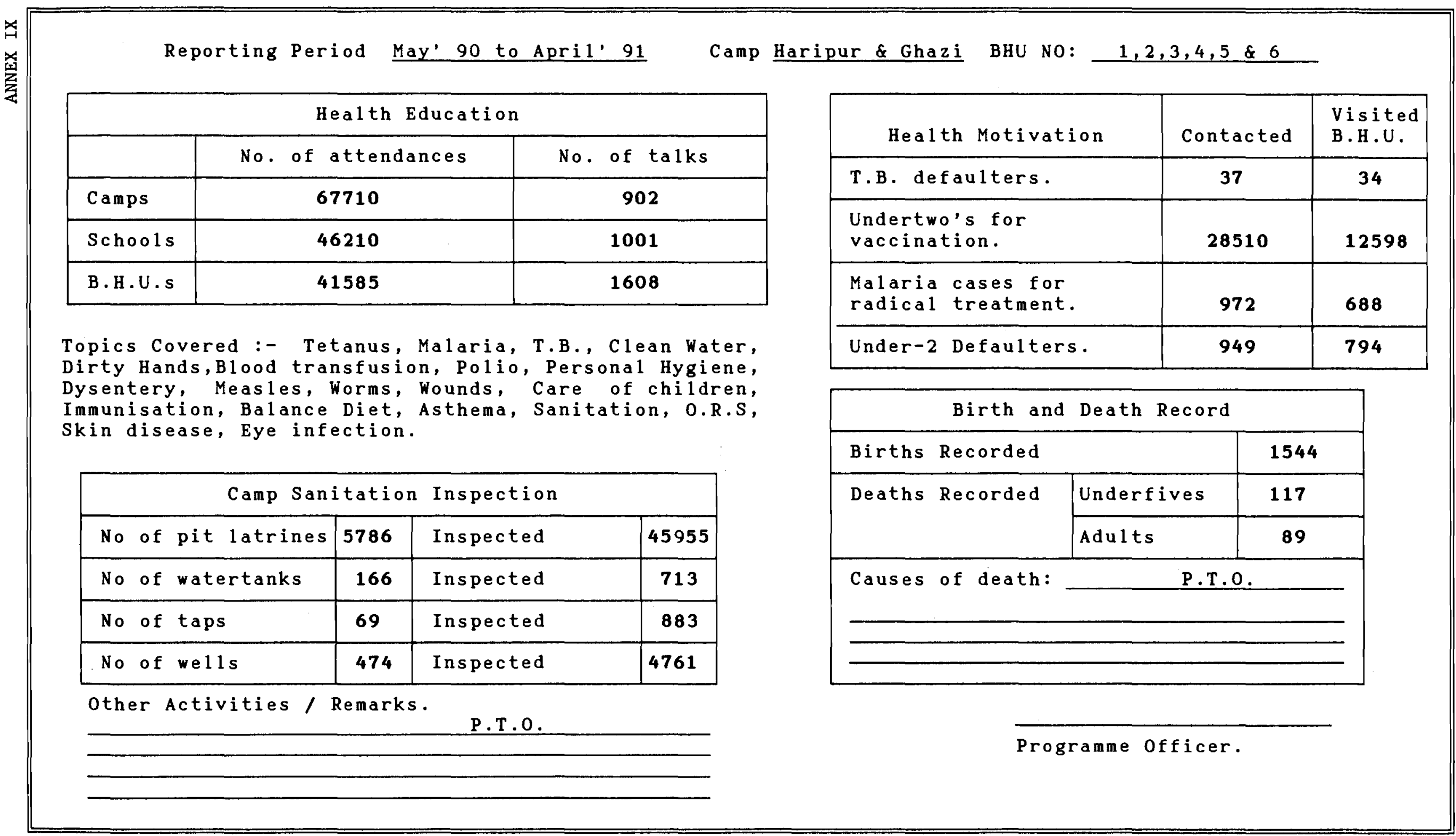




\section{UNDER FIVE}

\begin{tabular}{lr} 
1. Weakness & 2 \\
2. After birth & 11 \\
3. Sun Stroke & 7 \\
4. Gastro ententies & 23 \\
5. Diarrhoea & 8 \\
6. Pneumonia & 18 \\
7. Jaundice & 7 \\
8. Chest infection & 2 \\
9. Premature & 7 \\
10. Drowned & 1 \\
11. Fever & 3 \\
12. Unknown & 19 \\
13. Dysentry & 1 \\
14. Postoperative & 1 \\
15. Re Tract cost & 1 \\
16. Rabid dog & \\
17. Tetanus & 1 \\
18. During birth & 3 \\
19. R.T.I. & 1 \\
\hline
\end{tabular}

ADULTS

\begin{tabular}{|c|c|}
\hline $\begin{array}{l}\text { Rabies } \\
\text { Stomach Problem } \\
\text { Epilepsy } \\
\text { Head injuries } \\
\text { old age } \\
\text { Weakness } \\
\text { Hemi } \\
\text { Heart attack } \\
\text { Hyper tension } \\
\text { Cancer } \\
\text { Bronchial Asthma } \\
\text { Fever } \\
\text { Sun Stroke } \\
\text { Accident } \\
\text { During Delivery } \\
\text { Unknown } \\
\text { Nepratic syndown } \\
\text { Diarrhoea } \\
\text { Fever } \\
\text { Pyschosis } \\
\text { Intestimal obst } \\
\text { Natural } \\
\text { Drowned } \\
\text { Peptic ulcer } \\
\text { Suffocation } \\
\text { Prospectire in } \\
\text { Peshawar Hospital } \\
\text { Tubet culosis } \\
\text { Asthoma } \\
\text { Dog bite } \\
\text { Jaundice } \\
\text { Cardiac Failure } \\
\text { Felamfisia }\end{array}$ & $\begin{array}{r}1 \\
1 \\
1 \\
2 \\
4 \\
4 \\
1 \\
4 \\
3 \\
1 \\
5 \\
3 \\
1 \\
9 \\
1 \\
20 \\
1 \\
1 \\
2 \\
1 \\
1 \\
4 \\
1 \\
1 \\
1\end{array}$ \\
\hline & \\
\hline
\end{tabular}

OTHER ACTIVITIES
1. General shops inspected
2. Butchers' shops inspected
3. Wells chlorinated
4. Ditches closed
5. Children referred for vaccination
6 Patients referred for sputum
1259 Examination
7. Killed rabied dogs
8. Referred from CHW to BHW
9. Referred from BHU to CHW
10. Referred from CHS to U/2 clinic 166
11. No. of CHW's visited by their respective CHS's 


\section{THE SALVATION ARMY}

\section{AFGHAN REFUGEE ASSISTANCE PROJECT}

MEDICAL STATISTICS (MimOR SUMGEMU)

Reporting Period May' 90 to April' 91 Cap Haripur \& Ghazi BHU No: 1,2,3,4,5\&6 Total Number of Attendances 27028

Minor Surgery

\begin{tabular}{|c|c|c|c|c|c|}
\hline Injections & $\begin{array}{c}\text { Wound } \\
\text { Dressing }\end{array}$ & $\begin{array}{c}\text { Burns } \\
\text { Dressing }\end{array}$ & $\begin{array}{c}\text { Abscess } \\
\text { I / D }\end{array}$ & Stitching & Total \\
\hline 13615 & 17172 & 921 & 500 & 80 & 32288 \\
\hline
\end{tabular}

Circuecisions: 60

Ear Wash:

Remarks : 


\section{THE SALVATION ARMY Afghan Refugee Assistanče Project \\ 34-C/3A-1, Circular Ruad, University Town, Peshawar, N.W.F.P. PAKISTAN}

Universily P.O. Box 922

Telephones (0.521) 42230, 44779

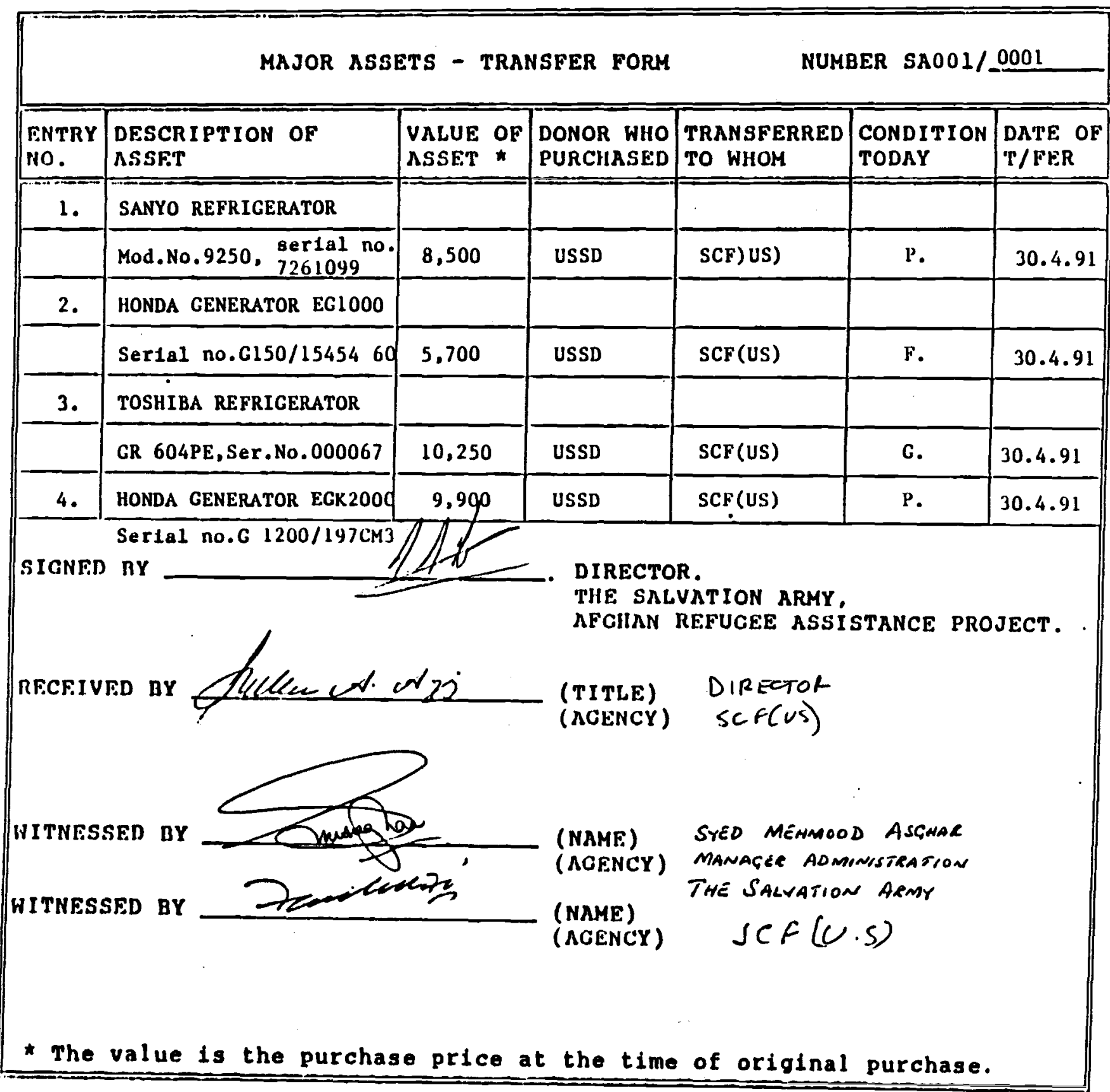




\section{THE SALVATION ARMY Afghan Refugee Assistance Project 34-C/3A-1, Circular Road, University Town, Peslawar, N.W.F.P. PAKISTAN}

University P.O. Box 922

Telephunes (0521) 42230, 44779

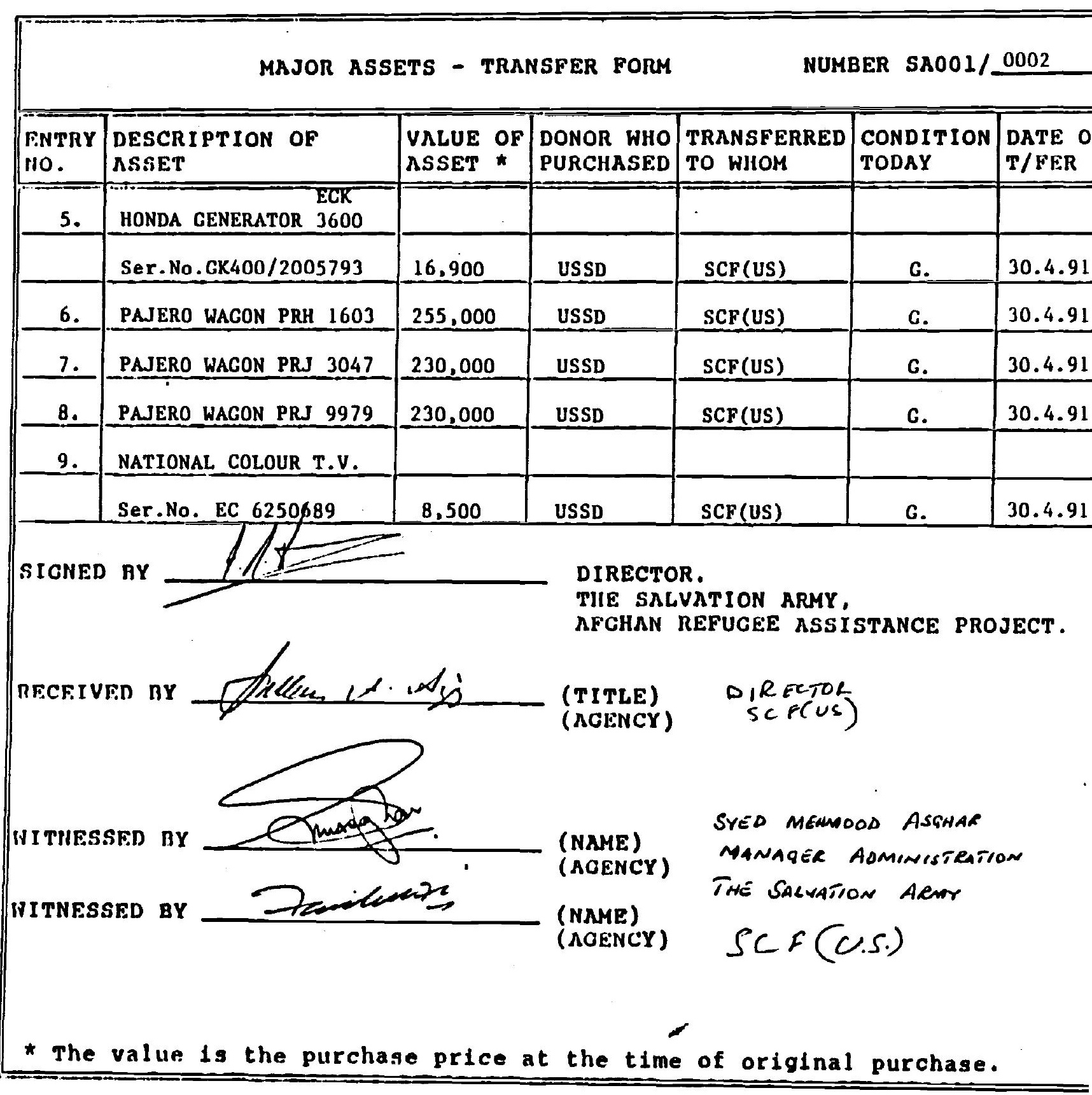


THE SALVATION ARMY

Afghan Refugee Assistanice Project

34-C/3A-1, Circular Road, University Towil, Peshawar, N.W.F.P. PAKISTAN

University P.O. Box 922

Telephones (0521) 42230, 44779

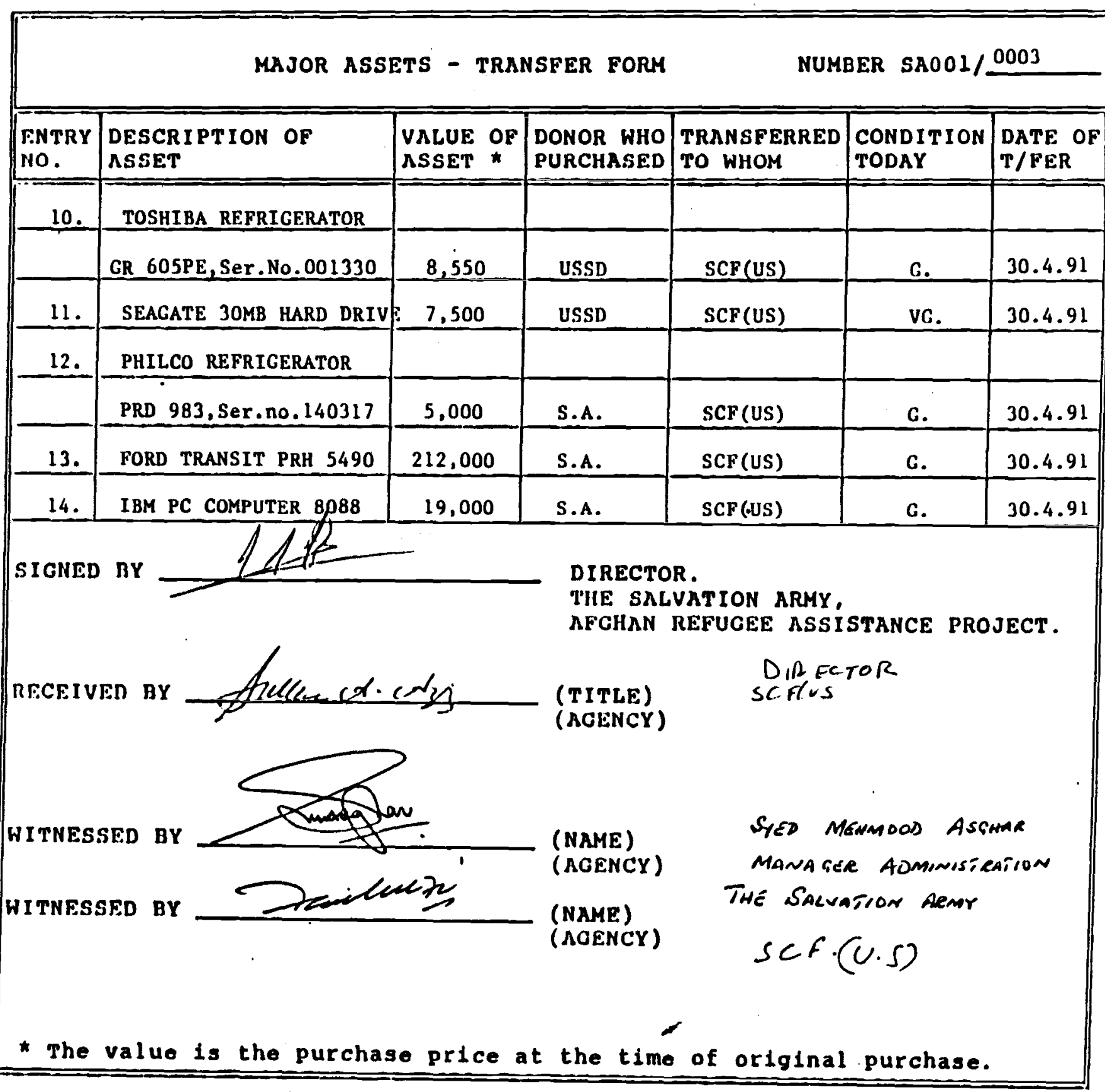

WILLIAM BOOTH, Founder EVA bURROWS, Generul FARMAN MASIH, Territorial Commander 


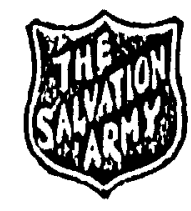

\section{THE SALVATION ARMY Afghan Refugee Assistance Project}

34-C/3A-1, Circular Road, Universily Towlı, Peslawar, N.W.F.P. PAKISTAN

Universily P.O. Box 922

'Telephoncs (0521) 42230, 44779

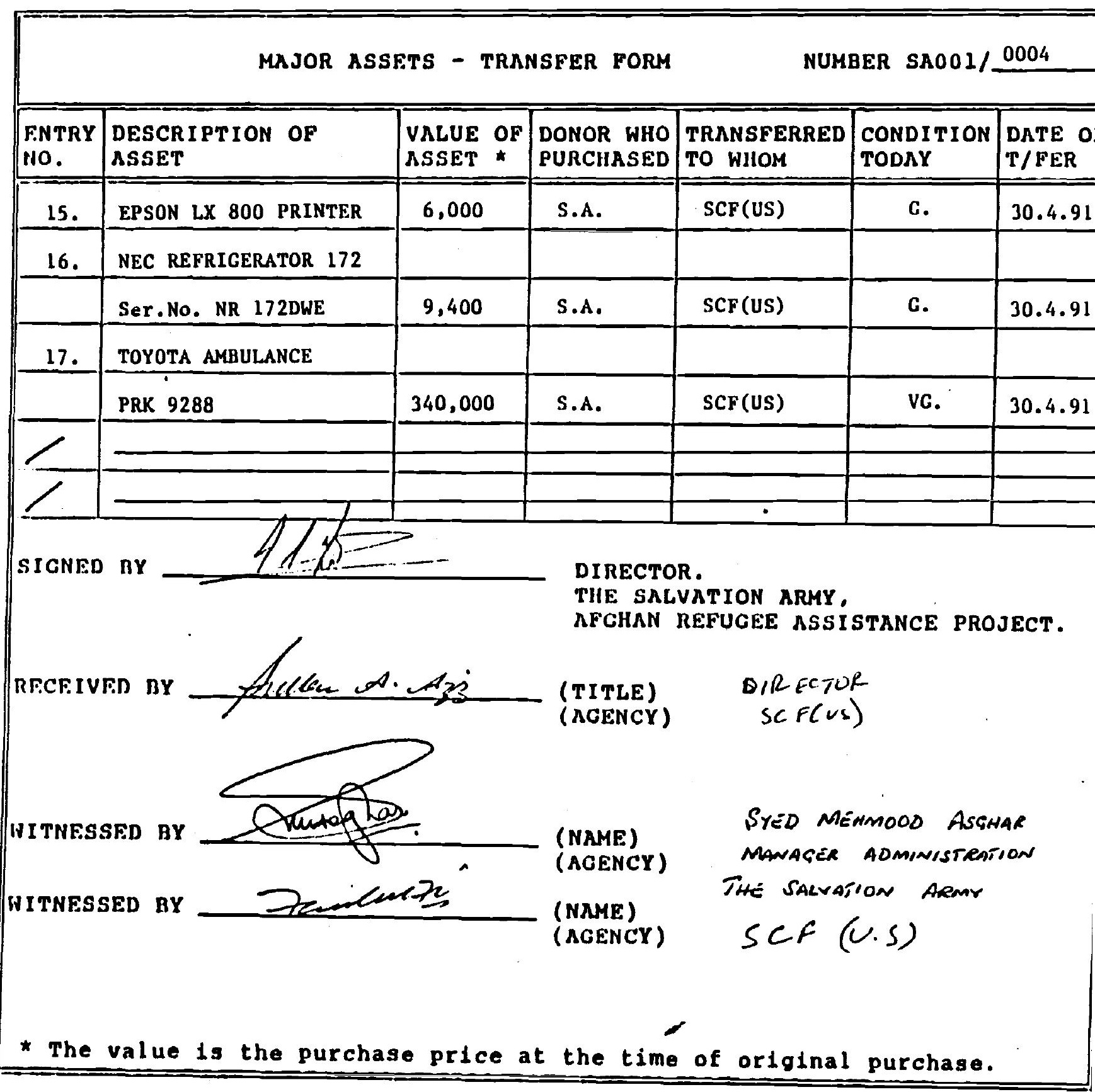




\section{THE SALVATION ARMY Afghan Refugee Assistanice Project}

34-C/3A-1, Circular Road, University 'Town, Peshawar, N.W.F.P. PAKISTAN

Universily P.O. Box 922

Telephones (0.521) 42230, 44779

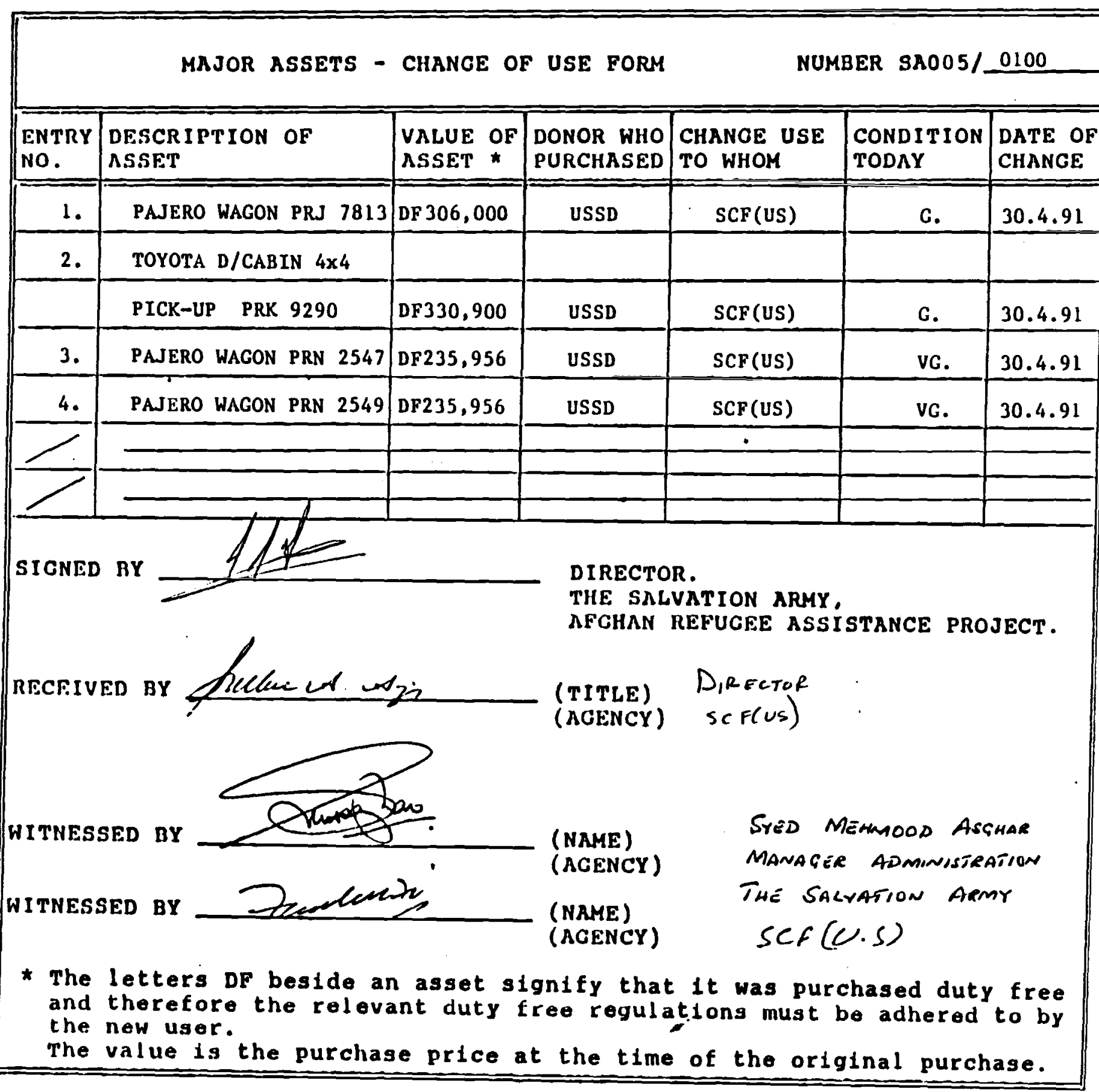

WILLIAM BOOTH, Founder EVA IJURROWS, Gentral FARMAN MASIII, Turrutonial Comminder 
Mediciue list.

\begin{tabular}{|c|c|c|c|}
\hline S. $V_{0}$ & Mans of nBOIGIUR & s.110 & MAIIR OP URAICIYS \\
\hline 1. & Capsule Lasill (Jeectar) 250 af. & 20. & fablets Veatolin (Leal) $100 \mathrm{et}$. \\
\hline 2. & Pablets Co-Prinesaule. (Local) & 21. & Syrup Veatolis (Glaro). $60 \mathrm{al}$ \\
\hline 3. & Syrup Septron. (Yellcone) & 21. & Pander Cicatrin. \\
\hline 1. & Pablets Pesicillin Y. 250 at (Glaso) & 29. & Crean Intual (loots) 30 eg. \\
\hline g. & Syrup Onipes (Inperted) & 30. & Dinteat letaruate (Glaz) $15 \mathrm{ag}$. \\
\hline 6. & Draps Lapiclos (Jeechan) 1 al. & 31. & Diatnent (Hycota) $21 \mathrm{~g}$. \\
\hline 1. & Tablets Irufen (becal) $100 \mathrm{af}$. & 32. & golution Lscabial (l) 1 I). \\
\hline I. & rablets Paracetanel (Vichalas). & 39. & fablets Lvil (Heechet) $25 \mathrm{ag}$. \\
\hline 9. & Tablets Ispirin. & gi. & Syrup Pheersa (il 1 ). \\
\hline 10. & fablets latifed (Nelleme). & 35. & rablets Deltacortil (Pfizer) s as. \\
\hline 11. & Draps lipcale (901) & 36. & Tablets Ildenet (USD) $250 \mathrm{ug}$. \\
\hline 12. & Pablets Iesuchin (layer) $250 \mathrm{at}$. & 31. & Pablets Inderal (ICI) 10 if. \\
\hline 13. & Syrup Chlaraquin (Mabi pasia). & j1. & Tablets Moduretic. \\
\hline 14. & Tablets irisil (Pfrase) $500 \mathrm{~g}$. & 39 & Tablets Diacepu (leported) g ig. \\
\hline 15. & visture Corninative (Jliss). & 40. & rablets Phenobarbitone (fernze sons) 30 ag. \\
\hline 16. & Poblets Jyescine Conpoud. & 41. & Tablets Griseren $0.25 \mathrm{ig}$. \\
\hline 17. & Pablets intes (Iryeth). & 12. & tablets Dulcalat (Inetrifer) 5 ag. \\
\hline 11. & Pablats flaegl (I \& I) $200 \mathrm{as.}$ & 43. & Syrup sodiu Leid Citrote 120 ag. (Local) \\
\hline 19. & Syrup Netronidatole. (bocal) & 14. & Tablets Vilstat Viginal (Lederle). \\
\hline 20. & Tablets conbontrais (Pfizer) $250 \mathrm{of}$. & & betion Geation Vielet. $150 \mathrm{al}$. \\
\hline 21. & Inspensin Conbutrie (Pfizer). & & Lotion Geation Violet. $30 \mathrm{al}$ \\
\hline 12. & fablets Ivain (II \& I). & 16. & Tablets Methergin (Sandos) $0.125 \mathrm{at}$. \\
\hline 19. & Syrug Maznlon (Jeectua). & 19 & fablets Perrous Sulphate (Glaro). \\
\hline 21. & Syru Jenadryl Itp. (Parte Davis). & 11. & syrup Multivitinis $120 \mathrm{af}$. \\
\hline 25. & Syru) Lheanl Plus (Popular). & 49. & Tablets Polic Leid (Yabi pasia). \\
\hline
\end{tabular}


Medicine List.

\begin{tabular}{|c|c|c|c|}
\hline s.110 & HAHB of MEDICINS & 9.10 & ULKP OP ABDICIUE \\
\hline so. & Tablets I Canpoud (Perase ins). & 75. & Meliyluted spirit. \\
\hline si. & Pollets ostocolein (closo). & \multirow{3}{*}{96.} & \multirow{3}{*}{$\begin{array}{l}\text { Sovolos solution } \\
\text { Dottol. } \\
\text { Dettol. }\end{array}$} \\
\hline 52. & Draps Polivti (pol). & & \\
\hline sj. & Dintaent ferrungcin lye (lported). & & \\
\hline S4. & Drops otesuris bar (Velleme). & 11. & Syrup Calpol (Melleone). 120 al. \\
\hline 5s. & Chloronphenical Dar drops. & i1. & Disposable syringes (s c.ce) \\
\hline s6. & Chloraphenical lye drops. & 99. & Dispesoble syrieges (s c.c.) \\
\hline 39. & Iydensal solt (0tg). & 10. & Disposable syringer (10 c.c.) \\
\hline si. & Injection Inpicilline 250 ef. (lnported) & 11. & Cotton rool. \\
\hline s9. & Injection Procoin Ponicillis (Ifizer)400000 & 12. & Guose thous. \\
\hline 6. & Injectin Iyorcine s al. & is. & lirst aid plaster (landopes). \\
\hline 61. & Injection Lvil (Hoechst) \& al. & 14. & Indeges $(6 \%)$ \\
\hline 63. & Lijectin dninopylline (chind) 10 al. & 19. & Iondoges (3\%). \\
\hline 63. & Injection Methergin (Sondos) I al. & 16. & sticking Plaster $(\mathrm{J})$. \\
\hline 64. & lnjectin bosit (loechet) a al. & 17. & Itbyl chloride sproy. \\
\hline 65. & Injection Vunolan (Iection) z al. & u. & Vicroscopic slides. \\
\hline 66. & Injectin Dlosepon (10 at) 2 al. (lnported) & 19. & Surfical Jlades. \\
\hline เ1. & lojectin L.r.s (lliva) 1500 in. & io. & Stiching Moterial. \\
\hline it. & Lujection Idernaline (llorter) I al. & 91. & Distilled neter for lajection. \\
\hline 69. & Lujectin Decodars (aso) 1 es. (2 al). & 92. & Paracetual tab. \\
\hline 70. & lajectlon sesefon (Vintirn)) I al. & & \\
\hline 11. & Injection Iylocoine (Lecal) 21 so al. & & \\
\hline 11. & Injection Deztrose (china) $25 \mathrm{t} 20 \mathrm{al}$. & & \\
\hline i3. & Injection Dertrose Vater (china) $581000 \mathrm{Al}$ & & \\
\hline 14. & Injectin Destruse Saline (chine) $1000 \mathrm{al}$ & & \\
\hline
\end{tabular}


THE SAIVATION ARMY

Afghan Refuget Astatace project

INCOME AND EXPENDITURE ACCOUNT

PD - 734 III S.A.W.S.O.

From May 1, 1990 to April 30, 1991.

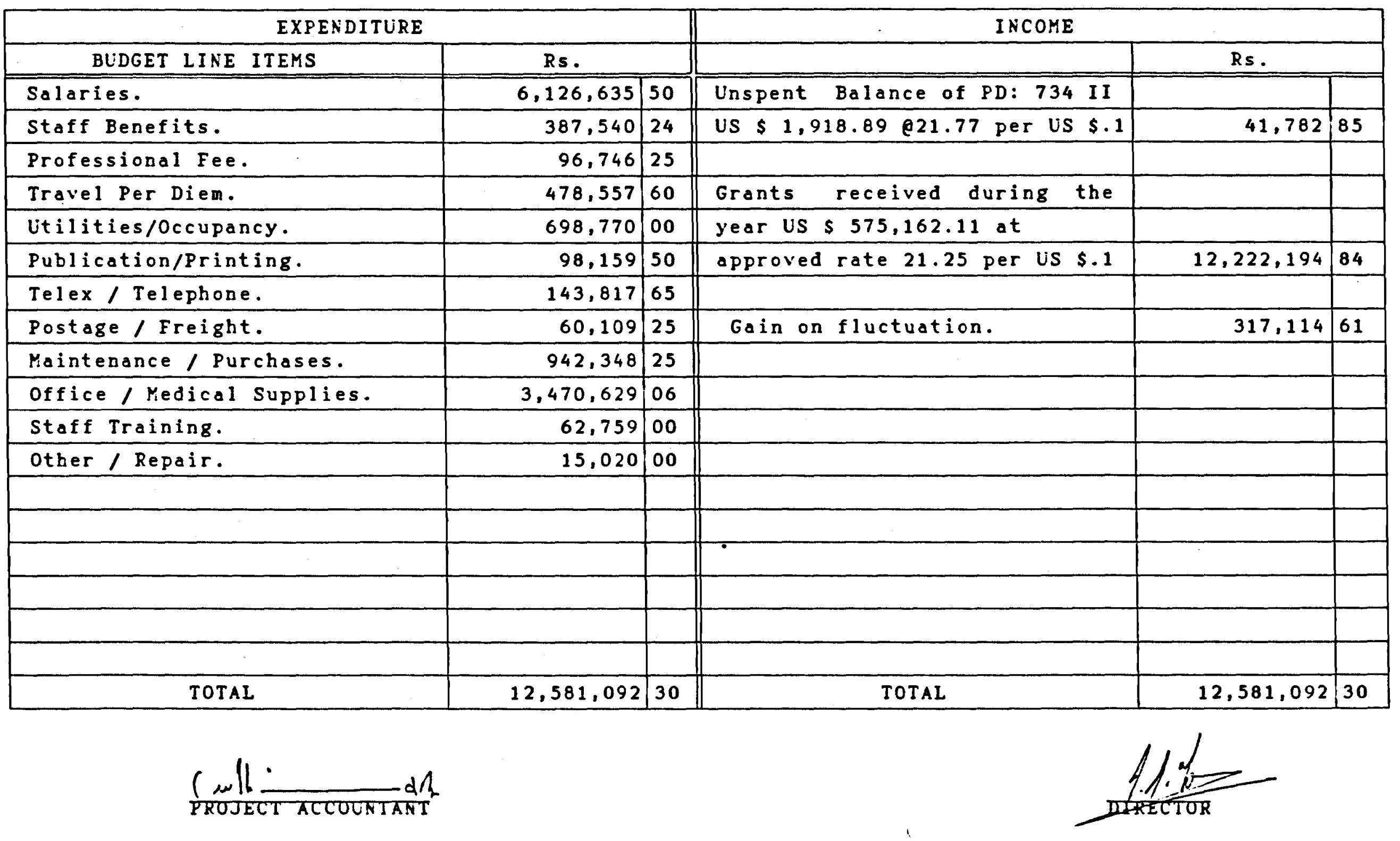


THE SAIVATION ARMY

A Ehad FefUECe AESEtode Project

INCOME AND EXPENDITURE ACCOUNT

PD - 734 III S.A.W.S.O.

From October 1, 1990 to April 30, 1991.

\begin{tabular}{|c|c|c|c|c|c|c|}
\hline \multicolumn{3}{|c|}{ EXPENDITURE } & \multicolumn{4}{|c|}{ INCOME } \\
\hline BUDGET LINE ITEMS & \multicolumn{2}{|l|}{ Rs. } & & & \multicolumn{2}{|l|}{ Rs. } \\
\hline Salaries. & $4,162,913$ & 50 & Unspent Gront from & 30 th SEP- & & \\
\hline Staff Benefits. & 280,272 & 95 & tember, 1990. & & 325,741 & 49 \\
\hline Professional Fee. & 60,746 & 25 & & & & \\
\hline Travel Per Diem. & 326,707 & 50 & Grants received & from SAKSO & & \\
\hline Utilities/occuponcy. & 586,043 & 00 & during the period. & & $7,897,814$ & 57 \\
\hline Publicotion/Printing. & 93,329 & 50 & & & & \\
\hline Telex / Telephone. & 105,441 & 75 & & & & \\
\hline Postoge / Freight. & 44,090 & 75 & & & & \\
\hline Maintenance / Purchoses. & 728,155 & 25 & & & & \\
\hline Office / Medical Supplies. & $1,783,728$ & 61 & & & & \\
\hline Staff Training. & 42,024 & 00 & & & & \\
\hline other / Repair. & 10,103 & 00 & & & & \\
\hline & & & - & & & \\
\hline & & & & & & \\
\hline & & & & & & \\
\hline & & & & & & \\
\hline & & & & & & \\
\hline TOTAL & $8,223,556$ & 06 & TOTAL & & $8,223,556$ & 06 \\
\hline
\end{tabular}


THE SAIVATION ARMY

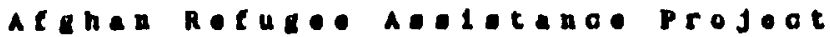

BALANCE SHEET

PD: 734 III S.A.W.S.O.

As at 30th Apr11, 1991.

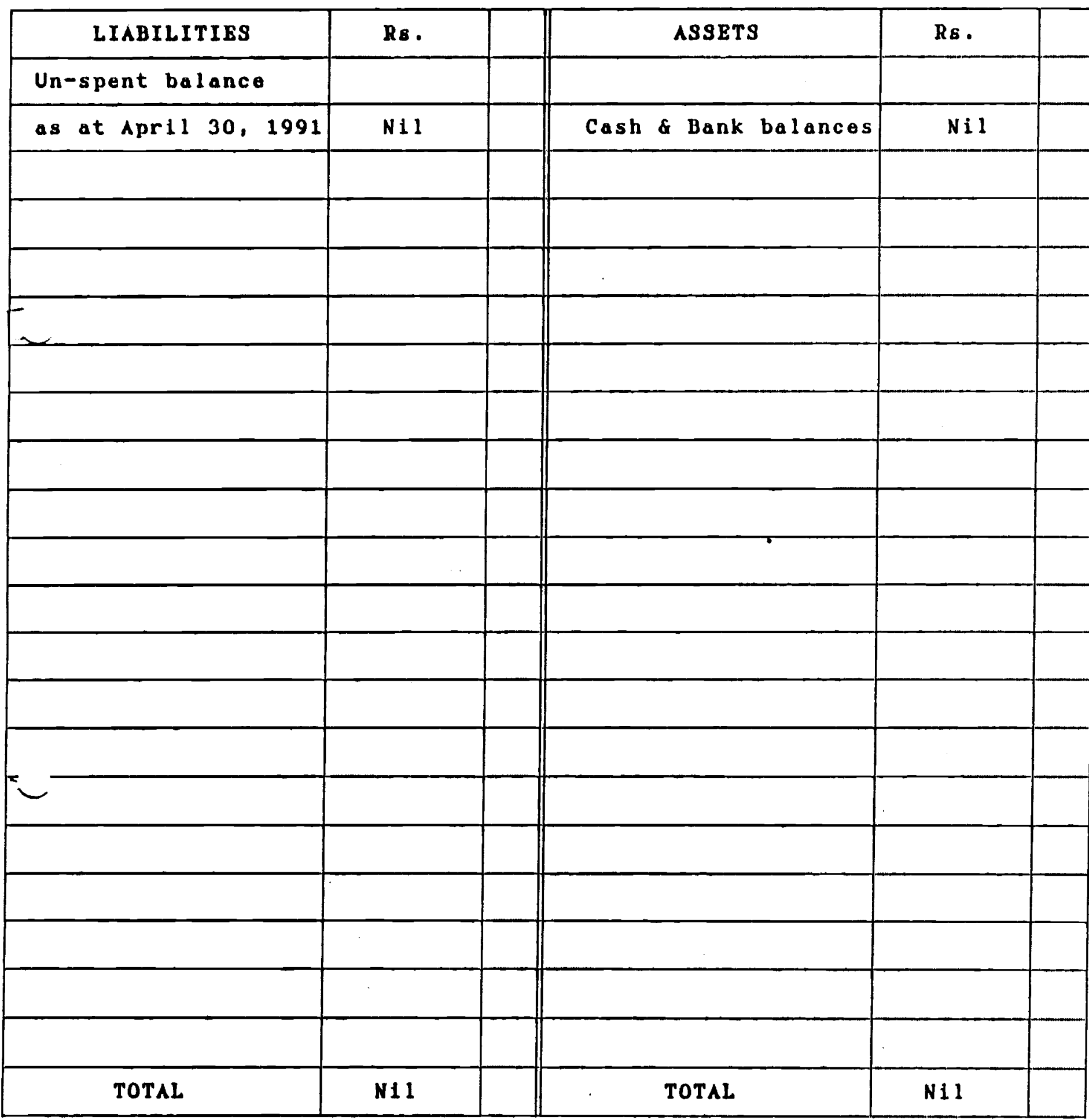

$(+1) d 1$

PROJECT ACCOUNTANT

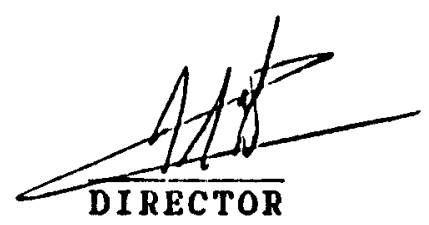




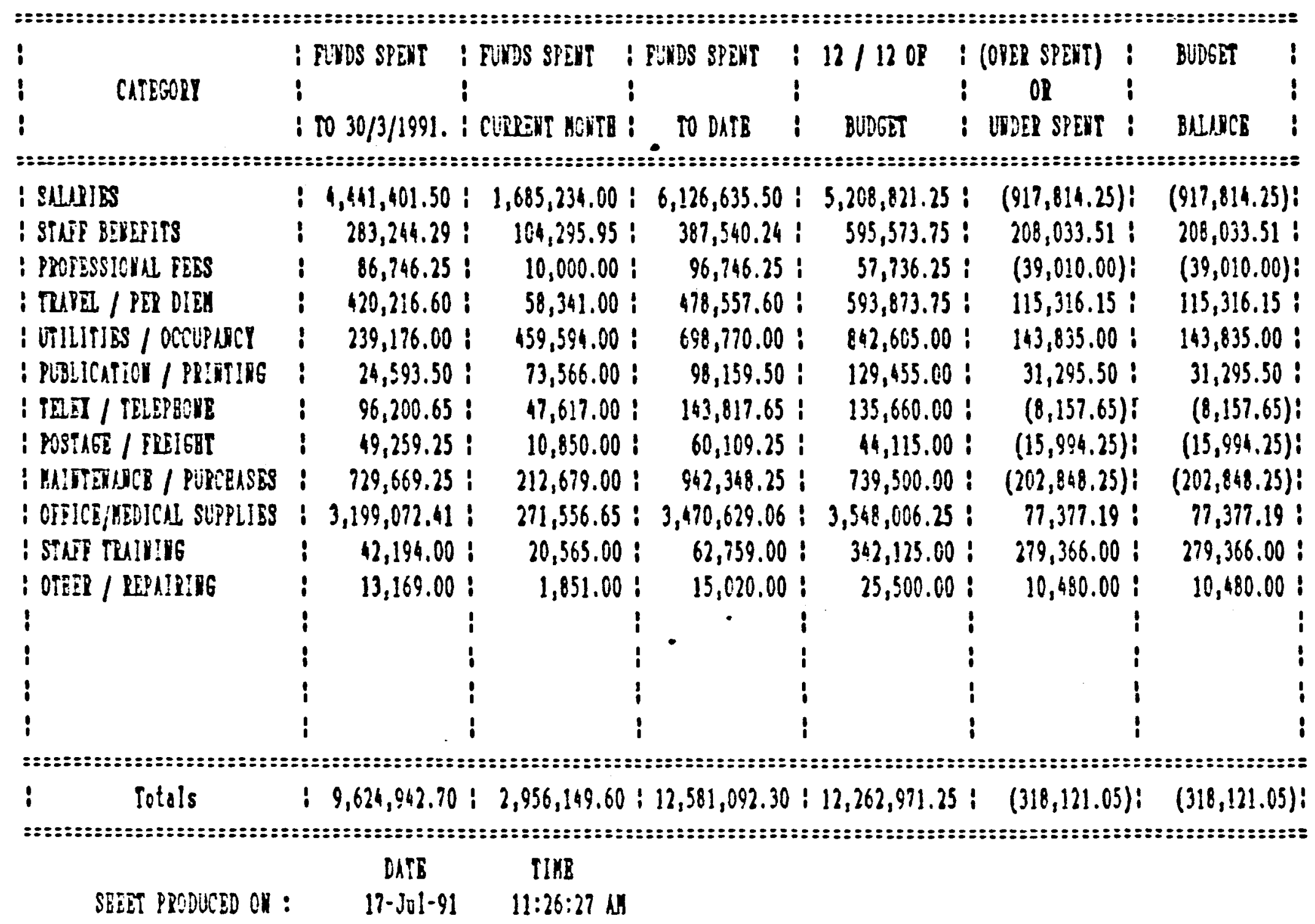




\title{
INSTITUTIONAL DEVELOPMENT
}

\author{
AND \\ PROVISION OF TECHNICAL ASSISTANCE \\ To \\ AFGHAN DEVELOPMENT ASSOCIATION \\ BY
}

THE SALVATION ARMY

PESHAWAR. 


\section{LIST_OF_CONTENTS}

PAGF NO'S

1. INTRODUCTION

1

2. BACKGROUND 2

3. STATEMENT OF AIM 4

4. SECTORAL AREAS OF WORK RELATED TO THE AIM 5

5. SENIOR STAFF ORGANOGRAM FOR EACH SECTOR 6

6. MAJOR TASKS RELATING TO EACH SECTOR 7

7. PAKISTAN PROGRAMME DIRECTORATE 7

8. MARKETING DIRECTORATE

9. FINANCE DIRECTORATE 9

10. ADMINISTRATIVE DIRECTORATE 10

11. DEVELOPMENT DIRECTORATE $• \quad 11$

12. PROVISION OF TECHNICAL ASSISTANCE 12

13. CONCLUSION 15

\section{LIST_OF ANNEXES}

1. TIME TABLE FOR TFCHNICAL ASSISTANCE

2. LONG TERM PLANNING 


\section{INTRODUCTION}

In December 1988, two internal Salvation Army concept papers were written by Captain Ivor $S$. Telfer "Into Afghanistan .... 'lhe Way Forward" and "Into Afghanistan .... and The Way out." The latter of those outlined the basis for the creation ot an indigious Afghan Non-Governmental Organisation (ANGO) trom within the existing Salvation Army Programes in Peshawar.

Since the genesis of the idea of creating an ANGO, much work has ensued towards the preparation for the sustainability of such an ANGO.

This document outlines the ideas behind the creation of the ANGO, - Afghan Development Association (ADA) - together with the organisational planning for ADA and the need for and provision of technical assistance by The salvation army staff in peshawar to the sentor staff of ADA.

It is hoped that this small contribution may give some focus on and some guidelines about the work involved and the technical assistance needed to create an afghan NGO. This process cannot and must not be planned or implemented in too much haste or the venture will be sure to fail.

It remains to be seen whether or not an ANGO is actually viable and sustainable for reconstruction and development work in Atghanistan. However, if this venture should fail, then by studying the cause of its failure, much should be gleaned which would assist other agencies who may be planning such a venture in the future. 


\section{DACRGROUND}

After the preparation of the concept paper of December 1988 outlining the idea of an ANGO - Into Afghanistan ... and 'lhe Way out' - the first area to be investigated was that of capable senior Afghan staff, following which the sectors of work of the ANGO also had to be discussed.

\section{STAFF}

Relating to the staff, Salvation Army has always had a policy of a miniuum number of expatriates on the project. Iherefore the work in Peshawar had developed with senior staff who are afghan and Pakistani with the Director as the only expatriate decision maker. This ensured development of projects and staft at a siullar level and gave a sound basis of practical experience. With on-the-job training in an ad hoc manner, together with suitable Pakistan Institute of Management courses, the senior staff, by being involved in the decision making process, soon developed management techniques and abilities.

This lack of expatriate decision makers has been the key to the present sucess of the creation of an ANGO.

Another factor was the need to prepare the staff to take on responsibilities and to improve qualifications and abilities for their existing tasks. This was effected by sending a few of the senior staff on local courses and by holding more regular and formal planning meetings on the on-going work of the Incone Generation of Vocational Training division.

\section{PROGRAMMES}

In attempting to prepare for the ANGO, in February 1989 it was decided that initially the ANGO would only be involved in Income Generation \& Vocational Training. This decision was taken due to the long term sustainability of an NGO in afghanistan and also due to the technical abilities of the afghan staff involved in the programme.

\section{DEVELOPMENT}

The next consideration was the increasing devolvement of responsiblity and authority to the Income Ceneration d Vocational rraining division in order to prepare thell for life on their own'. 'l'his process commenced in April 1909 and continues to this date. 
On 31st October 1990, a formal Memorandum of Understanding between The Salvation Army and Afghan Development Association was signed, as was the legal constitution of afghan Development Association, thereby finally giving birth to the new agency.

The next steps in this development process and the institutional development were formulated in a meting between Ghulam Jelani Popal (Managing Director - ADA) and Ivor S. Ielfer (Director Salvation Arwy) on 17/10 May 1991. The following is a record of this meeting. 


\section{STATBMENT_OF AIM}

For any organisation to function efficiently, achieve its maximum potential and have maximum impact on its target group, a clear statement of aim is necessary.

According to the Legal constitution of Afghan Development Agency (now Afghan Development Association), the stated aim of the organisation is

"to assist the people of Afghanistan in the rehabilitation of the rural econony by implenenting and establishing various alti-sectoral developuent projects in poor rural areas."

This aim was disected and re-presented as follows

"to assist the Afghan people, whether in the refugee camps or in Afghanistan

in the rehabilitation and development of the rural economy,

by implementing multi-sectoral rehabilitation and development projects and

by establishing and promoting sustainable enterprises.

This aim then formed the guidelines for the remainder of the discussion, the participants ensuring that no activity should be suggested or planned which did not correspond to the agreed ain of Afghan Development Association (ADA). 


\section{SECTORAL AREAS_OF WORK RELATED TO THE AIM}

In stating the AIM, it is vital for the organisation to ensure that none of its activities is un-related to its aim. This clarifies the areas of work and thereby prevents the creation of a 'multi-headed monster' which wishes to pull in various directions at one and the same time. It is imperative that, in development, an integrated approach is taken and by following the aim and 1 isting the sectors of work related to that aim, the ANGO will not be led into other areas either by itself or by donors.

The following diagram shows the areas of work planned for ADA and their inter-relationship.

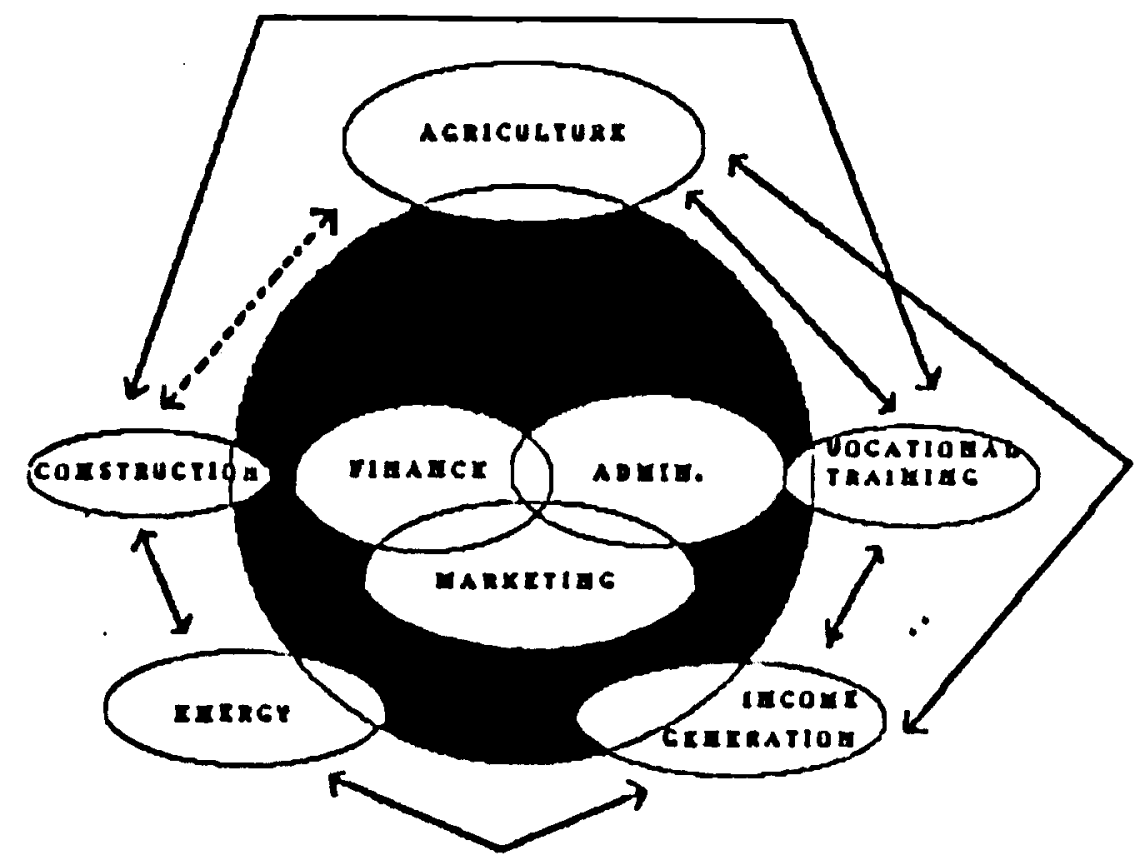

YORK DLAGRAM EOR RELATIONSHIP BETWEEN SECTORS

Prioritisation of these work areas is as follows

1. Administration

2. Finance

3. Marketing

4. Agriculture

5. Income Generation

6. Vocational Training

7. Construction

8. Energy 


\section{SPIIOR STAFF ORGANOCRAM_FOR EACIISECTOR.}

Having established and prioritised the sectors of work, the next need is to ensure that competent senior staff are available for management of each sector.

The undernoted diagram was completed and shows the situation which should be ained at for ADA. Obviously, there will be various steps to achieve this ideal set-up and this will commence with an iuternal wove of offices and some personnul at the beginning of June 1991. (This has now been effectively completed.)

As can be seen frow the Work Diagram, the Work Areas have not all been reflected as separate departments in the organogram e.g. the Vocational Training and Income Ceneration have been uerged under the Pakistan Programe Director while the Central Alghanistan Director will be responsible for all sectors of work in his geographical area.

To assist in standardisation of programmes and to ensure there is no duplication or wrong standards used, the Development Directorate will be convened to look at the results of surveys and to form proposals to ensure that the same agricultural. construction standards are maintained in all programmes, irrespective of their geographic location.

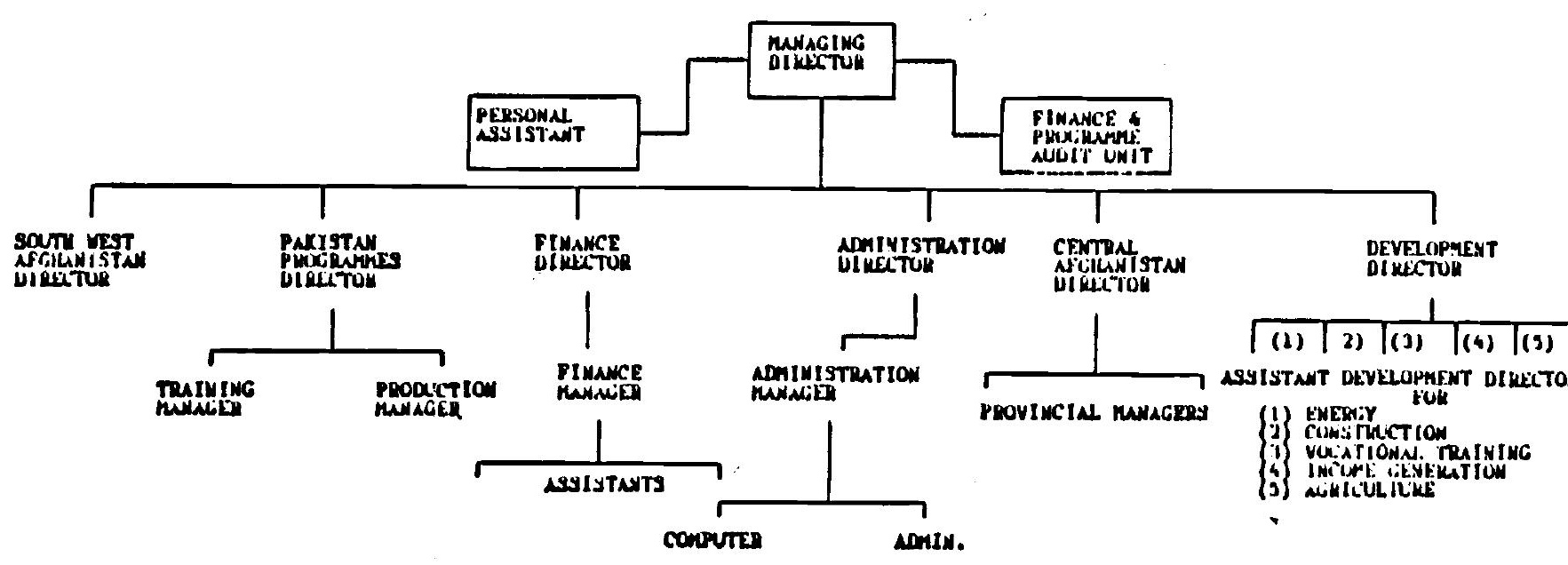




\section{MAJOR TASKS RELATING TO_EACH SECTOR}

In a further attempt to clarify the implementation steps necessary to achieve the aim of $A D A$, it was decided to list ald prioritise the major tasks for each sector. This not only brings individual focus for each sector but also assists in the relevant provision of technical asistance to the senior staff of each sector. Also, by the documentation of an organograu, the structure, work flow and decision inaking are clearly shown to both management and staff.

\section{PAKISTAN PROGRAMME DIRECTORATE}

\section{PRIORITY NO. 1 INCOME GENERATION}

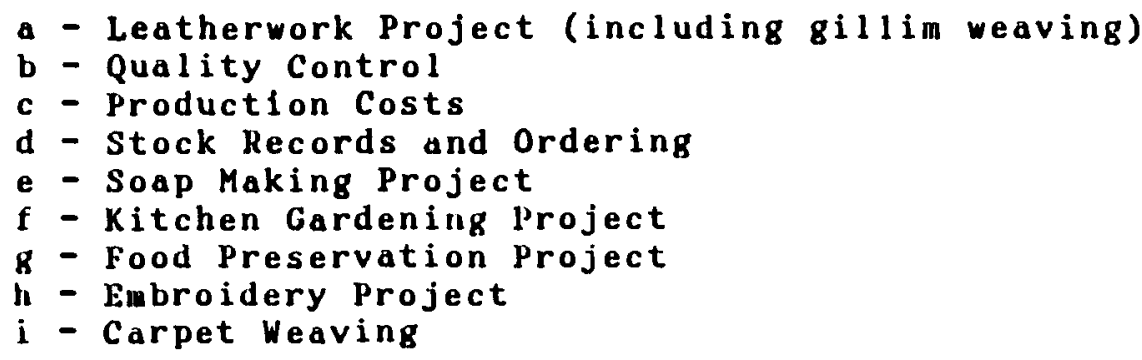

\section{PRIORITY NO. 2 VOCATIONAL TRAINING}
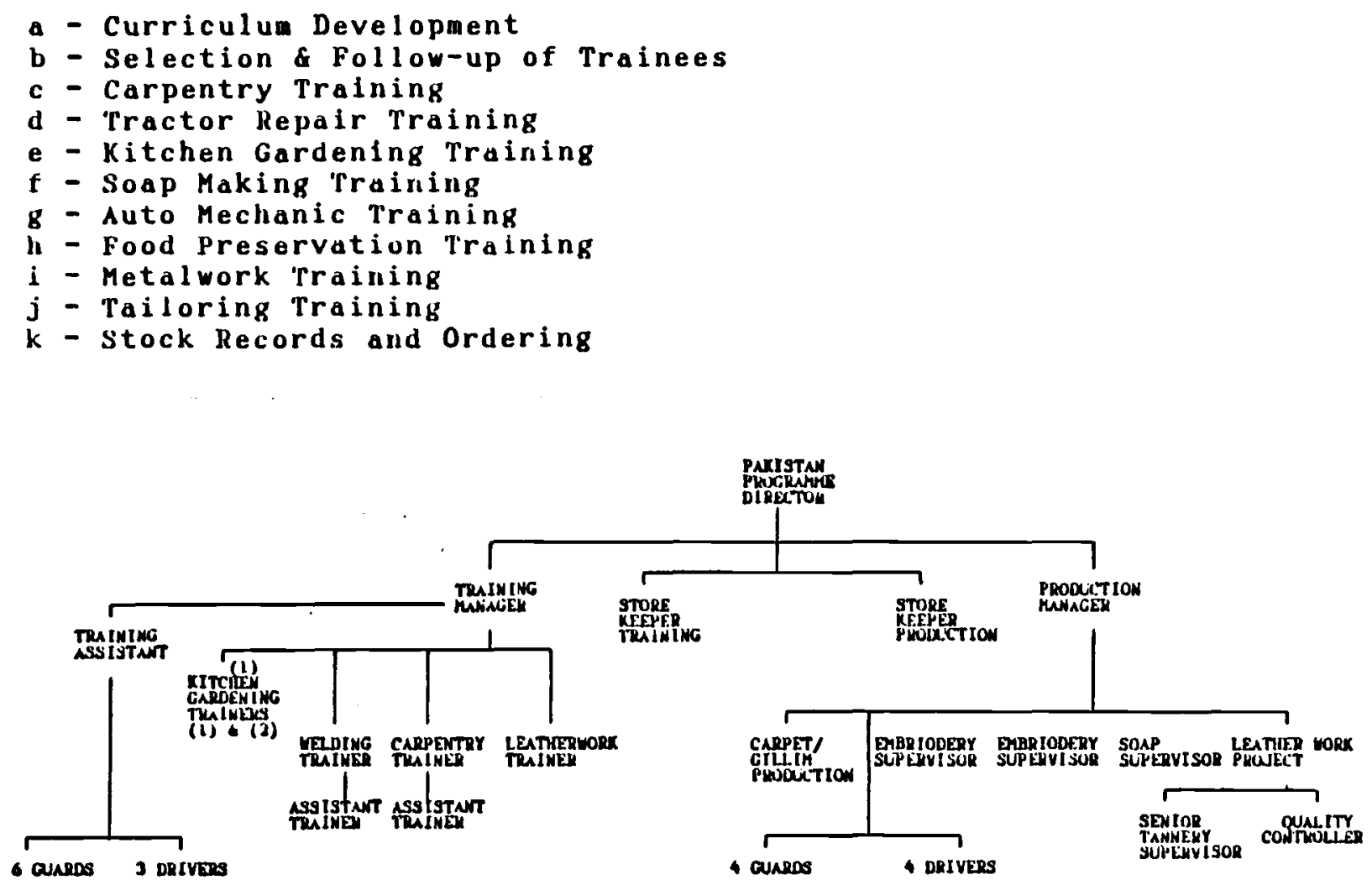


\section{MARKFTING DIRBCTORATB}

PRIORITY NO, 1 MARKETING COSTS

a - Production costs

b - Overhead Costs

c - Profit Margin - Why?

- What?

d - Cost to Market Goods

e - Wholesale Cost

f - Retail Cost

PRIORITY NO. 2 SALES PROMOTION
a - Quality
b - Price lists
c - Brochures
d - Designs
e - Contacts
f - Exports
g - Fxhibitions
$h$ - Research and Planning

PRIORITY NO. 3 STOCK OF FINISHED COODS

PRIORITY NO. 4 MURREE SHOP

PRIORITY NO. 5 PESHAWAR SHOP

PRIORITY NO. 6 QUETTA SHOP

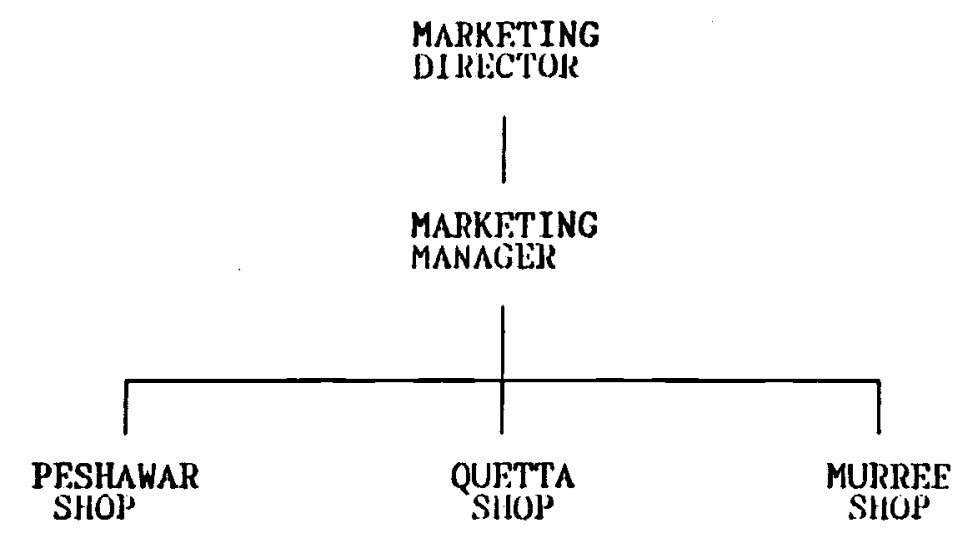




\section{FINANCE DIRRCTORATE}

\section{PRIORITIES AS UNDERNOTED}

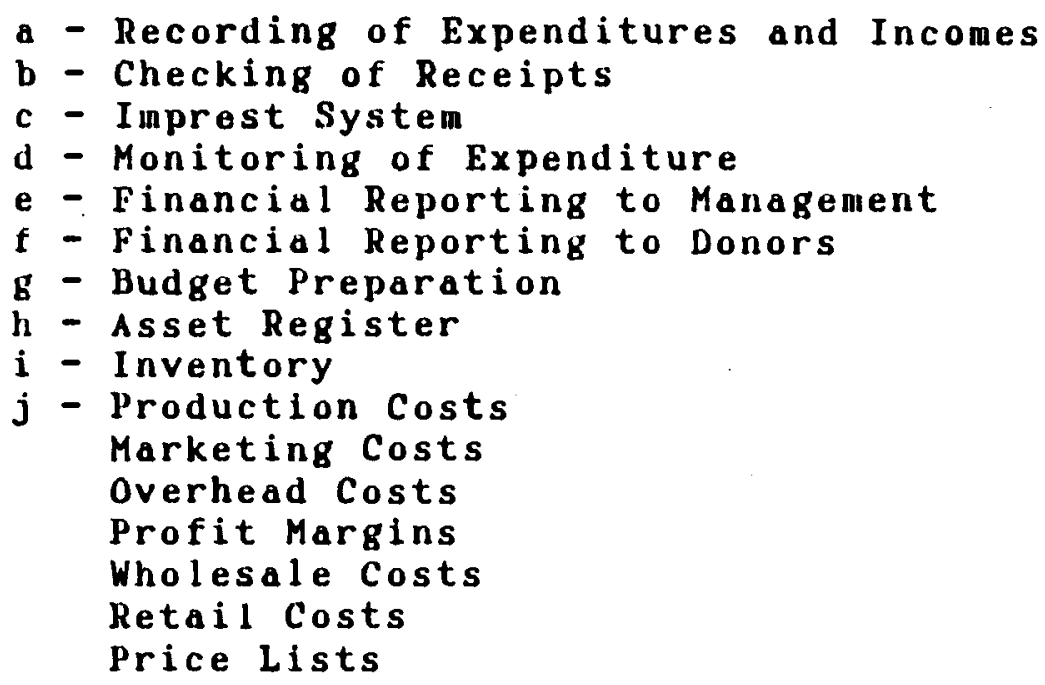

FINANCE

DIREC'TOR<smiles>CCCC</smiles>

FINANCE

MANAGER

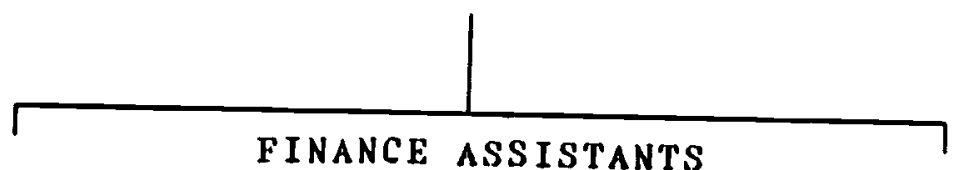

FINANCE ASSISTANTS 


\section{ADMINISTRATIVE DIRFCTORATE}

PRIORITIES AS UNDERNOTED

a - Office Procedures and Policies on all components

$b$ - Central Information flow including Logistics

c - Filing including Personnel Records

d - Computer Programing and Data Input

e - Reporting to Donors

f - Purchasing of All Assets

g - Staff Recruitment and Facilitation of Recruitment

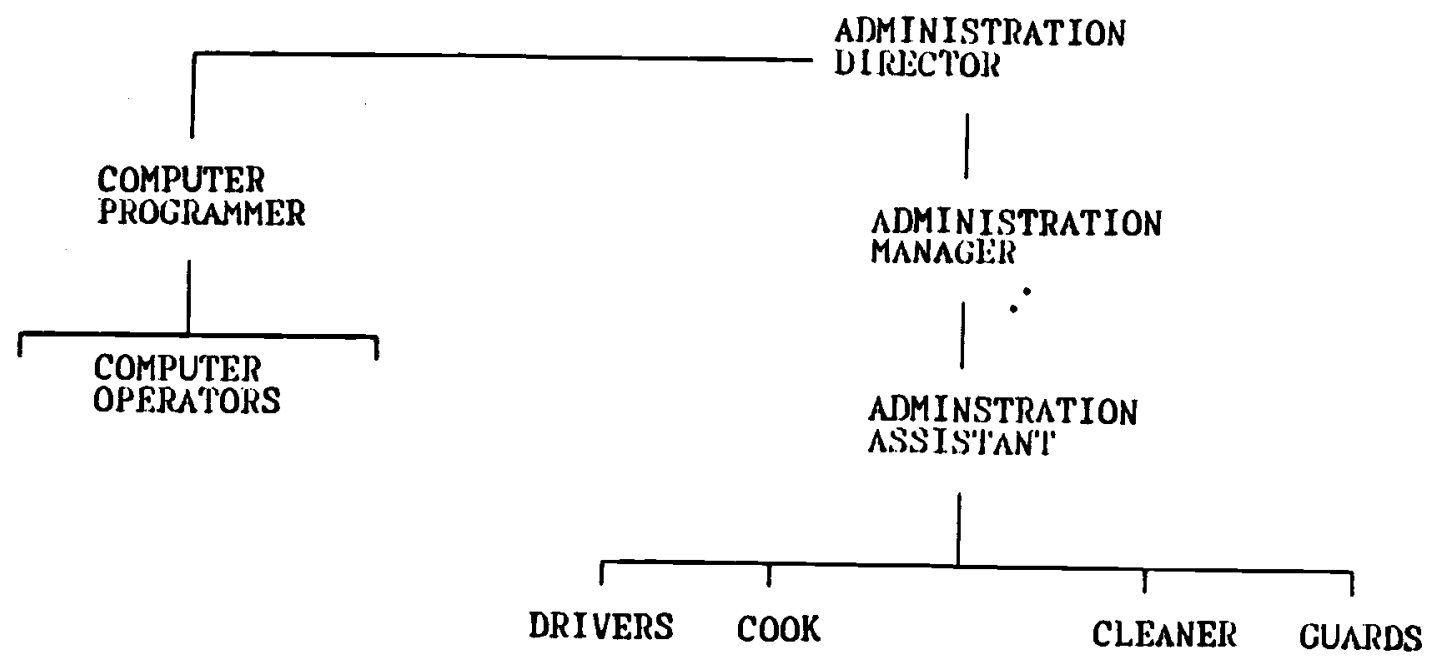




\section{DEVELOPMENT DIRECTORATE}
a - Surveys
b - Planning
c - Proposals
d - Monitoring
e - Technical Assistance to Projects
f - Self Evaluation of Projects

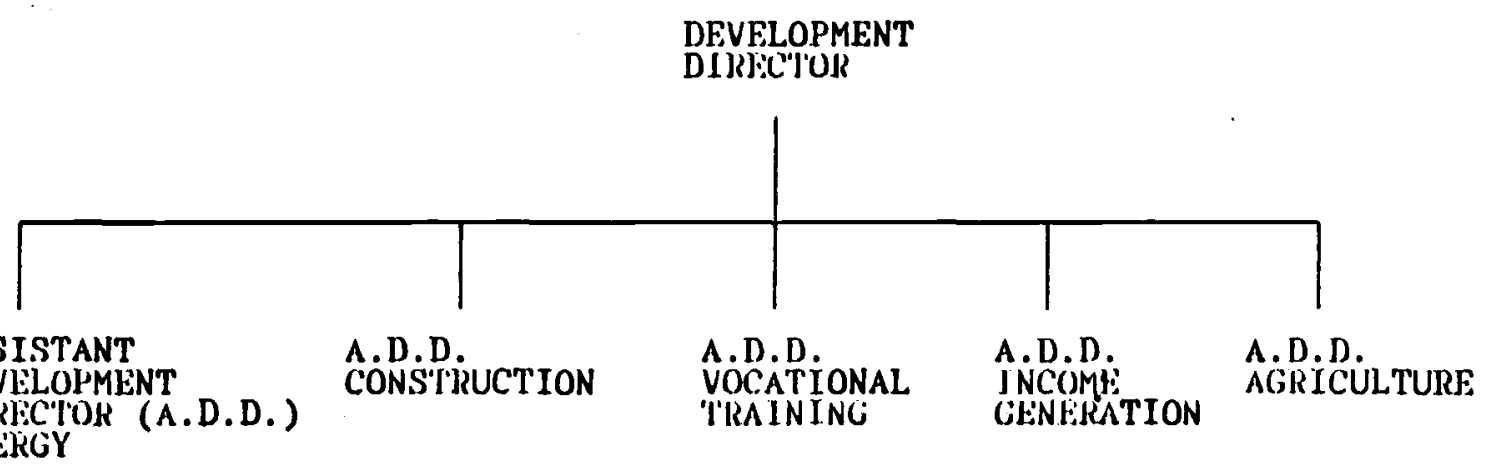




\section{PROUISION OF TRCHNICAL ASSISTANCE}

The last major step is the provision of relevant technical assistance to key personnel.

Having an aim, sectors of work, organograms and task lists without capable staff, will not make the organisation function. It is therefore a priority to ask the following questions : -

TECHNICAL ASSISTANCE
a) For whom?
b) By Whom?
c) About what?
d) When?

ABBREVIATIONS USBD IN THIS SBCTION ARE EXPLAINED AS FOLLOWS

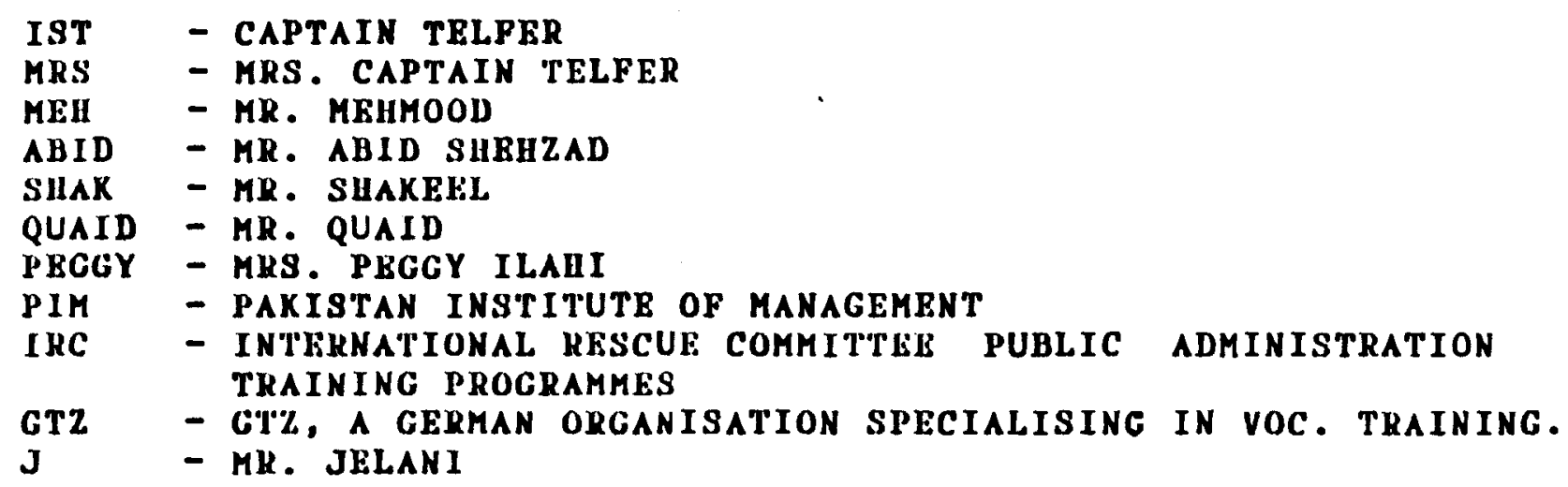

Each senior staff member was provisionally assessed and as is mentioned later, an actual assessuent will be completed by both providor and providee to ensure relevant quality technical assistance is both given and received.

\section{SUBJECT}

\section{PROVIDER MONTH}

\section{JELANI}

1. PERSONAL ADMIN. SYSTEMS (SCHEDULES, DIARY ETC)

2. FINANCE

3. BOARD MEETINGS

4. COMPUTER

5. ENCLISH

6. PERSONNEL MGT.

7. DONOR RELATIONS

$\begin{array}{ll}\text { IST } & \text { JUNE } \\ \text { IST/ABID } & \text { JULY } \\ \text { IST } & \text { JUNI: } \\ \text { QUAID } & \text { AUG/SEPT } \\ \text { PEGGY } & \text { AUC/SEPT/OCT } \\ \text { P.I.M. } & ? \\ \text { IST } & \text { CONTINUOUS }\end{array}$


1. PRODUCTION PLANNING

2. HEPURT WHITINC

3. FINANCE

4. COMPUTER

5. ENCLISII

6. MANAGEMENT OF VOC.TR.PROC.

7. MANACEMENT

U. ADMINISTRATION

\section{SULAIMAN}

1. QUALITY CONTROL

2. UISPLAY

3. SALFS JROMOTION

4. STOCX

5. YINANCE

6. RLSEARCh \& PLANING

7. FNGLISH

U. ADMINISTRATION

9. MANACEMLENT

10. COMPUTER

\section{SAMAD}

1. planning

2. REPORT WRITING

3. MANACEMENT

4. PINANCE

5. ADMINISTRATION

o. PLRSONNHL MANACEMENT

\section{SIDDIQUE}

1. CASH BOOK

2. LEDCEHS

3. VOUCHERS

4. IMPRES'I SYSTEMS

5. HaLANCINC

6. CAsII Flow

7. MONIHLY MONITORING

U. DONOR HEPORTINC

9. payscales

10. IUDCE'T ING

$\begin{array}{lc}\text { IST/J } & \text { JULY } \\ \text { MLII } & \text { JUNJ: } \\ \text { IHC } & ? \\ \text { AUID } & \text { AUC } \\ \text { QUAID } & \text { JUNE } \\ \text { MEM } & \text { JUNE } \\ \text { IHC } & ? \\ \text { C'I\% } & \text { SLPT } \\ \text { IS'T/MEM } & \text { SEPT } \\ \text { MEM } & \text { JULY }\end{array}$

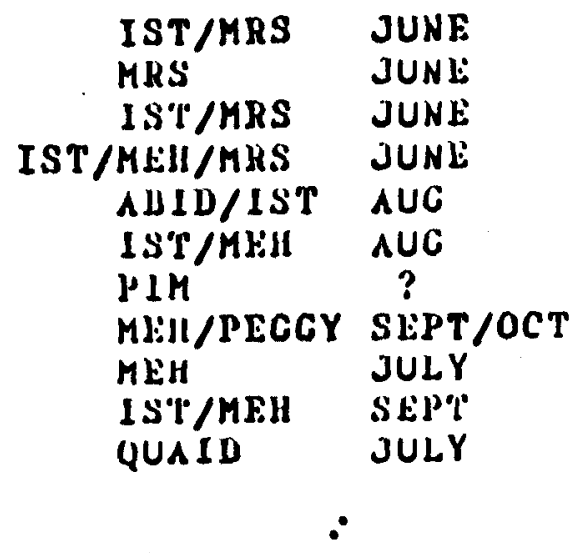

MFH

INC

MEH

ME:H

$A \perp \perp D$

Mill

MI:J

$I R C$

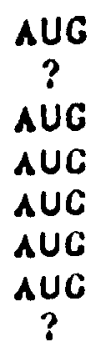

ABID

JUNE

ADID

JUNE:

AHIV

JUNE

AIID

JUNE

AHID/IST JUNL:

ALID/IST JUNE

ABID/IS' JUNE

ALID/IST JULY

AHID/IST JULY

IST/ABID JULY 


\section{SALAAM}

1. ENGLISH

2. FILING

3. OFFICE MANAGEMENT

4. PURCHASING/G.O.P. DEALING

5. COMPUTER

6. REPORT WRITING

$\begin{array}{lc}\text { SHAK } & \text { JUNE } \\ \text { COURSES } & ? \\ \text { SHAK } & \text { JUNE } \\ \text { SHAK/MEH } & \text { JUNE } \\ \text { IRC } & ? \\ \text { SHAK/MEH } & \text { JUNE } \\ \text { SHAK/QUAID } & \text { JULY } \\ \text { COURSES } & \\ \text { MEH/IST } & \text { AUG } \\ \text { IRC } & ?\end{array}$

MR. HASSAN

1. SEE MR. SULAIMAN'S LIST AND INCLUDE MR. HASSAN WHERE POSSIBLE DURING THIS TECHNICAL ASSISTANCE

2. ENGLISH

3. ADMINISTRATION

4. FINANCE

5. BASIC PRINCIPLES OF MARKETING

6. DEVELOPING MARKETING SKILLS

\section{AJMAL}

1. ADMINISTRATION

2. PLANNING

3. MONITORING

4. FINANCE

5. REPORTING

6. ENGLISH

7. MANAGEMENT

8. COMPUTER

$\begin{array}{lc}\text { SHAK } & \text { JUNE } \\ \text { SHAK } & \text { JUNE } \\ \text { ABID } & \text { JUNE } \\ \text { PIM } & ? \\ \text { PIM } & ?\end{array}$

$\begin{array}{lc}\text { SHAK } & \text { JUNE } \\ \text { MEH/IST } & \text { JULY } \\ \text { IRC } & \text { ? } \\ \text { MEH/IST } & \text { JULY } \\ \text { ABID } & \text { AUG } \\ \text { MEII } & \text { AUG } \\ \text { SHAK } & \text { JUNE } \\ \text { COURSES } & ? \\ \text { MEH } & \text { AUG } \\ \text { IRC } & ? \\ \text { QUAID } & \text { AUG }\end{array}$

It was agreed that the following steps should be taken :

a) Captain Telfer will procure timetables and course contents from IRC, SCF(UK), ISRA and any other appropriate training institute (including P.I.M.) and then formulate the courses and the dates for each student as above list.

b) Specific Training Days will be arranged when the staff have the opportunity to concentrate for that day on an in-house training course organised and conducted by one or more of the providers of technical assistance. Captain relfer and Mr. Mehmood will work on this. 
c) There will be a progress review meeting between Mr. Jelani, Mr. Mehmood. Mr. Abid and Captain Telter on 4th. July 1991 and then probably a larger review meeting in early september for the next period of technical assistance.

d) Forms for assessment of the quality of technical assistance given and received will be prepared for completion by both the providor and the providee.

\section{CONCLUSION}

The ain of development is to enable the people to care for and develop themselves, with decreasing assistance from external sources.

Here in the Afghan context, this external assistance will be necessary for a considerable period of time due to the infrastructural damage in afghanistan, not to mention the health, education and agricultural dificulties.

It is important to note that the process which has been referred to in this document is not the only way forward. Aid, rehabilitation and development projects need to be implemented in Afghanistan and whoever is willing to work on behalf of the Afghan people, would be encouraged. To assume or propagate the idea that Afghan NCOs exclusively should implement aid work is not only short sighted but is potentially hariful to the aid scenario and delivery of assistance to the afghin people.

The rule to be remembered is 'make the best possible use of the available resources' whether expatriate or afghan or lost country.

What has been achieved by ADA/Salvation Army is only one way of making the best use of the available resources. There are many other ways. All are necessary if Afghanistan is to be habitable in safety for the families of today and tomorrow.

By referring to the foregoing record of the planning related to ADA, it is hoped that lessons will be learned which will be of use to others who feel they should follow this route. If ADA proves to be sustainable, then obviously we have 'got it right'. If not, others can learn from our mistakes.

It is our hope that this planning and technical assistance will enable the Afghan staff of ADA to efficiently and sensitively assist their fellow Afghans, thereby"making the best possible use of the available resources." 
TIME TABIE FOR TECHNICAI ASSISTANCE

\begin{tabular}{|c|c|c|c|c|c|c|c|}
\hline MAME & JUNB & \begin{tabular}{l|l} 
JULY & \\
\end{tabular} & AUGUST & SBPTEMAER & OCTOBER & NOVEMBER & DBCEMBER \\
\hline $\begin{array}{l}\text { Mr. Ghulag Jaland, } \\
\text { Magazlaz Director: }\end{array}$ & $\begin{array}{l}\text { P.A.S by IST } \\
\text { B.A. by IST }\end{array}$ & 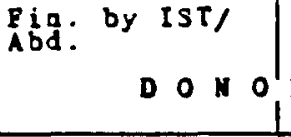 & 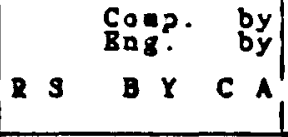 & 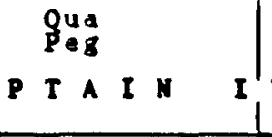 & S. T B & F $8 \mathrm{R}$ & \\
\hline Mr. Mazir. Prog: Director. & 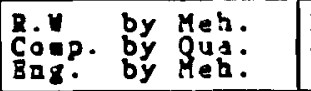 & $\begin{array}{l}\text { Prodp by IST/ } \\
\text { Jel: by Meh }\end{array}$ & Fla. by Abd. & 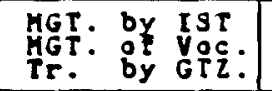 & & & \\
\hline Mrosulalagad & 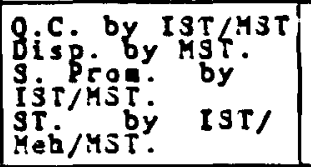 & $\begin{array}{l}\text { Ada by Meb. } \\
\text { Coup by Qua. }\end{array}$ & 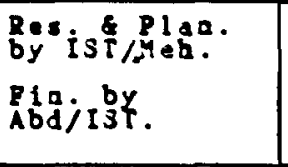 & $\begin{array}{r}\text { Mat: by IST/ } \\
\text { Bager: }\end{array}$ & by $P=8$ & & \\
\hline Mreatrail Akg. Director & & & 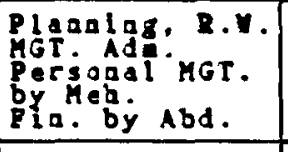 & & & & \\
\hline $\begin{array}{l}\text { Mr. Siddique, } \\
\text { Píanca Maderer. }\end{array}$ & 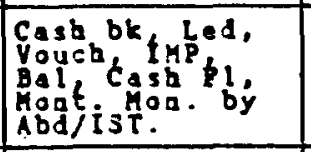 & 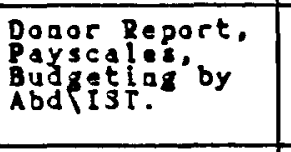 & & & & & \\
\hline 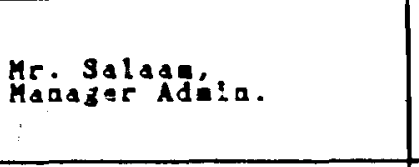 & 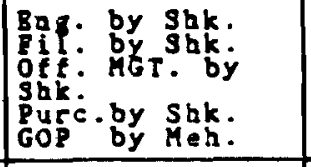 & Coup. by Qua. & R.V by Meh. & & & & \\
\hline 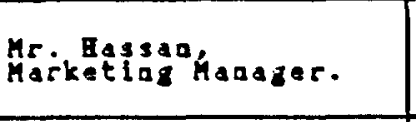 & $\begin{array}{l}\text { Baz. by shk. } \\
\text { Ada. by shk. }\end{array}$ & $S$ B B & MR. SULAIMAN A. & INYOLVB In & OST OP TEESB AC & IVITIBs & \\
\hline Mro Ajealigar. & $\begin{array}{l}\text { Ada. by sak. } \\
\text { gaz. by shk. }\end{array}$ & PL. by Meb/IST & 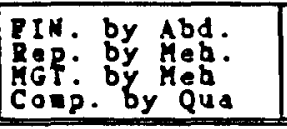 & & & & \\
\hline
\end{tabular}

ABBREVIATLONS USED ABOVB ARS BXPLATNBD AS UNDER:

\begin{tabular}{|c|c|c|c|c|c|c|}
\hline 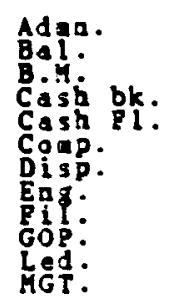 & 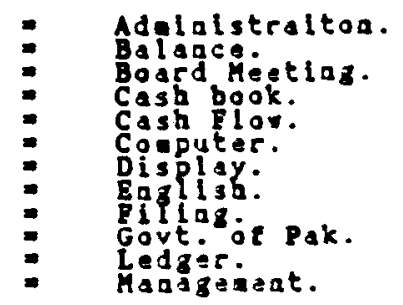 & 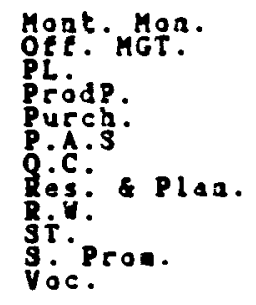 & 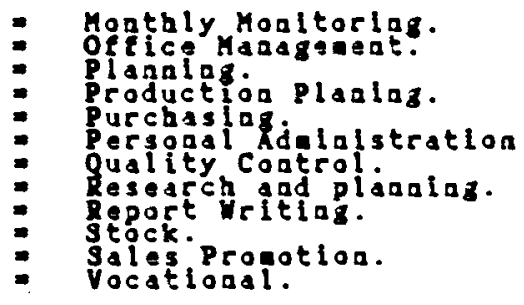 & systea. & $\begin{array}{l}\text { Abd: } \\
\text { ist } \\
\text { Jel. } \\
\text { Meb: } \\
\text { Mst: } \\
\text { Peg: } \\
\text { gua: } \\
\text { Suk. }\end{array}$ & 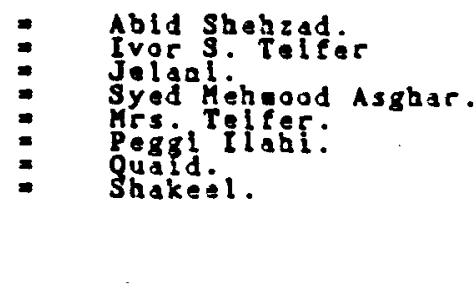 \\
\hline
\end{tabular}


LONG TERM PIANNING

\begin{tabular}{|c|c|c|c|c|}
\hline & MULTI - SECTORAL PHOJECTS & REPUGE & REHABILITATION & DEVELOPNBNT \\
\hline 1 & AGRICULTUHE & & & \\
\hline a & seed fortliser & & $x$ & \\
\hline b] & Karaz canel cloaning repalr & & $\mathbf{x}$ & \\
\hline c & Machanisation & & $\mathbf{x}$ & $x$ \\
\hline d & Ne-torestation & & $x$ & $\mathbf{x}$ \\
\hline$\bullet$ & Training of farmers in now techniques & & $\mathbf{x}$ & $\mathbf{x}$ \\
\hline$t$ & Agrlcultural Credits & & $x$ & $x$ \\
\hline 2 & VOCATIONAL THAIMING & & & \\
\hline$a$ & Leatherwork & $\mathbf{x}$ & $\mathbf{x}$ & \\
\hline b & Carpentry & $x$ & $x$ & \\
\hline c] & Mavonry & & $x$ & \\
\hline d) & Iractor Nepalr & $x$ & $x$ & $x$ \\
\hline - & Taltorlng & $\mathbf{x}$ & & \\
\hline t & Auto Hepalr & $\mathbf{x}$ & $\mathbf{x}$ & \\
\hline c] & Nltchen gardenlng & $x$ & $x$ & $x$ \\
\hline n) & rood preservation & $x$ & $x$ & $x$ \\
\hline i) & Sonp Haklng & $x$ & $x$ & $x$ \\
\hline 3 & INCOHE GKNERATION & & & \\
\hline 4 & Leatlior work & & & $x$ \\
\hline D] & Enbrotuery & $x$ & & $x$ \\
\hline c & Carpet & $\mathbf{x}$ & & $x$ \\
\hline d & Soap & $x$ & & $x$ \\
\hline 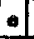 & Kitchen gardening & $x$ & $x$ & $x$ \\
\hline$t$ & rood preacervation & $x$ & $x$ & $x$ \\
\hline g & Poultry Faraing & & & $x$ \\
\hline h & Seall bus Iness developeent & & $x$ & $x$ \\
\hline 1 & Marketing & $x$ & $x$ & $x$ \\
\hline 4 & COMSTRUCTION & & & \\
\hline$a$ & Mondy & & $\mathbf{x}$ & $x$ \\
\hline b) & Seall bridges & . & $\mathbf{x}$ & $\mathbf{x}$ \\
\hline c) & Schools & & & \\
\hline d] & Modtcal faclittlos & & $\mathbf{x}$ & $x$ \\
\hline 5 & ENBUCY & & & \\
\hline a & Hydru-aloctric & & & $x$ \\
\hline b] & Solar & & & $x$ \\
\hline c. & Ind & & & $x$ \\
\hline d] & Collservation & & & $x$ \\
\hline
\end{tabular}




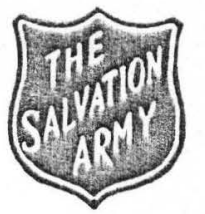

THE SALVATION ARWY

Afghan Refugee Assistance Project

PAKISTAN

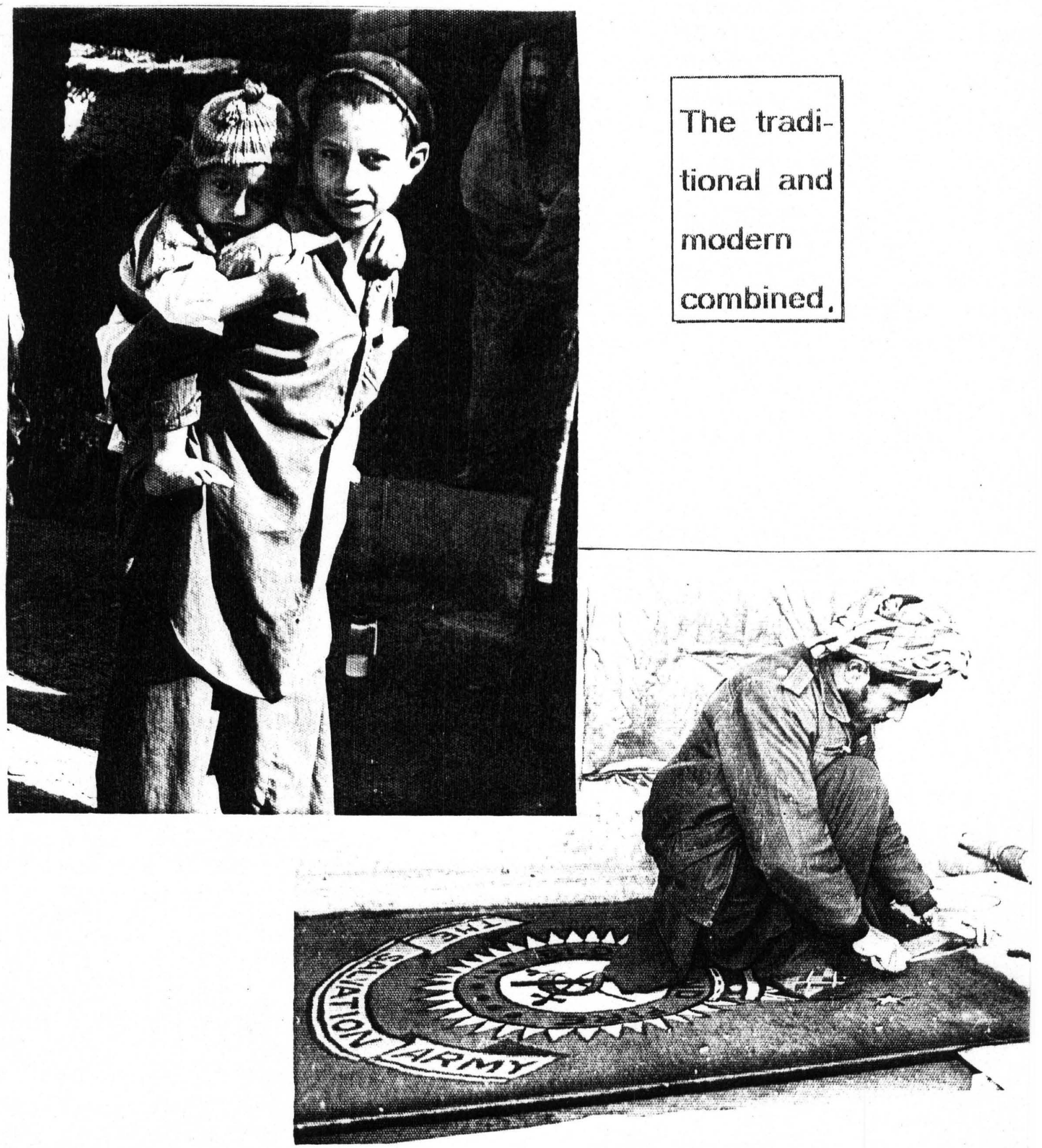

